九州大学学術情報リポジトリ

Kyushu University Institutional Repository

\title{
Fusuline Zonation of the Lower Permian Sakamotozawa Series
}

Kanmera, Kametoshi

Faculty of Science, Kyushu University

Mikami, Takahiko

Department of Earth Sciences, Yamaguchi University

https://doi.org/10.5109/1543635

出版情報：九州大學理學部紀要：Series D, Geology. 16 (3)，pp.275-320，1965-11-20. Faculty of Science, Kyushu University バージョン：

権利関係 : 


\title{
Fusuline Zonation of the Lower Permian Sakamotozawa Series
}

\author{
By \\ Kametoshi KANMERA and Takahiko MiKAMI
}

\begin{abstract}
This paper is concerned primarily with the description of the fusulinaceans and the zonation of the type Sakamotozawa Formation of the Kitakami massif, which is the type sequence of a comprehensive biostratigraphic unit, the Sakamotozawa Series, of the Lower Permian of Japan.

In the description of species one new species is established and other already known species are revised or commented.

The Sakamotozawa Formation contains varied fusuline faunas that permit its division into five zones, each of which is defined by a particular assemblage of species. They are the Zellia nunosei and the Monodiexodina langsonensis-Nipponitella explicata zone in the Lower Subformation, and the Pseudofusulina vulgaris (s.l.), the P. fusiformis and the $P$. ambigua zone in the Upper. Further subdivision is also possible on relatively short-ranged species. There is a remarkable faunal change at the unconformable boundary between the two subformations. The lower two zones are accompanied with species of Paraschwagerina (s.s.), P. (Acervoschwagerina), Rugosofusulina and Quasifusulina, while the upper three zones are characterized by predominant occurrence of species of Pseudofusulina and are associated with species of Schwagerina and Nagatoella. Species of Paraschwagerina (s.s.) and P. (Acervoschwagerina) do not abundantly occur, but they are confined to the Lower Subformation. A species of Zellia has a short stratigraphic range and defines the lowest zone in the formation. A species of Pseudoschwagerina (Robustoschwagerina) ranges up into the Upper Subformation. In conclusion some remarks are given to the zonal correlation of the Lower Permian between the selected areas in Japan and other provinces.
\end{abstract}

\section{Contents}

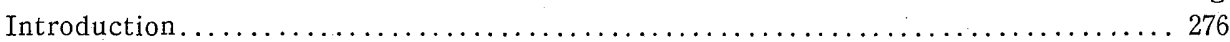

Description of species.......................................... 277

Zonation of the type Sakamotozawa Series ............................ 309

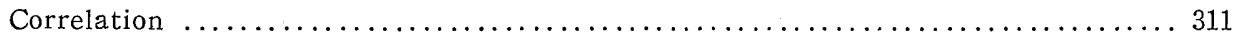

A. Correlation within the Japanese Islands $\ldots \ldots \ldots \ldots \ldots \ldots \ldots \ldots \ldots \ldots \ldots \ldots \ldots \ldots \ldots$

B. Some remarks on the definition of the Sakamotozawa Series . . . . . . . . 313

C. Remarks on international correlation.............................. 314

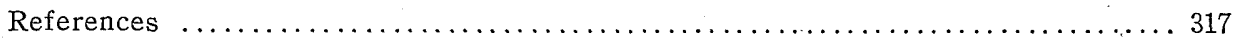

Manuscript received July 10, 1965.

T. Mikami: Department of Earth Sciences, Yamaguchi University, Yamaguchi. 


\section{Introduction}

The Lower Permian in Japan is comprehensively called the Sakamotozawa Series. The type section of the series is in the Sakamotozawa Formation in the Kesen district, southern part of the Kitakami region, Northeast Japan.

The name of the Sakamotozawa Formation or Series was at first introduced by ONUKI $(1938,1939)$ who established the stratigraphy of the Upper Carboniferous and Permian strata of the Kesen district in a systematic way. Since then the district has been visited by a number of geologists and palaeontologists, of whom MinATO (1941, 1942), MoRikawa (1953), Minato et al. (1954, 1959, 1965), YamadA (1955) and ONUKI (1956) have made remarkable contributions to our knowledge of the stratigraphy of the Permian strata.

The formation contains large and varied fusuline faunas that are of particular importance because they provide a foundation of stratigraphic division and zonation of the Lower Permian as a reference succession in Northeast Japan. The palaeontological studies of fusulinaceans were undertaken by HANZAWA (1938, 1939), TORIYAMA (1952), FujImoto (1956) and MorikAw A (1952a, b). Through these works of stratigraphy and palaeontology it has been clarified that the lower part of the formation is roughly within the "Zone of Pseudoschwagerina" and the upper part belongs to the "Zone of Parafusulina".

In fact, more than forty species of the Fusulinaceae were hitherto recorded by authors from the type and adjoining areas, but about two-thirds of them were only listed and included a large number of undetermined species. Zonation and approximate correlation of the formation were attempted by some authors, but there has been still uncertainty about the stratigraphic distribution and assemblage of species in the type sequence itself, on which the zonation should be based. The reason for this situation may be partly in that most of the stratigraphical and palaeontological studies were made separately from each other and often failed to denoting the exact stratigraphic position of the obtained fossils and partly in that many of the fossils were of unfavourable preservation and have not been accurately described.

Fusulinaceans are most reliable for the zonation and correlation throughout the Permian strata in Japan. In recent years our knowledge has greatly advanced in Southwest Japan as regards the biostratigraphic classification based on fusuline species and the correlation of the Permian formations between separated areas. In spite of the many works mentioned above, the available biostratigraphic data in the type Sakamotozawa Formation have not been so sufficient and so reliable as to allow us a definite conclusion about the correlation between the Kitakami region and Southwest Japan. Thus the restudy in the light of up-to-date biostratigraphy has been needed.

For a precise definition and an accurate correlation of biostratigraphic units the stratigraphic subdivision of the type section and the palaeontological description of the species concerned are indispensable. The description of stratigraphy has been given in a companion paper entitled "Succession and Sedimentary Features of the Lower Permian Sakamotozawa Formation". This paper is, therefore, concerned primarily with descriptions of the Fusulinaceae and the zonation of the type Sakamotozawa. 
Series. In addition a zonal correlation of the Lower Permian between the selected areas in Japan is attempted. Problems of international correlation may be also commented to some extent.

Preservation of the material.-Fusuline fossils from the Kitakami region are in general extremely poor in preservation, having been strongly deformed, as exemplified by those monographed by TORIYAMA (1952) and MoRIKAWA (1952a, b). The specimens. were more or less elongated in many cases along the axis of coiling of the shell, as they had been embedded usually almost parallel to a bedding plane. Thus the poor preservation of the material prevented the precise identification of species and gave a great difficulty to the zonation of the Permian strata in the Kitakami region. The specimens obtained by us are similarly deformed, and some of them are almost completely replaced by secondary mineralization. About two-thirds of the material are, however, sufficiently well preserved for identification.

Collecting locality. - The material for this study came from the Sakamotozawa area and the adjoining Nagaiwa area. For the geographic and stratigraphic positions of collecting localities the reader may refer to the map and profile of Figs. 1 and 2 in the preceding companion paper and Fig. 3 of this paper. The identified species are listed in Table 1 referring to the localities.

Repository.-The specimens described in this paper are kept in the Type-Specimen Room of the Department of Geology, Faculty of Science, Kyushu University, Fukuoka. The register-numbers of the specimens are indicated in the systematic part of this. paper and those of the figured specimens are given also in the explanations of plates.

Acknowledgements.-We take pleasure in recording again our sincere appreciation. to the persons to whom we acknowledged in the preceding companion paper. On this. occasion our particular thanks are extended to Prof. Ryuzo ToRIYAMA of Kyushu University who gave us valuable advice and offered the privilege of free use of his. private library.

\title{
Description of species
}

Superfamily Fusulinacea von MöLLER, 1878

Family Ozawainellidae Thompson and FosTer, 1937

Genus Toriyamaia KANMERA, 1956

Type-species.-Toriyamaia laxiseptata KANMERA, 1956

\author{
Toriyamaia laxiseptata KANMERA \\ P1. 46, Figs. 9, 10
}

1956. Rauserella? sp. KовAYAshi, Trans. Proc. Palaeont. Soc. Japan, N.S. No. 23, p. 227 , pl. 32, figs. 10-12. (Reproduced in 1957, Sci. Rep. Tokyo Kyoiku Daigaku, Sect. C, no. 48, pl. 1, figs. 29,30 ).

1956. Toriyamaia laxiseptata Kanmera, Ibid., No. 24, p. 252-255, p1. 36, figs. 1-14.

1961. Rauserella sp. KaWANo, Bull. Fac. Educ. Yamaguchi Univ., Math. \& Sci., Vo1. 11, p. 


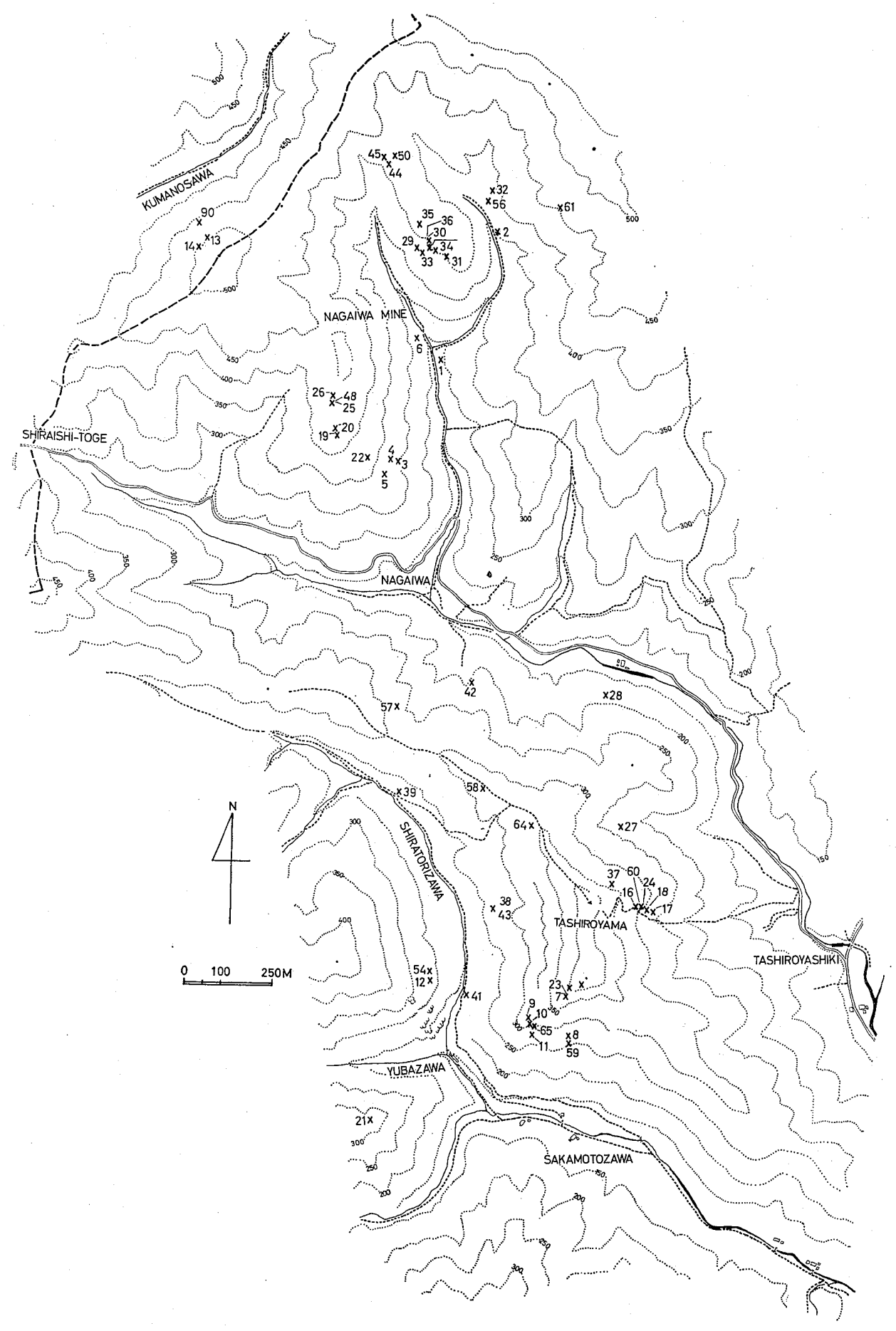

Fig. 3. Topographic map of the Sakamotozawa-Nagaiwa area, showing collecting localities of the Sakamotozawan fusuline fossils indicated in Table 1. 
58, pl. 1, fig. 1.

1962. Toriyamaia laxiseptata, Kanmera, Mem. Fac. Sci., Kyushu Univ., Ser. D, Vol. 14, no. 2, p. 87,88 , pl. 11 , figs. $1-4$; pl. 19 , figs. 8,9 .

1963. Toriyamaia laxiseptata, Sheng, Palaeont. Sinica, N.S. B, No. 10, pl. 157, pl. 4, figs. 36, 37.

Material.-One incomplete axial section (GK. D 12624) from loc. Ks 33 and three oblique sections (GK.D 12604b, 12625, 12712), each from locs. Ks 30, 33 and 39, respectively.

Descriptive remarks.-Shell small, subcylindrical, with broadly rounded polar ends. An incomplete axial section of four and a half volutions is $2.3 \mathrm{~mm}$ long and $0.75 \mathrm{~mm}$ wide. Another specimen has a width of $1.1 \mathrm{~mm}$.

Proloculus minute. First two volutions subspherical. Heights of the first to the fourth (actually $4 \frac{3}{4}$ ) volution $32,56,88$ and 144 microns, respectively.

Spirotheca composed of a tectum and a less dense structureless lower layer. It is thin in the inner volutions and gradually thickens in the outer, measuring $9,12,18$, 24 and 32 microns in thickness in the first to the fifth volution, respectively. Septa not fluted throughout the shell. There are 7 septa to each of outer three volutions. Chomata not recognized.

The obtained material show the same diagnostic features as the types of Toriyamaia laxiseptata from the lowest part of the Kozaki Formation of Kyushu. Minor difference is in that the Kitakami specimens have a longer axis of coiling in the inner two volutions, but this is within a variation of the species.

Occurrence.-Rarely found from Members Sc and Sd. Locs. Ks 30, 33 and 39. Associated species are shown in Table 1.

Family Staffellidae MiKLucho-MaKLay, 1949

Genus Nankinella LEE, 1933

Type-species.-Staffella discoides LEE, 1931

$$
\begin{gathered}
\text { Nankinella kawadai (IGO) } \\
\text { P1. 46, Figs. 6-8 }
\end{gathered}
$$

1956. Hayasakaina? kawadai IGo, Trans. Proc. Palaeont. Soc. Japan, N.S. No. 22, p. 173, 174, p1. 27, figs. 2-5, 7-11, 17-20.

1956. Hayasakaina kotakiensis, IGo, Ibid., p. 172, 173, pl. 27, figs. 1, 6, 12-16.

1958. Nankinella kawadai, Kanmera, Mem. Fac. Sci., Kyushu Univ., Ser. D, Vol. 6, no. 3, p. 210 , pl. 33 , figs. $11-18$.

Type.-This species was erected on more than twenty syntypes (cotypes of IGO), of which the specimen (axial section) illustrated as fig. 7 on plate 27 (IGO, 1956) is here designated as the lectotype of this species.

Material.-One slightly oblique axial section, GK.D 12504 from loc. Ks 6, two tangential sections, GK. D 12618 and 12619 from Ks 18, and seven other oblique sections from $\mathrm{Ks} 18,41$ and 6 . They are almost completely replaced by secondary mineralization.

Descriptive remarks.-Shell small, thick discoidal, with an acute periphery and 
inflated poles. An axial section of probably five volutions is $0.95 \mathrm{~mm}$ long and $1.7 \mathrm{~mm}$ wide, giving a form ratio of 0.56 . Another slightly oblique tangential section (deformed) of probably seven volutions is $2.3 \mathrm{~mm}$ long and $2.8 \mathrm{~mm}$ wide. Heights of probably the fourth and fifth volutions are 246 and 266 microns, respectively. Little can be known about other shell structures owing to complete secondary replacement.

Although the present specimens may be too poorly preserved for the precise identification, the size and shape of the shell and the general appearance of the internal structures agree closely with those of $N$. kawadai.

Occurrence.-Rare in Member $\mathrm{Sb}_{1}$ (locs. Ks 6 and 8) and also in the lower part of Member $\mathrm{Sb}_{2}$ (Ks 18). Some poor specimens from Member Sc (loc. Ks 37) were: referred with a query to this species. Associated species are shown in Table 1.

Family Fusulinidae von MöLleR, 1878

Subfamily Schubertellinae SkINNER, 1931

Genus Minojapanella Fujimoto and Kanuma, 1953

Type-species.-Minojapanella elongata FuJimoto and KANumA, 1953

Minojapanella elongata Fujimoto and KANUmA

Pl. 45, Fig. 10 ; P1. 48, Fig. 16

1953. Minojapanella elongata Fujimoto and Kanuma, Jour. Paleont., Vol. 27, no. 1, p. 152, pl. 19, figs. 1-11.

1961. Minojapanella elongata, Morikawa and Isomi, Geol. Survey of Japan, Rep., No. 191, p. 7, pl. 2, figs. $10-15$.

Lectotype.-Designated by THOMPSON (1954, p. 8) as the specimen (axial section) illustrated by Fujimoto and Kanuma as fig. 1a-c on pl. 19.

Material.-Five slightly diagonal axial sections, GK. D 12622 from loc. Ks 9, 12564 from Ks 21, 12621a from Ks 89, 12605 from Ks 32 and 12623 from Ks 26, and some other oblique sections from locs. Ks 32, 26, 89, 18 and 9. They are more or less deformed and poorly preserved.

Descriptive remarks.-This minute elongate fusiform species has sharply pointed poles and a straight to slightly arcuate axis of coiling. Length and width of a specimen (GK. D 12622) of four volutions $1.29 \mathrm{~mm}$ and $0.27 \mathrm{~mm}$, respectively. Another specimen (GK. D 12605) of probably four volutions $1.7 \mathrm{~mm}$ long. The largest width obtained $0.40 \mathrm{~mm}$ (GK. D 12621b).

Proloculus of a specimen $30-40$ microns in outside diameter. Heights of the first to the fourth volution $16-18,18-24,32-35$ and $48-64$ microns at the middle part of the shell. The first volution is subspherical, and the shell rapidly increases in length in the second to the outer volutions.

Spirotheca, which is largely recrystallized, shows two layers, a dense upper layer and a transparent lower one-probably a tectum and a diaphanotheca, respectively. Thickness of spirotheca in the third volution does not exceed 10 microns.

Septal fluting high and regular throughout the length of the shell, and cuniculi 
well developed in the fourth volution. Chomata distinct in the second to the fourth volutions.

The present species agrees in many respects with Minojapanella elongata FujIMoto. and KANUMA (1953). None of the obtained specimens have five volutions, therefore they have smaller dimensions than the types. If the shells of the same growth-stage are compared, nearly the same heights can be measured.

Occurrence.-Rarely found in Members $\mathrm{Sb}_{1}, \mathrm{Sb}_{2}, \mathrm{Sb}_{3}$ and also in the lower part of Member Sc. Associated species are shown in Table 1.

Subfamily Fusulininae von Möller, 1878

Genus Quasifusulina CHEN, 1934

Type-species.-Fusulina longissima von MöLler, 1878

\section{Quasifusulina tenuissima (SCHELLWIEN)}

P1. 44, Figs. 1-5

1897. Fusulina tenuissima Schellwien, Palaeontogr., Vol. 44, p. 255-257, p1. 19, figs. 7a, 7b, $8,9$.

1913. Fusulina cayeuxi Deprat, Mém. serv. géol. Indochine, Vol. 2, fasc. 1, p. 31-33, pl. 4, figs. 1-10, text-fig. 14.

1914. Fusulina cayeuxi, DePrat, Ibid., Vol. 3, fasc. 1, p. 14, 15, pl. 3, figs. 1-3.

1923. Fusulina cayeuxi, OzAwA, Jap. Jour. Geol. Geogr., Vol. 2, no. 2, p. 35, 36, text-fig. 1.

?1927. Quasifusulina longissima var. phasellus LEE, Palaeont. Sinica, Ser. B, Vol. 4, fasc. 1, p. 116, 117, p1. 21, figs. 1-4.

?1927. Quasifusulina longissima var. tenuis LeE, Ibid., p. 117, 118, pl. 20, fig. 15; pl. 22, figs. 1-5.

?1934. Quasifusulina longissima, CHEN, Ibid., Vol. 4, fasc. 2, p. 92, 93, p1. 5, figs. 6-9.

?1934. Quasifusulina longissima var. compacta, CHEN, Ibid., p. 93, 94, pl. 5, fig. 10.

1940. Quasifusulina cf. cayeuxi, KahLer and KAHLER, Neues Jahrb. für Mineral. Geol. Paläont. Beil.-Bd. 83, Abt. B, p. 354, 355, pl. 10, fig. 2.

1954. Quasifusulina tenuissima, SAURIN, Archives géol. Viet-Nam, No.1, p. 15, 16, pl. 2, figs. 15-17.

1962. Quasifusulina longissima, SUYARI, Jour. Gakugei, Takushima Univ., Nat. Sci., Vol. 12, p. 10 , pl. 4 , figs. 12,13 .

1963. Quasifusulina tenuissima, CHANG, Acta Palaeont. Sinica, Vol. 11, no. 1, p. 45, 46, pl. 1. figs. $1,2$.

1963. Quasifusulina megaprolocula CHANG, Ibid., p. 46, 47 ; p. 59, pl. 1, fig. 6.

Type.-This species was erected on at least four syntypes, including two axial sections. Although both the axial sections are fragmentary, the better oriented section. of them, illustrated as fig. 7a on pl. 19, is designated as the lectotype.

Material.-A number of sectioned specimens have been examined, of which some representative ones are illustrated; GK.D 12562 and 12694 from loc. Ks 14; GK. D 12663. from Ks 9; GK. D 12558 from Ks 18 and 12704 from Ks 17. Many of the obtained. specimens are so strongly deformed that they seemingly show structures as if being not conspecific, as are exemplified as Figs. 2 and 4 on Plate 44.

Description.-Shell subcylindrical, with rounded poles and commonly a slightly arcuate axis of coiling. Of the obtained specimens, the least deformed axial section. 
(GK. D 12562; Pl. 44, Fig. 2) of five volutions attains a length of $9.8 \mathrm{~mm}$ and a width of about $2.1 \mathrm{~mm}$, giving a form ratio of 4.7 . Another fairly well preserved specimen (GK. D 12663 ; Pl. 44, Fig. 3) of five volutions is $9.4 \mathrm{~mm}$ long and about $1.7 \mathrm{~mm}$ thick, and its form ratio is 5.5 .

Proloculus large, subspherical or not uncommonly irregularly subspherical to rectangular; its outside diameter ranges from 340 to 940 microns, being commonly 410 to 570 microns. Thickness of proloculus wall measures 21 to 29 microns.

Shell expands slowly. Heights of volutions of the above mentioned specimen ( $\mathrm{Pl}$. 44, Fig. 2) are 123, 140,172, 180 and 180 microns for the first to the fifth volutions, respectively. Those of another (P1. 44, Fig. 3) are 80, 105, 115, 185 and 205 microns for the corresponding volutions. The specimen illustrated as Fig. 1 on Pl. 1 has much thicker shell, but it must have been compressed towards the direction perpendicular to the figure. Heights of volutions of this specimen are 80, 215, 205, 246, 205 and 287 microns for the first to the sixth volution. Heights of chambers increase gradually polewards.

Spirotheca thin, minutely undulated or rugose; although its structure is obliterated because of recrystallization, that of the inner two volutions appears to be composed of three layers-an extremely thin tectum, a less dense, somewhat transparent central layer partly with very faint alveoli-like structure and the innermost dense coating of a secondary deposit (tectorium). Beyond the second volution the central layer is finely but distinctly alveolar. Thickness of the spirotheca of the first to the sixth volution 16-24, 14-26, 18-28, 20-32, 25-32 and 32-35 microns, respectively.

Septa intensely fluted throughout the shell. The fluting is regular and exhibits a smoothly rounded crest of a fold. Cuniculi well developed in the second to the outer volutions.

Dense secondary deposits fill chambers of the axial regions of the first to the third or the fourth volution, usually forming a sharp boundary on the polar sides, and often coat the inner surfaces of the septa in the middle part of the shell. In most specimens, however, the deposits do not extend to the polar areas of the outermost one or two volutions, although they are not uncommonly spread to the lateral areas. No chomata developed.

Remarks and comparisons.-The specimens from loc. Ks 18 (for the sake of comparison one of them is illustrated as Fig. 4 on $\mathrm{Pl}$. 44) are all strongly deformed and elongated, and they have a thinner spirotheca than the specimens from locs. Ks 14 (Pl. 44, Figs. 1, 2), Ks 17 (P1. 44, Fig. 5) and Ks 9 (Pl. 44, Fig. 3), on which the description given above is primarily based. The thinness of the spirotheca is undoubtedly due to secondary prolongation of the shell by deformation.

Our specimens are closest to the types of Quasifusulina cayeuxi (DEPRAT, 1913, pl. 14, figs. 1-10) and those of Q. tenuissima (SCHELLWIEN, 1897, pl. 19, figs. 7-9). DEPRAT distinguished $Q$. cayeuxi from $Q$. tenuissima in its smaller shell and its slower expansion of the shell, but what he called $Q$. tenuissima (1912, pl. 7, figs. 711 ; 1913, pl. 7, figs. 6-8) are not a species of Quasifusulina, but are referable to Parafusulina or allied genus of the Schwagerininae. MoRIKAWA (1958, p. 118-120) assigned F. cayeuxi DePRAT to Parafusulina and identified the species from the Akasaka Limestone (pl. 22, fig. 1-13). We, however, agree with CHANG (1963, p. 45) in regarding 
DePrat's $F$. cayeuxi as a species of Quasifusulina and as being conspecific with $Q$. tenuissima (SCHELlWIEN).

$Q$. tenuissima closely resembles $Q$. longissima (MöLLER), and the distinction between the two species is a matter of difficulty. In fact LEE (1927) regarded the former species a variety of the latter and at the same time he discriminated other several. varieties of the species. So far as LEE's specimens are concerned, they appear to show simply a variation within a species, and are, in our opinion, closer to Q. tenuissima rather than to $Q$. longissima. The difference between the two species pointed out by previous authors is that $Q$. tenuissima has a comparatively thicker and shorter subcylindrical shell with more numerous volutions than $Q$. longissima, consequently the former having a smaller form ratio (3.0-3.5:1) (LEE, 1927; CHANG, 1963). Comparing the figures of the types of the two species another difference is recognized in that $Q$. tenuissima exhibits more regular septal fluting than $Q$. longissima and has more smoothly rounded crests of the folds. Dense secondary deposits exist in the axial regions of both the species, but they are very variable between individuals and cannot be a distinctive criterion between the two species, although $Q$. tenuissima commonly has broader and denser deposits.

CHANG (1963) referred one of the specimens of $Q$. longissima identified by KANMERA. (1955), from the Yayamadake Limestone, to Q. tenuissima in its shell-shape, but it is a slightly deformed diagonal section, which apparently shows a smaller form ratio. than the actual one. As noted in the explanation of plate 11, it occurred from one and the same rock sample together with a highly elongate specimen shown as fig. 3 . of the same plate, and the two specimens cannot be different species from each other.

The specimen of $Q$. longissima by SUYARI (1962, pl. 4, figs. 12, 13) and $Q$. megaprolocula CHANG (1963, pl. 1, fig. 6) are probably referable to $Q$. tenusssima.

Occurrence.-Abundant at locs. Ks 5, 6, 12, 17 and 18, common in Ks 2 . Also rarely found at $\mathrm{Ks} 4,9,11$ and 61 . This species occurs from Member $\mathrm{Sb}_{1}$ and $\mathrm{Sb}_{2}$ and is restricted to the Lower Subformation.

\section{Subfamily Schwagerininae Dunbar and Henbest, 1930}

Genus Zellia KAHLER and KAHLER, 1937

Type-species.-Pseudoschwagerina (Zellia) heritschi heritschi KAHLER and KAHLER, 1937.

\section{Zellia nunosei HANZAWA}

P1. 45, Figs. 1-5

1939. Pseudoschwagerina (Zellia) nunosei HANZAWA, Jap. Jour. Geol. Geogr., Vol. 16, p. 72, 73, pl. 4, figs. 4-6.

1961. Pseudoschwagerina (Zellia) nunosei, Morikawa and Isomi, Geol. Survey of Japan, Rep., No. 191, p. 9, 10, pl. 3, figs. 1, 2.

1962. Pseudoschwagerina (Zellia) nunosei, Chisaka (partim), Jour. Coll. Art and Sci., Chiba Univ., (Nat. Sci.), Vol. 3, no. 4, p. 536, p1. 1, fig. 11; p1. 2, figs. 2, 4. (Not pl. 1, figs. $7-10$; p1. 2, fig. 3).

1964. Zellia? nunosei, IGo, Jour. Paleont., Vol. 38, no. 2, p. 291, 292, pl. 45, figs. 4, 5; pl. 46, figs. 3-6. 
Types.-One of the syntypes (cotypes of HANZAWA), i. e. the specimen of the axial section (IGPSJ 21356; pl. 4, fig. 4) is designated here as the lectotype of this species. Loc. Magoe, Takata city, Iwate Prefecture. Other syntypes, IGPSJ 21356 (the same register-number as the lectotype; pl. 4, fig. 5) from Magoe; IGPSJ 21357 (pl. 4, fig. 6) from Nagaiwa, Ofunato city.

Material.-GK.D 12501, 12502a and b, 12503a and b, 12504-12510, 12512a and b from locs. Ks 5 and 6 ; fairly strongly deformed.

Remarks and comparisons.--In addition to HANZAWA's original description, IGo's recent study on the topotypes offered the almost complete configuration of this species. The specimens at our hands from Nagaiwa, from where the syntypes came, quite agree with the types of this species in diagnostic features and measurements.

Besides the type area, this species was identified by MorikAWA and Isomi (1961) from the east of the Lake Biwa, central Japan and by CHISAKA (2962) from the Maiya district, the western margin of the Kitakami Massif. Some of CHISAKA's specimens (1962, pl. 1, figs. $7-10)$, however, are probably not referable to this species, because they possess strongly fluted septa.

Occurrence.-Abundant at many horizons of the lower part of Member $\mathrm{Sb}_{1}$; $\mathrm{As}$ sociated species are shown in Table 1.

Genus Pseudoschwagerina Dunbar and Skinner, 1936

Subgenus Robustoschwagerina MikLucho-MAKLAy, 1956

Type-species.-Schwagerina tumida LIKHAREV, 1936

Pseudoschwagerina (Robustoschwagerina) schellwieni HANZAWA

P1. 46, Figs. $2-5$

1938. Pseudoschwagerina schellwieni HanzaWA, Jap. Jour. Geol. Geogr., Vol. 16, Nos. 1-2, p. 71,72 , pl. 4, figs. 1-3.

1941. Pseudoschwagerina schellwieni, Fujлмото, Jour. Geol. Soc. Japan, Vol. 48, no. 569, p. 95 (24), pl. 5 (2), figs. 1-6.

1941. Pseudoschwagerina schellwieni, KAHLer and KAhler, Palaeontogr., Bd. 92, Abt. A, p. 94, pl. 11, figs. 3,4 .

?1936. Schwagerina sp., Hujıмото (Fujimoto), Sci. Rep. Tokyo Bunrika Daigaku, Sect. C, Vol. 1, no. 2, p. 101, 102, pl. 20, figs. 1-3.

1959. Pseudoschwagerina sp., IGo, Sci. Rep. Tokyo Kyoiku Daigaku, Sect. C, Vol. 6, p. 252, p1. 1, fig. 9.

1962. Pseudoschwagerina schellwieni, Chisaka, Jour. Coll. Arts and Sci., Chibn Univ., (Nat. Sci.), Vol. 3, no. 4, p. 535, 536, pl. 1, figs. 3-6; pl. 2, fig. 1.

1963. Pseudoschwagerina schellwieni, CHAO, Acta Palaeont. Sinica, Vol. 11, no. 2, p. 215, pl. 8, fig. 4 ; pl. 9, fig. 11.

1964. Pseudoschwagerina (Robustoschwagerina) schellwieni, IGo, Jour. Paleont., Vol. 38, no. 2, p. 287-290, pl. 46, figs. $1,2$.

Types.-This species was originally described on two syntypes, one of which, the specimen of the axial section illustrated as fig. 1 on plate 4 (IGPSJ 21355), is here designated as the lectotype. The other syntype is also of identical species.

Material.-GK.D 12515-12517 from Ks 35; GK. D 12518, 12692a, 12695a and b from 
Ks 14, and 12519 from Ks 12.

Remarks and comparisons.-This large spherical species of Pseudoschwagerina is, as already described by HANZAWA (1938), IGo (1964) and others, characterized by a moderate proloculus, commonly two or three tightly coiled, thick fusiform juvenarium with massive chomata, succeeding three to four highly inflated volutions, a very thin spirotheca and unfluted septa except in the polar regions of the juvenarium.

The specimens examined well display the characteristics mentioned above and are safely referable to the species. Slight variations are recognized in that the juvenarium may have commonly fewer volutions (one and a half volutions) and less prominent chomata than the types. These variations have, however, already been recognized by IGo (1964) among the topotypes and the specimens from other areas in Japan.

Occurrence.-Rarely found from the upper part of Member $\mathrm{Sb}_{2}$ of the Lower Subformation and commonly from the lower part of Member Sc of the Upper Subformation. Associated species are shown in Table 1.

Genus Paraschwagerina Dunbar and Skinner, 1936

Subgenus Paraschwagerina DUNBAR and SKINNER, 1936

Type-species.-Schwagerina gigantea WHITE, 1932

Paraschwagerina (Paraschwagerina) sp.

P1. 47, Figs. 1-3

Material.-Only six specimens including one axial (slightly diagonal) and five tangential sections have been obtained. GK.D 12520 from loc. Ks $13 ; 12521$ from Ks $90 ; 12690 \mathrm{~b}$ and 12693 from Ks $14 ; 12522$ from Ks $15 ; 12523$ from Ks 7 . A specimen (GK. D 12711) from Ks 2 is referred with a query. All are slightly deformed.

Description.-Shell large, thick fusiform. A specimen attains a length of $19.27 \mathrm{~mm}$ and a width of $6.80 \mathrm{~mm}$ in seven volutions, with a form ratio of 2.83 . Lateral slopes convex in inner volutions and distinctly concave near the poles in outer volutions. Poles bluntly pointed. Axis of coiling appears to be slightly shifted in inner volutions.

Proloculus spherical; its outside diameter measures 205 microns in the specimen mentioned above. Inner two and a half volutions are tightly coiled, and have a straight axis of coiling, sharply pointed poles and straight lateral slopes. The following three volutions are highly expanded, with pointed poles and slightly convex or concave lateral slopes.

The outermost one and a half volutions decrease in chamber-height, but show a considerable increase in length. Heights of the first to the seventh volution of a specimen (Pl. 47, Fig. 1) are 40, 82, 330, 410, 1148, 615 and 697 microns, respectively. The chamber-heights are nearly equal throughout the length of the shell, except in the polar regions.

Spirotheca finely alveolar. Thickness of the spirotheca of the first to the seventh volution of the above mentioned specimen (Pl. 4, Fig. 1) is $32,40,70$ (?), 82, 123-144, 
123 and 112-128 microns, respectively.

Septa thin, nearly plane in the inner two volutions, gently fluted in the third, and strongly fluted in the outer volutions. The folds reach to the tops of the chambers and are generally rounded at their crests. The salient frontal folds of a septum are overlapped by the backward folds of the succeeding septum even in the central part of the shell. Septal counts cannot be known because of the lack of sagittal sections.

Chomata present in the first three volutions. Slight secondary deposits occur in the polar regions of the inner two and a half volutions and in part of the polar areas of the sixth volution as a septal thickening.

Remarks and comparisons.-This species is similar to Paraschwagerina $(P$.) oblonga OzAwA (1925, p. 45, pl. 8, figs. 7, 9). The types of the latter are represented by one axial section, the larger part of which has been destroyed, and the other parallel section, thus being too incomplete for us to fully understand the biocharacters of this species. Despite great efforts by TORIYAMA (1958) on the Akiyoshi fusulinaceans. this species has not been found.

LEE (1927) identified the same species from the Taiyuan Series of North China (pl. 16, figs. 1-3). The Chinese specimens show slight differences from the types in having a smaller proloculus, a more regular septal fluting and a different mode of septal arrangement. In these respects the Kitakami specimens are closer to the Chinese ones rather than the types of the species. In addition, the size and the shape of the shell, the thickness of the spirotheca and the heights of the volutions are also similar to each other. However, better and sufficient material is needed for precise determination. This species is somewhat similar to Acervoschwagerina fujimotoi KANUMA (1959, p. 62 , pl. 4, figs. 6-8) in the shell-shape, but is distinguished by its different mode of septal fluting.

Occurrence.-Rarely found in Member $\mathrm{Sb}_{2}$. Associated species are shown in Table 1.

Subgenus Acervoschwagerina Hanzaw A, 1949

Type-species.-Paraschwagerina (Acervoschwagerina) endoi HANZAWA, 1949

Paraschwagerina (Acervoschwagerina) sp. A

P1. 46, Fig. 1; P1. 47, Figs. 4, 5; P1. 49, Fig. 20

Material.-The obtained specimens are represented by one tangential section (GK.D 12524), one diagonal section (GK. D 12702), one sagittal section (GK.D 12698), one oblique section (GK. D 12707), and two parallel sections passing through the outer margin of the proloculus (GK.D 12697, 12699). All from loc. Ks 16.

Descriptive remarks.-Shell large, fusiform, with bluntly pointed poles and gently convex to straight lateral slopes. Mature specimens of seven volutions attain about $15 \mathrm{~mm}$ in length and 6.5 to $7.5 \mathrm{~mm}$ in width. Form ratio about 2.7 .

Proloculus small; its outside diameter measures 96 and 140 microns in two specimens. Inner three volutions are tightly coiled and have distinct chomata and 
rather sharply pointed poles. At nearly the end of the third volution the shell begins to expand rapidly. The fourth and fifth volutions assume the heighest chambers and from there to maturity the chambers gradually decrease in height. In a sagittal section (GK. D 12698) the heights of the volutions in the first to the seventh measure $60,82,287,902,1230,615$ and 290 microns, respectively. Those of the first to the sixth in other three specimens are 48-82, 80-123, 176-328, 966-1020, 820-1435 and 615-656 microns, respectively.

Spirotheca rather coarsely alveolar. Thickness of spirotheca of the first to the seventh volution is $24-32,26-37,42-56,56-80,96-128,136-168$ and $112-136$ microns, respectively.

Septa thin, especially in the fourth and fifth volutions. They are rather strongly and very irregularly fluted almost throughout the growth except in the inner two volutions where it is weakly fluted in the polar regions. Septal counts of the first: to the sixth volution of three specimens are $12-14,18,21-22,25-27,31-37$ and $40-49$, respectively. Small chomata develop in only inner two volutions.

This species shows diagnostic features of Acervoschwagerina in the irregular and complicate septal fluting, the mode of expansion of the shell and the general shellshape. It is clearly distinguished, however, from $A$. endoi HANZAwA in its less. irregular and complicated septal fluting.

Occurrence.-Common at loc. Ks 16 in the Member $\mathrm{Sb}_{3}$.

\section{Paraschwagerina (Acervoschwagerina) sp. B.}

P1. 51, Figs. 10-12

Material.-Two incomplete tangential section (GK. D 12703) and one sagittal section: (GK. D 12707) from loc. Ks 17, and some other oblique sections from Ks 17 and 3.

Descriptive remarks.-Shell inflated fusiform, with convex lateral slopes. Poles. may be rounded. Shell-size of complete mature specimens is not known, but a specimen of six volutions is about $7.5 \mathrm{~mm}$ long and $5 \mathrm{~mm}$ thick.

Proloculus small; its outside diameter measures 164 microns in a specimen. Inner two or three and a half volutions are tightly coiled, moderately fusiform with sharply pointed poles. Succeeding three or three and a half volutions are highly expanded and have rounded poles. Heights of volutions of the second to the sixth of a specimen: (GK. D 12703; Pl. 51, Fig. 10) are 60, 112, 287, 984 and 820 microns, respectively. Those of the first to the fifth volution of a sagittal section (GK. D 12707; Pl. 51, Fig. 12) are $60,123,287,533$ and 738 microns respectively.

Spirotheca rather finely alveolar. Thickness of spirotheca of the second to the sixth volution of a specimen (GK. D 12703) is $16,32,48,66$ and 100 microns, respectively.

Septa irregularly fluted to the tops of the chambers almost throughout the shell except in the central part of the juvenile three volutions. Septal counts of the first to fifth volution of a specimen (GK. D 12707) are 9, 16, 17, 20(?) and 24, respectively.

Small symmetrical chomata are developed in the Triticites-like juvenile three volutions.

Although the obtained specimens are all incomplete, the mode of their septal fluting and the expansion of the shell show that they are to be referable to Acervo- 
schwagerina, but are probably distinguished from the known species of the genus. This species differs from $A$. endoi HANZAw A in the less irregularly fluted septa and the more gradual expansion of the shell and the thicker spirotheca in outer volutions. It is also different from $A$. sp. A described in the preceding pages in its more gradual expansion of the shell.

Occurrence.-Rarely found at locs. Ks 3 and 17 in Member $\mathrm{Sb}_{2}$.

Genus Monodiexodina Sosnina, 1956

Type-species.-Schwagerina wanneri sutschania DouTKEVITCH, 1953

Subgenus Ferganites M.-MACLAY, 1959

Type-species.-Triticites ferganensis M.-MACLAY, 1950

Monodiexodina (Ferganites) langsonensis (SAURIN)

P1. 48, Figs. 1-11

1950. Triticites langsonensis SAURIN, Bull. sèrv., géol. Indochine, Vol. 29, fasc. 5, p. 23-25, pl. 4, figs. 1-11, 13-15.

Type.-The lectotype is here designated as the specimen illustrated as fig. 7 on plate 4 by SAURIN (1950).

Material.-Axial section-GK. D 12658a, 12640, 12659, 12644 from loc. Ks $9 ; 12666$ and 12667 from loc. Ks $61 ; 12641$ from Ks 24; GK. D 12642b from loc. Ks 24. Tangential sections-12656 and 12661a and b from loc. Ks $9 ; 12665$ from Ks 61 . There are a number of axial and tangential sections from loc. Ks 11, 59 and 60, but they are secondarily more or less deformed.

Description.-Shell elongate subcylindrical, with a straight to slightly curved axis of coiling. Poles usually rounded but rarely bluntly pointed. The middle three-fourths of the shell are generally almost equal in thickness, but in some specimens the shell is slightly inflated in the central part.

Mature shells consist of six to seven volutions and attain 7.0 to $8.8 \mathrm{~mm}$ in length and 1.3 to $1.8 \mathrm{~mm}$ in width. The largest specimen (GK. D $12640 ;$ P1.48, Fig. 2) of eight volutions is $10.3 \mathrm{~mm}$ long and $2.0 \mathrm{~mm}$ wide. Form ratios of well preserved typical specimens are 4.2 to $5.1: 1$, but not a small number of specimens have been prolonged along the axis of coiling and their form ratios attain as large as 5.7.

Proloculus small; its outside diameter ranges from 102 to 164 microns, averaging 133 microns in eleven specimens. First one and a half volutions are ellipsoidal, the succeeding two or two and a half volutions become subcylindrical, and generally beyond the fourth volution the shell is greatly extended, assuming its mature cylindrical shape. Heights of volutions in the first to the seventh of four less deformed typical specimens are 48-50, 56-64, 68-69, 96-120, 128-168, 168-234 and 194-196 microns, respectively. Thus the shell expands slowly. Form ratios of the first to the sixth volution of the above mentioned specimens are $2.0-2.6,2.1-2.7,2.3-3.1,2.8-4.0,3.5-4.5$ and 4.3-4.4, respectively.

Spirotheca rather coarsely alveolar. It attains a thickness of 13-15, 18-24. 24-32, 
$32-48,48-64,64-80$ and 90 microns, respectively in the first to the seventh volution. It maintains nearly the same thickness throughout the length of the shell except for the extreme polar ends, and its surfaces are smooth laterally.

Septa regularly fluted throughout the shell. The fluting is generally confined to the lower part of the septa and the crests of the folds are smoothly rounded. No cuniculi are recognized. Septal counts of the first to the fifth volution in a specimen (GK. D 12642b; Pl. 48, Fig. 9) are 10, 13, 15, 18 and 22, respectively.

Tunnel clearly defined and rather wide, usually with a straight path. Tunnel angles attain 25-35 degrees in the first two volutions, increase to 50-60 degrees in the outer volutions. Chomata occur in all volutions except the last volution. They are generally small and symmetrical but near the septa are steep-sided or overhanging to the tunnel. Dense axial fillings occur in the polar regions of the second to the fifth or the sixth volution, but the deposits are commonly confined to a narrow zone.

Remarks.-Besides the above mentioned material on which the description of this species is based there are a number of axial and sagittal sections from locs. Ks 11 , $9,59,60$ and 24. For the sake of comparison some of them are illustrated as Fig. 6 (GK. D 12647 from loc. Ks 11) and Fig. 7 (GK.D 12644 from loc. Ks 9) on Plate 48. As is shown in these figures, they have a thinner shell, smaller heights of volutions and a thinner spirotheca for the corresponding volutions. They are, however, almost identical with the thicker examples in the general shell-shape, the proloculus-size, the nature of septal fluting and the axial fillings. There are also not a few specimens which are intermediate in dimensions. These thinner specimens are undoubtedly the the deformed ones prolonged along the axis of coiling by secondary deformation.

Comparison.-Our specimens are identical with the types of this species from the Ky-Lua Limestone of Langson, Viet-Nam, in many diagnostic features, but they are generally slightly slenderer. This is probably due to the secondary deformation as mentioned above. This species is similar to Monodiexodina pailensis (ScHWAGER, 1877) and M. kattaensis (SCHWAGER, 1877), both from the Lower Productus Limestone of the Salt Range. Compared with ScHwaGER's syntypes and DuNBAR's hypotypes (1933) of $M$. kattaensis, the present species has more numerous volutions for the nearly equal or smaller size of the shell, smaller heights of volutions and a distinctly weaker septal fluting.

The present species agrees closely with $M$. pailensis in the size and shape of the shell, the proloculus size, the thickness of the spirotheca, the septal counts and the mode of septal fluting. It has, however, a lower and weaker septal fluting than that of $M$. pailensis. In the former the septa in the middle part of the shell are only feebly fluted in their lower part, whereas in the latter they are fairly strongly fluted even near the tunnel.

This species is also similar to $M$. gracilis (MEEK, 1864) from California and $M$. alaskensis (DunBAR, 1946) from Kuiu Island, Alaska, but it differs from the former in its more subcylindrical inner volutions and smaller heights in the outer volutions, and from the latter in its more numerous volutions for the nearly equal size of the shell.

Occurrence.-Abundant in the lower part of Member $\mathrm{Sb}_{2}$. Associated species are shown in Table 1. 
Genus Nipponitella HanZAWA, 1938

Type-species.-Nipponitella explicata HANZAWA, 1938

\title{
Nipponitella explicata HANZAWA
}

\author{
P1. 49, Figs. 1-19
}

1938. Nipponitella explicata Hanzawa, Proc. Imp. Acad, Japan, Vol. 14, no. 7, p. 256, 257, figs. 8-16.

Lectotype.-This species was established on at least nine syntypes (cotypes of HANZAWA), of which the specimen of fig. 11 (HANZAWA, 1938, p. 258) was selected as the lectotype by THOMPSON (1964, p. C 418, noted as holotype).

Material.-Axial section-GK. D 12652a and b, 12653a, 12654 from loc. Ks 11, 12719, 12722a, 12723a, 12724, 12728a, b and c from Ks 22 and GK. D 12654 from Ks 59. Sagittal section-GK. D 12687a and b, 12721, 12722b, 12723b and c, 12725, 12726a and b, 12727a and $b, 12728 d$, e and $f$ from $K s 22$. Besides these, there are a number of tangential section from loc. Ks 11, 22, 23, 24, 26, 59 and 60. Some of them are illustrated.

Descriptive remarks. - The diagnostic features of this aberrant species was already concisely described by HANZAWA (1938, p. 256). Our specimens from the type area of this species and the adjacent area to the north are safely identified with the species by the bimorphic development of the shell in ontogeny with early subcylindrical whorls and the ultimate uncoiled gerontic whorl. The outside diameter of the spherical proloculus ranges from 115 to 170 microns, usually from 128 to 145 microns. Proloculus wall is rather thick and attains 20 to 30 microns. The subcylindrical part of the shell consists mostly of four to five volutions with a straight axis of coiling and narrowly rounded to bluntly pointed poles, and attains 3.0 to $4.6 \mathrm{~mm}$ in length and 1.1 to $1.6 \mathrm{~mm}$ in width. The shell of the subcylindrical part shows a large extent of variation with form ratios ranging $2.2: 1$ to $3.5: 1$. This is probably due to the secondary deformation. Indeed, the shells, the axis of which has been laid parallel to the bedding plane, have a form ratio as large as 3.0 to $3.5: 1$, whereas those which have been embedded obliquely to the bedding plane are relatively thicker, giving smaller form ratios of 2.2 to 2.9 .

Similarly, the heights of volutions and the thickness of spirotheca are also considerably variable in relation to the attitude of the shell in beds. The heights of volutions of the first to the fifth of less deformed ten specimens are 48-64, 80-96, 96-112, 148-218 and 258-353 microns, respectively. The thickness of the spirotheca of the first to the fifth volution of the same specimens is $15-20,20-27,30-32,45-64$ and $48-64$ microns, respectively.

The gerontic uncoiled part is taken place at the fourth and a half to the fifth and a half volutions and attains usually 5 to $6 \mathrm{~mm}$, at most $7 \mathrm{~mm}$ in length and usually 4 to $4.5 \mathrm{~mm}$, at most $5 \mathrm{~mm}$ in width (excluding the width of the planispiral part). The height of the uncoiled volution (measured normal to the whorl from the bottom of the chamber to the upper surface of the spirotheca) is 400 to 700 microns.

The septal counts of the first to the fifth volution of the planispiral part of 
seven specimens are $9-10,13-15,15-18,17-21$ and $20-26$, respectively and that of the uncoiled part is $24-26$. The spirothecal structure and the septal fluting were already described adequately by HaNZAWA (1938).

This species occurs exclusively crowded in some beds, but is associated with Monodiexodina langsonensis in some others. The mature shells of the two species are apparently very distinct from each other, but their inner volutions exhibit somewhat similar features in many respects.

Occurrence.-Abundant in the upper part of Member $\mathrm{Sb}_{1}$ and many horizons of Member $\mathrm{Sb}_{2}$.

Genus Rugosofusulina RAuser-CHERnoussova, 1937

Type-species.-Alveolina prisca EHRENBERG, 1854 [=Fusulina prisca (EHRENBERG) MÖLLER, 1878]

\section{Rugosofusulina alpina (SCHELLWIEN) \\ Pl. 50, Figs. 1-5}

1898. Fusulina aplina Schellwien, Palaeontogr., Vol. 44, p. 243.

1898. Fusulina aplina var. antiqua Schellwien, Ibid., p. 244, 245, pl. 17, figs. 1-4.

1898. Fusulina alpina var. fragilis Schellwien, Ibid., p. 245, pl. 17, figs. 8, 9.

1898. Fusulina alpina var. communis Schellwien, Ibid., p. 246, 247, pl. 17, figs. 5-7.

1927. Schwagerina alpina, LeE, Palaeont. Sinica, Ser. B, Vol. 4, fasc. 1, p. 94-96, pl. 15, figs. $1-11$.

1934. Schellwienia alpina, Chen, Ibid., Vol. 4, fasc. 2, p. 62, pl. 5, figs. 3-5.

1937. Rugosofusulina alpina, Rauser-Chernoussova, Lab. Palaeont. Moscow Univ., Studies in Micropaleont., Vol. 1, fasc. 1, pl. 2, fig. 7.

[Not Fusulina alpina var. antiqua DEPRAT, 1912; Pseudofusulina alpina var. communis Huzıмото, 1936; Rugosofusulina alpina IGo, 1957; "Schwagerina". aff. alpina NogAmI, 1962]

Type.-SCHELLWIEN (1898, p. 243-247) established this species without designating the holotype. He distinguished in this species three varieties, var. antiqua (pl. 17, figs. 1-4), var. fragilis (p1. 17, figs. 8, 9) and var. communis (pl. 17, figs. 5-7). Later he (1904) also added to the species var. vetista (pl. 15, fig. 1-4) and var. rossica (pl. 15, figs. 5-13; pl. 16, figs. 1, 2).

The former three are considered to be simply variation within one and the same species, i.e. R. alpina. The specimen of fig. 2 on plate 17 by ScHELLwIEN (1898) is here designated as the lectotype of this species.

Material-Axial section-GK. D 12563a and b, 12564a and 12565 from loc. Ks 21; GK. D 12661c and 12662 from Ks 9; GK. D 12570 from Ks 20. Tangential sectionGK.D 12566 from loc. 380418.2. There some other tangential and diagonal sections from loc. Ks 54, and a few specimens from loc. Ks 7 which are referred with a query.

Descriptive remarks. - The obtained specimens are secondarily compressed normal to the axis of the shell, consequently being more or less elongated along the axis. Shells of this elongate, subcylindrical species attain 14 to $16 \mathrm{~mm}$ in length and 2.2 to $3.5 \mathrm{~mm}$ in width in four to six volutions.

Proloculus spherical; its outside diameter ranges from 145 to 225 microns. Shells 
rapidly increase in length, especially in the second to the fourth volution. Inner three volutions have sharply pointed poles. Heights of volutions of the first to the fifth of five specimens, although they are of approximate values due to secondary deformation, are 82-123, 143-164, 246-320, 328-451 and 287-418 microns, respectively.

Spirotheca coarsely alveolar and irregularly rugose. Thickness of the spirotheca of the first to the fifth volution is $32-43,46-68,68-82,82-123$ and $120-128$ microns, respectively.

Septa very thin. Septal fluting is low and rather regular in the area adjacent to the tunnel but becomes high and very irregular in the lateral sides.

Rudimentary chomata occur only in the first volution.

Comparisons.-We agree with LEE's opinion (1927, p. 96) that, among the five varieties discriminated by SCHELLWIEN $(1898,1908)$, var. antiqua, var. fragilis and var. communis represent simply variation within one and the same species, i. e., alpina. However both var. vetista and var. rossica are probably separated as different species.

$R$. alpina thus defined is characterized by the elongate subcylindrical shell with four to five volutions, the rapid expansion of the shell and the irregularly fluted septa.

The present specimens are secondarily more or less demolished, especially the shape of the shell is strongly elongated. The specimens (P1. 50, Figs. 1 and 2) from loc. Ks 21 agree with $R$. alpina, especially with var. antiqua from the Carnic Alps, in many important characters. Those (P1. 50, Figs. 4 and 5) from loc. Ks 9 exhibit the shell-structures almost comparable to var. fragilis.

R. alpina identified by IGo (1957, pl. 14, figs. 11-15; pl. 15, figs. 1, 2) may probably be a different species because it has a comparatively thicker and shorter shell with obtuse poles, a more strongly and minutely dimpled spirotheca and a larger proloculus.

The present species is also similar to "Schwagerina" laxissima DUNBAR and SkINNER (1937, pl. 68, figs. 1-11) which is a species belonging to the group of alpina, but has more rapidly expanded and elongated inner volutions.

Occurrence.-Abundant at locs. Ks 20 and 21, rarely found at Ks 9. All from Member $\mathrm{Sb}_{1}$.

\section{Rugosofusulina rossica (ScHELLwIEN)}

\section{P1. 50, Figs. 6, 7 ?}

1908. Fusulina alpina var. rossica Schellwien, Palaeontogr., Vol. 55, p. 171, 172, pl. 15, figs. 5-13.

Type.-SchellwiEn's $F$. alpina var. rossica originally included specimens from two areas, i.e. the Donetz basin and Gshel. One (pl. 15, fig. 5) of those from the Donetz basin is very similar to the typical form of $R$. alpina including SchelLwIEN's three varieties, var. antiqua, var. fragilis and var. communis (SCHELlwIEN, 1898, pl. 17, figs. 1-9), and is probably regarded as the typical subspecies of $R$. alpina. However another specimen (pl. 15, fig. 6) from the Donetz basin and the specimens (pl. 15, fig. 13; pl. 16, figs. 1, 2) from the Cora beds of Gshel show a clear distinction from the typical form of $R$. alpina, as already mentioned by IGO (1957, p. 240). They possess thick fusiform inner volutions and secondary deposits which fill chambers and thicken 
the septa in the inner two or three volutions. These features in the juvenile stage serve to differentiate them from $R$. alpina. Anyone who is accessible to the types. should reexamine and desinate the lectotype.

Material.--One axial section (GK.D 12668) from loc. Ks 61. Another axial section (GK. D 12569) from loc. Ks 20 is referred with a query. The following description is. mostly based on the former.

Descriptive remarks.-Shell elongate subcylindrical, with a slightly curved axis. of coiling and bluntly rounded poles. A specimen of four volutions is $11.3 \mathrm{~mm}$ long and $2.3 \mathrm{~mm}$ wide, giving a form ratio of 4.8 .

Proloculus rather large, attaining 369 microns in its outside diameter. Shell expands rather rapidly. Heights of the first to the fourth volution of the specimen mentioned above 129, 184, 290 and 290 microns, respectively. Chambers gradually increase in height polewards.

Spirotheca finely alveolar, and irregularly rugose. Its thickness measures 50, 70, 85 and 102 microns in the first to the fourth volution, respectively. Septa strongly fluted throughout the shell and the fluting is rather regular in the inner volutions but very irregular in the outer ones.

Dense secondary deposits fill the chambers of the axial regions and thicken the septa in the inner two and a half volutions.

The present specimens are closely allied in diagnostic features to $R$. rossica from the Cora beds of Gshel, but they have a slightly larger shell and a thicker spirotheca for the corresponding volutions. For the precise identification more numerous specimens. are needed.

Occurrence.-Rare in Member $\mathrm{Sb}_{2}$.

Rugosofusulina sp. aff. R. serrata RAUSER-CHERNOUSSOVA

P1. 52, Figs. 8-11

Compare.-

1937. Rugosofusulina serrata Rauser-Chernoussova, Lab: Palaeont. Moscow Univ., Studies: in Micropal., Vol. 1, fasc. 1, p. 22, pl. 1, figs. 4-6.

1958. Rugosofusulina serrata, Kanmera, Mem. Fac. Sci., Kyshu Univ., Ser. D, Vol. 6, no. 3, p. 186-189, pl. 30, figs. 11-19.

Material.-GK.D 12591 and 12636 from loc. Ks 36; GK.D 12637 and 12638 from Ks 32, and GK. D 12639 from Ks 34, all axial section. They are poorly preserved.

Descriptive remarks.-Shell fusiform with bluntly pointed poles and convex lateral slopes. Shell of six volutions 7.0 to $7.2 \mathrm{~mm}$ long and 2.5 to $2.9 \mathrm{~mm}$ wide, and a specimens of seven volutions attains $8 \mathrm{~mm}$ in length and $3.2 \mathrm{~mm}$ in width. Form ratios 2.4 to 2.53 .

Proloculus 200 to 250 microns in its outside diameter. First volution ellipsoidal; Beyond the second volution the shells maintain a fusiform shape throughout the growth. Heights of the first to the sixth volutions are 75-92, 123-143, 205-226, 246-297, 287-308 and 287-328 microns, respectively. Chambers gradually increase in height polewards.

Spirotheca finely alveolar. It is irregularly rugose in part, and the lower margin 
of the keriotheca is also undulating in part independently with the rugosity or unevenness of the tectum. Thickness of spirotheca of the first six volutions is 24-32, 40-43, 48-64, 72-80, 80-96 and 112 microns, respectively.

Septa strongly fluted throughout the length of the shell. Crests of the septal fluting are mostly rounded. Because of the lack of sagittal sections septal counts cannot be given. Fairly dense deposits fill the chambers of the axial regions of the second to fourth or fifth volutions.

Comparisons.-This species is closely allied to species of Rugosofusulina such as $R$. serrata RAUSER-CHERNOUSSOVA (1937) and its subspecies $R$. serrata valens RAUSERCHeRnoussova (1937) and $R$. serrata transita RAUSER-CHERNoussova (1937) in many respects. It is, however, distinguished from them in having wider and denser axial fillings. In having axial fillings it approaches $R$. ruzenzevi RAUSER-CHERNOUSSOVA (1937), but the latter has chambers which increase more distinctly in height polewards and a more complicate septal fluting.

Occurrence.-Common in Member Sc. Associated species are shown in Table 1.

Rugosofusulina sp.

Pl. 44. Fig. 6

Material.-One axial section (GK.D 12606) from loc. Ks 2; two diagonal section (GK. D 12607a and b) and one sagittal section (GK. D 12608) from Ks 5 ; one tangential section (GK.D 12609) from Ks 11 . The above mentioned axial section is fairly well preserved, but others are strongly deformed. The measurements given in the following description is entirely based on the axial section.

Descriptive remarks.-Shell fusiform with a subcylindrical middle part and nearly straight to slightly convex lateral slopes tapering towards acute poles. A specimen of five volutions is $10 \mathrm{~mm}$ long and $3.6 \mathrm{~mm}$ wide, giving a form ratio of 2.77 .

Proloculus measures 410 microns. Shell expands uniformly except in the ultimate volution. Heights of volutions of the first to the fifth 205, 246,287, 369 and 410 microns respectively. Radius vectors of the same volutions $389,615,902,1271$ and 1681 microns, respectively. Chambers gradually increase in height polewards.

Spirotheca thin, finely alveolar. Thickness of spirotheca of the first to the fifth volution measures $64,72,90,96$ and 80 microns, respectively. Thus it thickens very gradually. It is irregularly and finely dimpled throughout the growth of the shell.

Septa strongly fluted throughout the shell. The fluting is rather regular in the central two-thirds of the shell, but very irregular in the polar areas.

Dense deposits fill the axial regions of the second and third volutions and coat the surfaces of the septa in the areas adjacent to the tunnel in the outer volutions.

DEPRAT (1915) illustrated four specimens of "Fusulina" japonica from Indochina, of which two specimens of figs. 18 and 20 on his plate 1 are not identical with other two (figs. 17 and 19 on the same plate) and cannot be referable to Schwagerina japonica but are a species of Rugosofusulina. Our specimens resemble those specimens in the general features, but exact comparison cannot be made because of the insufficiency of the material. 
Occurrence.-Abundant at loc. Ks 5, rare at Ks 2 and Ks 11. All from Members $\mathrm{Sb}_{1}$ and $\mathrm{Sb}_{2}$.

Genus Pseudofusulina Dunbar and Skinner, 1931

Type-species.-Pseudofusulna huecoensis DUnBar and SkInNER, 1931

\section{Pseudofusulina vulgaris (SCHeLlwIEN and DyRENFUrTh)}

Type.-Of the original syntypes the specimen illustrated as fig. $1^{*}$ (axial section) on plate 4 was designated by TORIYAma (1958, p. 167) as the lectotype.

Diagnosis.-Shell of six to seven volutions highly vaulted short fusiform to subspherical, with bluntly pointed poles. Proloculus moderate in size. Shell expands rapidly. Spirotheca thick, coarsely alveolar. Septal fluting almost reaches tops of chambers throughout the shell. Phrenothecae commonly occur.

Remarks.-This species originally included, besides the typical form (pl. 14, figs. 1 , 2), three varieties, i. e. var. globosa (pl. 13, figs. 7, 8; pl. 14, figs. 3-7), var. fusiformis (pl. 15, figs. 1-4) and var. exigua (pl. 15, figs. 5-8). In addition, Fusulina watanabei OzAw A (1923, p. 38, pl. 5, fig. la, b) was regarded by LeE (1927) as a variety of this species, and Pseudofusulina vulgaris var. megaspherica TORIYAMA (1958, p. 170-172, pl. 22, figs. $8-17$; pl. 23, figs. 1-3) is another form of this species.

Of these forms, $F$. vulgaris var. fusiformis has been separated by many authors as a distinct species (the lectotype, fig. 2 on pl. 15, designated by THOMPson, 1948, p. $52,53)$ by its elongate subcylindrical shell. $F$. vulgaris var. exigua is also better separated as a distinct species, because it has a moderately thick fusiform shape and a smaller and more tightly coiled shell than that of the typical form. For the time being the three forms are separated subspecifically as follows:

$P$. vulgaris vulgaris: characterized by a short, thick fusiform shell, almost straight

to slightly concave lateral slopes and a uniform expansion of the shell

P. vulgaris globosa: characterized by a relatively globular shell, highly convex lateral

slopes which commonly become concave near the poles, a relatively rapid expansion

of the shell and an irregular septal fluting

$P$. vulgaris watanabei: characterized by axial fillings.

$P$. vulgaris var. megaspherica was originally named for the examples which have a larger shell, a larger proloculus and a thicker spirotheca. However we agree with NoGAMI (1961, p. 213) in regarding it as simply a variation within $P$. vulgaris globosa.

\section{Pseudofusulina vulgaris vulgaris (SCHELlwien and DyRENFurTH) \\ P1. 51, Figs. 1-3}

1909. Fusulina vulgaris Schellwien and Dyrenfurth, Palaeontogr., Bd. 56, p. 163, 164, pl. 14, figs. 1,2 .

1925. Schellwienia vulgaris, Ozawa, Jour. Coll. Sci., Imp. Univ. Tokyo, Vol. 45, art. 6, p. 23, 24, pl. 7 , fig. 3.

1927. Schellwienia vulgaris, LeE, Palaeont. Sinica, Ser. B. Vol. 4, fasc. 1, p. 59-64, pl. 8,

\footnotetext{
*. Erroneously noted as fig. 2 .
} 
figs. $6-9,11,12 ;$ pl. 9, fig. 9.

1934. Pseudofusulina vulgaris, CHEN, Ibid., fasc. 2, p. 67, 68, p1. 6, fig. 10.

1936. Pseudofusulina vulgaris, Huziмото (Fuјмото), Sci. Rept. Tokyo Bunrika Daigaku, Sect. C, Vol. 1, no. 2, p. 75-77, pl. 11, figs. 1-7.

1949. Pseudofusulina vulgaris, Miklucho-Maklay, Leningrad. Gosud. Univ., p. 87, 88, pl. 8, figs. 2, 3 .

1950. Pseudofusulina vulgaris, SAURIN, Bull. serv. géol. Indochine, Vol.29, fasc. 5, p. 27, 28, pl. 6, figs. 1, 2, 9.

1955. Pseudofusulina vulgaris, Morikawa, Sci. Rep. Saitama Univ., Ser. B, Vol. 2, no. 1, p. 89, 90, pl. 9, figs. 1-6.

1955. Pseudofusulina vulgaris var. horiguchii MorikawA, Ibid., p. 90, 91, pl. 9, figs. 7-14.

1958. Pseudofusulina vulgaris, Toriyama, Mem. Fac. Sci. Kyushu Univ., Ser. D, Vol. 7, p. 164-168, pl. 20, figs. 12-18; pl. 21, figs. 1-15.

?1959. Pseudofusulina vulgaris, Kanuma, Bull. Tokyo Gakugei Univ., Vol. 10, pl. 74, 75, pl.8, figs. 13, 14.

?1959. Pseudofusulina vulgaris var. pseudowatanabei Kanuma (partim), Ibid., p. 77, p1. 8, fig. 10 .

1959. Pseudofusulina vulgaris, IGo, Sci. Rep. Tokyo Kyoiku Daigaku, Sect. C, vol. 6“ p. 239, 240, pl. 1 , fig. 7 .

1961. Pseudofusulina vulgaris, Nogami, Mem. Coll. Sci., Univ. Kyoto, Ser. B, Vol. 27, no. 3, p. 210,211 , pl. 9, figs. 1-3.

1961. Pseudofusulina vulgaris, Kawano, Bull. Fac. Educ. Yamaguchi Univ., Math. \& Sci., Vol. 11 (spec. vol.), p. 92-94, pl. 6, figs. 4-19.

1961. Pseudofusulina vulgaris, Morikawa and Isomi, Geol. Survey of Japan, Rep., No. 191, p. 16, 17, pl. 13, figs. 1-4.

1963. Pseudofusulina vulgaris, Sheng, Palaeont. Sinica, N.S. No. 10, p. 192, p1. 16, figs. $6-7$.

Type.-Of the two syntypes from Darwas the specimen of fig. 1 (axial section) on pl. 14 was designated by ToRiYAMA (1958, p. 167) as the lectotype.

Material.-Fourteen well oriented axial sections and several sagittal sections from locs. Ks 43, 40, 52 and 53. GK. D 12528, 12529, $12530 \mathrm{a}$ and $\mathrm{b} ; 12531 \mathrm{a}$ and $\mathrm{b}$; 1253212536, 12537a and b; 12539a and b; 12540, 12546. They are somewhat recrystallized. but not deformed.

Descriptive remarks.-The diagnostic features of this well-known and widespread species in the Carnic Alps, Darwas and Russian Platform regions and Eastern Asia are the highly inflated, short fusiform shell with bluntly pointed poles and straight to slightly concave lateral slopes, the regular expansion of the shell, the thick spirotheca, and the strongly and regularly fluted septa.

In these characteristics our specimens agree very closely with the lectotype of this subspecies and with specimens identified by OzAWA, MORIKAWA and Isomi, IGO, and NogAmi. They are, however, generally larger than the type and most of other previously described specimens from various areas, attaining commonly a length of 7.8 to $9.5 \mathrm{~mm}$ and a width of 4.5 to $6.0 \mathrm{~mm}$ in six and a half to seven and a half volutons. Their form ratio ranges from 1.44 to 1.85. Proloculus is large, and its outside diameter is 400 to 500 microns, averaging 450 microns for six well oriented sections. An extraordinary large proloculus attains 600 microns. These dimensions are close to those of the specimens from the east of the Lake Biwa (MoRIKAWA and IsOMI, 1961).

Like the previously described ones, our specimens show a fairly large extent of 
variation in the size and the shape of the shell and the rate of expansion. For thesake of comparison three specimens are illustrated (Pl. 8, Figs. 1-3).

Occurrence.-Abundant at locs. Ks 40, 43, 52 and 53 in the lower part of Member Sc. No other fusulinaceans are associated.

\section{Pseudofusulina vulgaris globosa (SchellWIEN and DyRENFURTH) P1. 51, Figs. 4-9}

1909. Fusulina vulgaris var. globosa Sehellwien and Dyrenfurth, Palaeontogr., Vol. 56, p. 164, 165, pl. 13, figs. 7, 8; pl. 14, figs. 3-7.

1925. Schellwienia vulgaris var. globosa, OzAwA, Jour. Coll. Sci., Imp. Univ. Tokyo, Vol. 45, art. 6 , p. 24,25 , p1. 7 , figs. 1,2 .

1927. Schellwienia vulgaris var. globosa, LeE, Palaeont. Sinica, Ser. B, Vol. 4, fasc. 1, p. 67, p1. 9, fig. 12.

1936. Pseudofusulina vulgaris var. globosa, Huzıмoto (Fujimoto), Sci. Rep. Tokyo Kyoiku Daigaku, Sect. C, Vol. 1, p. 77, 78, pl. 12, figs. 1-7; pl. 14, figs. 1, 2.

1958. Pseudofusulina vulgaris var. globosa, ToriYAma, Mem. Fac. Sci., Kyushu Univ., Ser. D, Vol. 7, p. 168-170, pl. 21, figs. 16-18; p1. 22, figs. 1-7.

1958. Pseudofusulina vulgaris var. megaspherica TORIYAMA, Ibid., p. 170-172, pl. 22, figs. 8-17; pl. 23, figs. $1-3$.

1958. Pseudofusulina globosa (Deprat) var. exilis Toriyama, Ibid., p. 175-178, pl. 23, figs. $7-16$; pl. 24, figs. $1-20$.

1958. Schwagerina vulgaris, SAKAgAmI, Jour. Hokkaido Gakugei Univ., Vol. 9, no. 2, p. 83, 84, p1. 2, figs. 10, 11,17 .

1958. Pseudofusulina vulgaris var. globosa, SAKAGAMI, Ibid., p. 85, p1. 2, fig. 12.

1959. Pseudofusulina vulgaris var. globosa, IGo, Sci. Rep. Tokyo Kyoiku Daigaku, Sect. C, Vol. 6, p. $240-242$, pl. 1, figs. $4-6$; pl. 3, fig. 4.

1961. Pseudofusulina globosa, MoriKaWA and Isomi, Geol. Survey of Japan, Rep., No. 191, p. 17, 18, p1. 13, figs. $6-11$.

1961. Pseudofusulina vulgaris var. globosa, KAWANo, Bull. Fac. Educ., Yamaguchi Univ., Mathm. \& Sci., Vol. 11, spec. no. p. 94-96, pl. 6, fig. 20 ; pl. 7, figs. 1-12.

1961. Pseudofusulina vulgaris var. megaspherica, KAwANo, Ibid., p. 96-98, pl. 7, figs. 13-15; pl. 8, figs. $1-5$.

1961. Pseudofusulina cf. globosa var. exilis, Kawano, Ibid., p. 98, 99, p1. 8, fig. 6.

1961. Pseudofusulina vulgaris globosa, Nogami, Mem. Coll. Sci., Univ. Kyoto, Ser. B, Vol. 27, no. 3 , p. 212, 213, pl. 9, figs. $4-7$.

?1961. Pseudofusulina globosa exilis, Nogami, Ibid., p. 214, 215, pl. 9, figs. 10-13.

1963. Pseudofusulina vulgaris var. globosa, CHANG, Acta Palaeont. Sinica, Vol. 11, no. 2, p. 206, 207, p1. 9, fig. 4.

Type.-Toriy Ama (1958, p. 168) designated one of the original syntypes (1909), i. e. the specimen (axial section) illustrated as fig. 3 on pl. 14, as the lectotype of this subspecies (variety at that date). The subspecific distinction of this form is given in page 295.

Material.-Axial section-GK. D 12543 from loc. Ks 45; GK. D 12545, 12626-12628, 12630a from Ks 38, GK. D 12632 from Ks 32, and GK. D 12633 from Ks 33. Sagittal section-GK. D 12629 and 12630b from Ks 38. Some diagonal sections questionably referred to this subspecies came from loc. Ks 44 .

Descriptive remarks.-This subspecies has a highly vaulted median part, pointed poles and commonly concave lateral slopes near the poles. Shells of five to six volu- 
tions attain 7 to $7.8 \mathrm{~mm}$ in length and 5 to $5.5 \mathrm{~mm}$ in width, giving form ratios of $1.4-1.5: 1$.

Proloculus fairly large; its outside diameter measures 490 to 610 microns. Shell expands rapidly. Heights of volutions of the first to the fifth are 250-280, 310-410, 390-610, 370-700 and 370-650 microns, respectively. One sagittal section, in which the precise heights of volutions are determined, gives $28,33,49,51,53$ and 41 microns, respectively for the heights of the first to the sixth.

Spirotheca coarsely alveolar. It distinctly decreases in thickness towards the poles. The thickness above the tunnel is 56-64, 72-88, 100-128, 115-134 and 112-144 microns, respectively in the first to the sixth volution.

Septa intensely and rather irregularly fluted throughout the shell. Septal counts in the first to the fifth volution in a specimen (GK.D 12629) are 10, 19, 27, 27 and 34, respectively. Rudimentary chomata are present only in the first volution.

This subspecies has been distinguished from the typical subspecies by its relatively shorter, more globose form with less extended poles and more convex lateral slopes. In many of the previously figured specimens it has commonly, but not always, better developed phrenothecae and a more irregular septal fluting, and also its lateral slopes are concave near the poles, as in one of the syntypes (SCHELLWIEN and DYRENFUrTH, 1909, pl. 14, fig. 4).

Our specimens are closer to one of the syntypes mentioned above rather than to the lectotype designated by TORIYAMA (1958, p. 168), but a few of them have rather extended poles, approaching the typical subspecies $P$. vulgaris vulgaris.

TORIYAMA (1958) distinguished $P$. vulgaris var. megaspherica (p. 170-172, pl. 22, figs. $8-17$; pl. 23, figs. $1-3$ ) in a sense of subspecific differentiation from $P$. vulgaris vulgaris and $P$. vulgaris globosa, and KAWANO (1961) followed him. We reexamined TORIYAMA's specimens and agree with NoGAMI's opinion in regarding $P$. vulgaris megaspherica as a synonym of $P$. vulgaris globosa. We would also consider, as suggested by NogAmI (1961, p. 215), that Pseudofusulina globosa (DEPRAT) var. exilis (TORIYAMA, 1958 , p. $175-178$, pl. 23 , figs. $7-16$; pl. 24 , figs. $1-20$ ), which is commonly associated with $P$. vulgaris vulgaris and $P$. vulgaris globosa, is a variation within $P$. vulgaris globosa, although TORIYAMA referred to his $P$. globosa exilis the specimens which have a larger proloculus and higher chambers for the corresponding volutions than those of the later two.

Occurrence.-Abundant at locs. Ks 32 and 38 in Member Sc and loc. Ks 45 in Member Sd. Associated species are shown in Table 1.

\section{Pseudofusulina ambigua (DEPRAT) \\ Pl. 44, Figs. 8-10}

1913. Fusulina ambigua Deprat, Mém. serv. géol. Indochine, Vol. 2, fasc. 1, p. 14, 15, pl. 3, figs. 4-7. (Not 1914. Fusulina ambigua, Deprat, Ibid., Vol. 3, fasc. 1, p. 16, pl. 2, figs. 1-4)

1925. Schellwienia ambigua, OzAwA, Jour. Coll. Sci., Imp. Univ. Tokyo, Vol. 45, art. 6, p. 31, pl. 4 , fig. 8.

31927. Schellwienia ambigua, OzAwa, Jour.Fac. Sci., Imp. Univ. Tokyo, Sect. II, Vol. 2, pt. 3, p. 145 , pl. 35 , fig. 7 ; pl. 37 , figs. 2 , 4 ; pl. 38 , fig. $1 \mathrm{a}$; p1, 39 , fig. 10 ; pl. 45 , figs. 7,8 . 
1936. Pseudofusulina ambigua, Huzimoto (Fujimoto), Sci. Rep. Tokyo Bunrika Daigaku, Sect. C, Vol. 1, p. 69, 70, pl. 9, figs. 5, 6; pl. 10, figs. 1-3.

1957. Pseudofusulina ambigua, KoвayAshi, Sci. Rep. Tokyo Kyoiku Daigaku, Sect. C, Vol. 5, p. 271, 272, pl. 5, figs. $9-10$; pl. 6 , figs. $1,2$.

?1958. Pseudofusulina ambigua, Morikawa, Sci. Rep. Saitama Univ. Ser. B, Vol. 3, no. 1, p. 98, 99, p1. 12, figs. 10-14.

1958. Pseudofusulina ambigua, Toriyama, Mem. Fac. Sci., Kyushu Univ., Ser. D, Vol. 7, p. 186-190, p1. 28, figs. 1-15; p1. 29, figs. 1-9.

1959. Pseudofusulina ambigua, Kanuma, Bull. Tokyo Gakugei Univ., Vol. 10, p. 68, 69, pl. 6, figs. $8,9$.

Lectotype.-Of Deprat's three syntypes the axial section of fig. 4 on plate 3 was designated by Toriy Ama (1958, in the explanation of plate 28 ) as the lectotype. The other syntypes are also of identical species.

Material.-Four axial (GK. D 12551a, 12552a, 12553, 12556), three sagittal (GK. D 12552b, 12554, 12555), six tangential and several other oblique sections from loc. Ks 42 . Most of them are more or less deformed.

Remarks.-This species was thoroughly described by previous authors. The diagnostic features of the types. (DEPRAT, 1913, pl. 3, fig. 4-7) are the fairly large, uniformly expanded fusiform shell attaining 8 to $10 \mathrm{~mm}$ in length and about $3 \mathrm{~mm}$ in width, with gently convex lateral slopes, sharply pointed poles in the inner volutions. and bluntly pointed poles in the outer, the rather thick spirotheca with a coarsely alveolar keriotheca, the chambers which distinctly increase in height polewards, and the narrowly fluted septa. In addition secondary deposits fill chambers in the axial regions of the inner volutions and thicken the septa in the median part.

Our specimens agree with the types in these characteristics and dimensions, although they have slightly denser secondary deposits.

Occurrence.-Common at loc. Ks 42 in Member Sd.

\section{Pseudofusulina kraffit (SCHELLWIEN and DyRENFURTH)}

1909. Fusulina kraffi Schellwien and Dyrenfurth, Palaentogr., Vol. 56, p. 169, pl. 13, figs. 1-6; p1. 16, figs. 1-9.

1914. Fusulina tenuissima, Deprat, Mém. serv. géol. Indochine, Vol. 3, fasc. 1, p. 12, 13, p1. 2, figs. 9, 10.

1925. Schellwienia kraffi, OzAwA, Jour. Coll. Sci., Imp. Univ. Tokyo, Vol. 15, art. 6, p. 25-27, pl. 6, fig. 7 ; pl. 7 , fig. 4.

1927. Schellwienia kraffti, OzAwA, Jour. Fac. Sci., Imp. Univ. Tokyo, Sect. II, Vol. 2, pt. 3, p. 147, text-fig. 5a-c.

?1936. Pseudofusulina kraffti, Huzimoto, Sci. Rep. Tokyo Bunrika Daigaku, Sect. C, Vol. 1, no. 2, p. 80,81 , pl. 14 , figs. $3-8$.

1955. Pseudofusulina kraffti, Morikawa, Sci. Rep. Saitama Univ., Ser. B, Vol. 2, no. 1, p. 94, 95, p1. 7, figs. 15-17.

1955. Pseudofusulina motohashii Morikawa, Ibid., p. 101-103, pl. 12, figs. 1-9.

1958. Pseudofusulina kraffti var. magna ToriYama, Mem. Fac. Sci., Kyushu Univ., Ser. D, Vol. 7, p. 178-181, pl. 25, figs. 1-10; pl. 26, figs. 1-15.

1959. Pseudofusulina kraffit, Kanuma, Bull. Tokyo Gakugei Univ., Vol. 10, p. 70, 71, pl. 7, figs. 1-3, 6 .

1959. Pseudofusulina kraffti var. magna, IGo, Sci, Rep. Tokyo Kyoiku Daigaku, Sect. C, No. 56 , p. 244 , pl. 1 , fig. 8 ; pl. 3 , fig. 3 . 
1959. Pseudofusulina kraffti norikurensis IGo, Ibid., p. 244, p1. 2, figs. 1-3.

1961. Pseudofusulina kraffti magna, Nogami, Mem. Coll. Sci., Univ. Kyoto, Ser. B, Vol. 27, no. 3, p. 216, 217, pl. 10, figs. $1-4$.

1961. Pseudofusulina kraffti form A Nogami, Ibid., p. 217-219, pl. 10, figs. 5-8.

1963. Pseudofusulina kraffti, Sheng, Palaeont. Sinica, N.S., B, No. 10, p. 65, 191, p1. 16, figs. 16-18.

1963. Pseudofusulina kraffti, ChAng, Acta Palaeont. Sinica, Vol. 11, no. 2, p. 206, pl. 4, fig. 11.

?1963. Pseudofusulina kraffti var. magna, Chang, Ibid., p. 206, p1. 5, figs. 10, 11, 13.

Type.-Previous authors did not designate the type of this species but DyRENFURTH (1909) noted in Monographie der Fusulinen, Theil II, that the specimen of the axial section illustrated as fig. 1 on plate 16 was typical for the species. To conform his intension we designate it as the lectotype of the present species. The other syntypes are also of identical species.

Diagnosis.-Shell of 5 to 7 volutions, short subcylindrical, commonly with broadly rounded poles. Proloculus moderate to fairly large. Shell expands rather rapidly. Spirotheca thick, coarsely alveolar. Septal fluting reaches almost tops of chambers in lateral regions but low and weak in central region. Dense axial fillings may occur in axial regions of middle-aged volutions. No distinct chomata develop except in inner one or two volutions.

Remarks.-The illustrated original specimens of this species include two forms, a subcylindrical form, which was mentioned by SCHELLWIEN and DYRENFURTH (1909) as typical, and the other short thick one. TorIYAMA (1958, p. 179, 180) distinguished the examples from the Akiyoshi region as P. kraffti var. magna in a sense of subspecific distinction at the present date and designated the specimen of fig. 1 on pl. 25 as the holotype. This form is identical with the short thick form by ScHELLWIEN in DYRENFURTH (1909) and has a relatively thicker and shorter shell, a thicker spirotheca and a larger proloculus than those of the type of $P$. kraffti, and is subspecifically distinguishable from the latter.

IGo (1959, p. 244) has separated subspecifically the examples from the Hirayu Formation of the Hida Mountains as P. kraffti norikurensis (holotype pl. 2, fig. 1). This form is distinguished from the two forms mentioned above in its thick fusiform shell and pointed poles. It is closer to $P$. kraffi magna than to the typical subspecies. The specimens described by IGO at the same time as $P$. kraffti magna are nothing but those of diagonal sections of $P$. kraffti norikurensis.

\section{Pseudofusulina kraffti kraffti (SCHELLWIEN and DYRENFURTH)}

P1. 44, Fig. 7

For synonymy and type see page 299-300.

Material.-An axial section (GK.D 12584a) and many other diagonal and oblique sections from loc. Ks 27 . All of them are almost completely replaced by secondary mineralization.

Descriptive remarks.-Shell short subcylindrical, with broadly rounded poles. A specimen of six and a half volutions about $9 \mathrm{~mm}$ long and $3.7 \mathrm{~mm}$ wide, giving a form ratio of about 2.4. Poles of the inner volutions bluntly pointed. Central part of the mature shell straight to slightly concave. 
Proloculus measures commonly 450 to 550 microns, rarely attaining 700 microns, in its outside diameter. Shell expands uniformly. Heights of volutions in the first to the sixth of a specimen 114, 164, 225, 307, 328 and 369 microns, respectively. Radius vectors of the same volutions $328,492,670,984,1312$ and 1681 microns, respectively. Each chamber increases in height gradually in the lateral part of the shell but rapidly in the end areas.

Spirotheca thick and coarsely alveolar. Thickness of the spirotheca of the first to the sixth volution $82,102,164,205,328$ and 287 (?) microns, respectively.

Septa regularly fluted, but the fluting is weak and low in the central part of the shell. Dense secondary deposits fill the chambers in the axial regions and thicken the septa throughout the shell.

The obtained specimens have a slightly thicker shell than the type of P. kraffti kraffti and approach $P$. kraffti magna in the shell-shape. However the rate of expansion of the shell and the thickness of the spirotheca agree quite well with those of the typical subspecies.

Occurrence.-Abundant at loc. Ks. 27 in the upper part of Member Sc.

\section{Pseudofusulina fusiformis (SCHELLWIEN and DyRENFURTH)}

$$
\text { P1. 52, Figs. 1-6 }
$$

1909. Fusulina vulgaris var. fusiformis SchlLwien and Dyrenfurth, Palaeontgr., Vol. 56, p. 165, pl. 15, figs. 1-3. (not fig. 4)

1948. Pseudofusulina fusiformis, Thompson, Univ. Kansas Paleont. Contr., Protozoa, Art. 1, pl. 12, fig. 3.

1955. Pseudofusulina fusiformis, Morikawa, Sci. Rep. Saitama Univ., Ser. B, Vol. 2, no. 1, p. 98,99 , pl. 13, figs. $1-7$.

1955. Pseudofusulina huecoensis, Morikawa, Ibid., p. 96-98, pl. 13, figs. 8-11.

?1958. Pseudofusulina vulgaris var. fusiformis, Kanuma, Bull. Tokyo Gakugei Daigaku Univ., Vol. 10, p. 75, 76, pl. 7, figs. 7-11.

1959. Pseudofusulina fusiformis, IGo, Sci. Rep. Tokyo Kyoiku Daigaku, Sect. C, Vol. 6, p. 246, 247, pl. 3, fig. 5 .

1961. Pseudofusulina fusiformis, MoRiKawa and Isomi, Geol. Survey of Japan, Rep., No. 191, p. 19 , 20, pl. 7, figs. 11,12 ; pl. 8 , figs. 12 , 13 ; pl. 10, figs. $1-10$; pl. 11, figs. $1-10$; pl. 12, figs. $1-10$; pl. 13, fig. 5 .

?1962. Schwagerina fusiformis, SuYARI, Jour. Gakugei, Tokushima Univ., Nat. Sci., Vol. 12, p. 26, pl. 8, figs. 7-9.

?1962. Parafusulina fukasensis SuYARI, Ibid., p. 28, pl. 9, figs. 1-4.

Lectotype.-The specimen illustrated as fig. 2 on plate 15 by SCHELLwIEN and DYRENFURTH (1909), designated by THOMPSON [1948, p. 52, for the reproduced figure (pl. 12, fig. 3, noted as the holotype)]. The other syntypes, except the specimen of fig. 3 on pl. 15, are also of identical species.

Material.-Axial section-GK.D 12712, 12715 and 12716 from loc. Ks 39; GK.D 12579, 12580 from Ks 44 and GK. D 12581-12583 from Ks 45 . Sagittal section-GK. D 12714 c from Ks 39. Several other oblique sections from locs. Ks 39, 44 and 45. Most of them are secondarily elongated along the axis of coiling.

Description.-Shell fairly large, subcylindrical, with rounded poles. Among the obtained specimens, better preserved ones attain 8.5 to $11 \mathrm{~mm}$ in length and 2.6 to 
$3.8 \mathrm{~mm}$ in width in five to six and a half volutions. Form ratios 2.9 to 3.3. Proloculus spherical, measuring 410 to 472 microns in its outside diameter. Shells coiled loosely but uniformly. Heights of volutions in the first to the fifth of four specimens are 103-144, 103-184, 205-246, 287-328, and 287-355 microns, respectively. Radius vectors of the first to the sixth volution in two comparatively better preserved specimens are 328-369, 451-553, 615-779, 943-1086, 1272-1394 and 2173 microns, respectively. Heights of chambers are about the same in the central half of the shell and increase rapidly as the poles are approached.

Spirotheca very thick, finely alveolar in the inner three volutions but becomes fairly coarse in the outer. Its thickness measures $45-48,56-64,72-80,80-112,96-120$ and 120 microns, respectively in the first to the sixth volution of four specimens.

Septa weakly fluted in the central half of the shell, but in the lateral and polar regions the fluting reaches the tops of the chambers. Septal counts can not be given because of the lack of sagittal sections.

Small chomata occur in inner two volutions.

The development of secondary deposits in the axial regions is very variable between individuals. In some specimens the axial deposits are wide and dense, but in some others narrow and confined to the inner two volutions and only thicken the septa in outer ones. The examples of both extremities are shown as Figs. 1 and 3 on Plate 52.

Remarks and comparisons.-The types of Pseudofusulina fusiformis from Darwas are diagnostic in the fairly large subcylindrical shell, the large proloculus, the weak septal fluting in the central part of the shell and the thick septa with coatings of secondary deposits.

Our specimens agree closely with the types of the species in the above mentioned characteristics and also in the measurements. LEE (1927) regarded Fusulina vulgaris var. fusiformis SCHELLwIEN and DyRENFURTH from Darwas as a distinct species from "Schellwienia" vulgaris and erected a new species "Schellwienia" valida on it and also on the Chinese specimens, without designating the holotype. As already stated by NogAmi (1961, p. 222-223), Pseudofusulina valida (LEE) is a subjective synonymy of $P$. fusiformis (SCHELLWIEN and DYRENFURTH). However, a question remains whether $P$. valida (LEE) from China is conspecific with $P$. fusiformis from Darwas. In this connection IGo (1959, p. 242, 247), MorikAWA (1961, p. 13), CHISAKA (1962, p. 542) and CHANG (1963, p. 205) separated $P$. valida from $P$. fusiformis as a different species.

One of LEE's specimens of $P$. valida (1927) illustrated as fig. 2 on plate 8 is closely similar to the types of $P$. fusiformis, but it has thinner and more strongly fluted septa even in the central part of the shell. Another axial section of $P$. valida illustrated as fig. 10 on the same plate has much thinner spirotheca and septa and is not similar to $P$. fusiformis. LEE's specimens should be restudied, but we would rather agree with IGo in separating $P$. valida from $P$. fusiformis as a different species.

Occurrence.-Common at locs. Ks 39, 44 and 45 in Member Sd. 


\section{Pseudofusulina sp. aff. P. japonica (GÜMBEL)}

P1. 53, Figs. 1-6

Compare.-

1874. Fusulina japonica GüMBEL, Japanesischen Gestein. Das Ausland, Stuttgart, Jg. 47; p. 479.

1883. Fusulina japonica Gümbel, Schwager, Richthofen’s China, Bd. 4, p. 121-124, pl. 15, figs. 1-10.

1906. Fusulina japonica, YABE, Jour. Coll. Sci., Imp. Univ. Tokoy, Vol. 21, art. 5, pl. 2, fig. 1.

1914. Fusulina japonica, Deprat, Mém. serv. géol. Indochine, Vol. 3, fasc. 1, p. 7-9, pl. 1, figs. 1-9.

?1915. Fusulina japonica, Deprat, Ibid., Vol. 4, fasc. 1, p. 7, 8, p1. 1, figs. 17, 19. (probably referable to P. japonica akasakensis DePRAT) (Not figs. 18, 20).

?1924. Fusulina japonica, Colani, Ibid., Vol. 11, fasc. 1-2, p. 9-12, 136, 7, pl. 7, figs. 1-12, 14-29. (Not fig. 13) ; pl. 8, fig. 1, 2, 4, 5. (Not figs. 3, 9-13).

1925. Schellwienia japonica, OzAwA, Jour. Coll. Sci., Imp. Univ. Tokyo, Vol. 45, art. 6, p. 30.

1927. Schellwienia japonica, OzAwa, Jour. Fac. Sci., Imp. Univ. Tokyo, Sect. 2, Vol. 2, pt. 3, p. 147-149, pl. 36, figs. 1-7; pl. 37, fig. 7a.

?1927. Schellwienia japonica, LeE, Palaeont. Sinica, Ser. B, Vol. 4, fasc. 1, p. 82-85, pl. 13, figs. 1-8.

?1934. Parafusulina japonica, CHEN, Ibid., p. 81, 82, p1. 6, figs. 1, 9; p1. 8, fig. 7 .

1936. Pseudofusulina japonica, Huzimoto (Fujimoto), Sci. Rep. Tokyo Bunrika Daigaku, Sect. C, Vol. 1 , no. 2, p. 56-59, pl. 5, figs. $8-10$; pl. 6 , fig. 3.

1955. Schwagerina japonica, Morikawa, Sci. Rep. Saitama Univ., Ser. B, Vol. 2, no.1, p. 106, 107, pl. 14, figs. 11, 12.

1957. Schwagerina japonica, KoBAyAshi, Sci. Rep. Tokyo Kyoiku Daigaku, Sect. C, Vol. 5, no. 48 , p. $285-287$, pl. 6 , figs. $3-5$.

1958. Parafusulina japonica, Morikawa, Sci. Rep. Saitama Univ., Ser. B, Vol. 3, no. 1, p. 112-114, pl. 19, figs. 1-7.

1962. Parafusulina japonica, SuYARI, Jour. Gakugei, Tokushima Univ., Nat. Sci., Vol. 12, p. 29, pl. 10, figs. $1-2$.

Type of Pseudofusulina japonica.-GüMBEL (1874) did not give the illustration of the original specimens. The specimens are to have been kept in "Königliches Mineralogisches Museum an der Universität in Berlin". Unfortunately ScHWAGER's figured specimens were not well oriented and very poor. Anyone who is accessible to the original syntypes should select the lectotype and redescribe the species.

Material.-Axial section.-GK.D 12548a from loc. Ks 29; 12550 from Ks $31 ; 12593$ from Ks 36; 12597 from Ks 37; 12634a from Ks 38; 12635 from Ks 33 . Sagittal section.-GK. D 12547b, 12587a and b from loc. Ks 29; 12634b from Ks 38. Tangential section.-GK. D 12547a, 12548b, 12549, 12589 and 12590 from Ks 29. Several other diagonal sections are also included in this species.

Description.-Shell fusiform with nearly flat median part, usually straight or, slightly concave lateral slopes and bluntly pointed poles. Shells of six to six and a half volutions attain 11 to $13 \mathrm{~mm}$ in length and 4.0 to $4.5 \mathrm{~mm}$ in width, giving form ratios of 2.7 to 2.8 .

Proloculus ranges from 360 to 380 microns in its outside diameter. Shells expand uniformly but rather rapidly. Heights of volutions which show a somewhat wide extent of variation in inner volutions are $110-160,200-230,270-325,300-338,345-370$ and 400-415 microns for the first to the sixth volution, respectively. Height of each 
chamber is almost equal in the median part of the shell, but increases gradually polewards.

Spirotheca, which is fairly coarsely alveolar, measures $56-64,64-80,64-96,90-120$, 120-125 and 104-112 microns in the first to the sixth volution, respectively. Septa regularly and strongly fluted throughout the shell. Septal fluting reaches nearly the tops of the chambers usually with steep or almost vertical sides and flat crests. Low cuniculi is developed in outer volutions. Phrenothecae occur in part.

Fairly dense secondary deposits fill the chambers in the axial regions of the first to the fourth volution and thicken the septa almost throughout the shell except in the polar regions of the outermost volution. Tunnel narrow, being about $34,26,20$ and 18 degrees in the second to the sixth volution of a specimen.

Comparisons and remarks.-This species is most closely similar to Pseudofusulina japonica by SCHWAGER (p1. 15, figs. 1-10). P. japonica was identified from various areas and DEPRAT's specimens (1915, p. 7-9, pl. 1, figs. 1-9) from the Akasaka Limestone may be the closest to the types, and OzAWA's (1927, pl. 36, figs. 1-7; pl. 36, figs. 7a) and MoRIKAWA's (1958, pl. 19, figs. 1-7) from the same limestone and KoBAYASHI's (1957, pl. 6, figs. 3-5) from the Ibukiyama Limestone are also very close to the types. The specimens identified by other authors may not be referable to the species as already pointed out by MoRIKAWA (1958, p. 114). The incompleteness of the original illustration has given rise to much confusion for identification of the species and the uncertainty of the information as to the type locality of the species restrains us from collecting and examining of the topotypes. It is indispensable, therefore, to restudy the original types in the Museum of Mineralogy, University of Berlin.

This species has been known to range from the Pseudofusulina vulgaris zone to the Neoschwagerina craticulifera zone.

The present specimens are not probably conspecific with the specimens identified by Deprat (1914), Ozawa (1927), Kobayashi (1957) and Morikawa (1958), and their spirotheca are much thicker than those of the latters for the corresponding volutions, especially in the inner volutions, but are nearly equal to those of ScHWAGER's figures.

Occurrence.-Abundantly found at loc. Ks 29, commonly at Ks 36, 37 and 38, and rarely at Ks 31 and 33. All from the lower part of Member Sc.

\section{Pseudofusulina sp.}

P1. 45, Figs. $6-9$; P1. 50, Fig. 8

Material.-Axial section-GK. D 12554, 12571a, 12572, 12573a, 12577a and b; Sagittal section-12555, 12571b, 12574a and b, 12576. There are many other diagonal and tangential sections which are probably referable to this species. All from loc. Ks 42 . All the specimens are more or less deformed.

Description.-Shell elongate subcylindrical, with bluntly pointed to narrowly rounded poles, attaining 8 to $12.5 \mathrm{~mm}$ in length and 1.8 to $2.8 \mathrm{~mm}$ in width in four to six volutions. Although most of the axial sections are more or less deformed, approximate form ratios range from 3.6 to 5.0 .

Proloculus mostly spherical to subspherical, large, commonly 370 to 500 microns in its outside diameter; the largest one attains 738 microns. Shell expands uniformly, 
but the specimens which have a relatively large proloculus show in general more rapid expansion of the shell in the inner volutions than in those which have a smaller ones. Heights of volutions in the first to the fourth are 82-144, 123-205, 185-246 and 205-246 microns, respectively. Chambers gradually increase in height polewards.

Spirotheca thin, rather finely alveolar. Thickness of spirotheca in the first to the fourth volution is mostly 24-35, 32-55, 45-64 and 64-75 microns, respectively, but that of a specimen is $48,80,80$ and 96 microns, respectively for the corresponding volutions.

Septa fluted throughout the shell, and the fluting is rather irregular and very low in the central part of the shell but reach almost the tops of the chambers in the lateral areas. Septal counts in the first to the fourth volution of three specimens are 8-9, 15-16, 15-20 and 17-20, respectively.

Secondary deposits not uncommonly thicken the septa and sometimes fill chambers in the axial region. Small and low chomata are present in inner two volutions.

Remarks and comparisons.-As the shells, especially of the outer volutions of the present species, are secondarily elongated along the direction of the axis of coiling, they can be interpreted as originally much inflated and their spirotheca of the outer volutions thicker.

This species is diagnostic in the subcylindrical shell, relatively thin spirotheca and rather irregular and very low septal fluting in the central part of the shell. It is similar to Pseudofusulina parumvoluta (DEPRAT, 1913, p. 12, 13, pl. 2, figs. 10-13; pl. 3, fig. 1) from Laos, but the precise comparison can not be made because the illustrated axial sections of the latter is not well oriented.

This species is also similar to Rugosofusulina arctica (SCHELlwien, 1898, p. 173, 174, pl. 16, figs. 3-9) from the Carnic Alps, but it has a larger shell and a larger proloculus. It may belong to a new species, but the material is so poor that we postpone to establish a new species until better specimens are obtained.

Occurrence.-Abundant at loc. Ks 42 in Member Sd.

\section{Genus Schwagerina von MöLLER, 1878}

Type-species.-Borelis princeps EHRENBERG, 1842

Schwagerina sp. aff. S. compacta (WHITE)

Pl. 48, Figs. $12-15$

Compare.-

1932. Triticites compactus White, Univ. Texas Bull., 3211, p. 38, 39, pl. 2, figs. 10-15.

1937. Schwagerina compacta, Dunbar and SKinner (partim), Ibid., 3701, p. 645, 646, pl. 64, figs. 1-8 (not pl. 65, fig. 16).

1963. Schwagerina compacta, SHENG, Palaeont. Sinica, N.S. B, No. 10, p. 184, pl. 14, fig. 18 ; pl. 21, figs. 9-11.

1963. Schwagerina compacta, Ross, Geol. Soc. Amer. Mem., 88, p. 117, 118, p1. 16, figs. 9-12.

Lectotype of S. compacta.-WHITE's original specimens illustrated as fig. 11 on plate 2 (1932) (reillustrated by DUNBAR and SkinNeR, 1937, pl. 64, fig. 5), as designated by Ross (1963, p. 118).

Material.-Axial sections-GK. D 12603, 12604 from loc. Ks 30 ; 12601a and b from 
Ks 34. Tangential sections which pass through near the proloculus: GK.D 12602 from loc. Ks 28, GK. D 12598a and b, 12599 and 12600 from Ks 34. More or less deformed.

Descriptive remarks.-Shell thick fusiform, commonly with a subcylindrical median part and convex to straight lateral slopes tapering towards subarcute poles. Shells of six to seven volutions attain 6.5 to $9 \mathrm{~mm}$ in length and 2.5 to $3.6 \mathrm{~mm}$ in width. Approximate form ratios 1.6 to 2.6 .

Proloculus 160 to 260 microns in outside diameter. Heights of the volutions of the first to the sixth are 82 (?), 102-123, 142-164, 183-205, 246-266 and 266-287 microns, respectively. Radius vectors of the same volutions are 184(?)-205, 287-328, 430-533, 623-738, 881-943 and 1108-1330 microns, respectively. Chambers increase in height gradually towards the poles.

Spirotheca thin, rather coarsely alveolar in outer volutions. Thickness of the spirotheca is $32,40,32-48,50-56,64-70$ and 80 microns, respectively in the first to the sixth volution.

Septa strongly and regularly fluted throughout the shell, and the fluting reaches. almost the tops of the chambers even in the central part of the shell, with steep sides and flat crests. Due to lack of well-oriented sagittal section septal counts can not be given.

Secondary deposits fill the axial regions of the second to the outer volutions except in the last one, and thicken the septa especially in the lateral slopes. Rudimentary chomata may occur in the first two volutions.

This species is diagnostic in the thick fusiform shell with a subcylindrical median part and lateral slopes tapering toward subacute poles, the thin spirotheca with fairly coarse alveoli, the uniform expansion of the shell, the regular septal fluting and the dense axial fillings.

The present specimens are very close to the types of $S$. compacta (WHITE) from Glass Mountain, Texas, in the above mentioned characteristics. Although precise character of the juvenarium of the present specimens in hardly observed because of poor preservation, they appear to have a slightly larger proloculus and higher chambers for the corresponding inner volutions. Ross (1963, p. 117) noted that the septal folds of S. compacta have flat crests. Those of the present specimens exhibit a very similar nature, but have more regularly and distinctly flat crests.

This species is also similar to S. ahlfeldi DUNBER and NEwELL (1946, p. 462-464, pl. 3, figs. 1-10) from Central Andes and to S. formosa Kochansky-Devidé (1959, p. 51, pl. 1, figs. 23-26) from South Kroatia. It differs, however, from S. ahlfeldi in its much longer shell and from $S$. formosa in its larger shell and more regularly fiuted septa.

Occurrence.-Abundant at locs. Ks 34, 28 and 30 in Member Sc. Some specimens referred with a query to this species were obtained from loc. Ks 37 of Member Sc. Associated species are given in Table 1.

\section{Schwagerina sp.}

P1. 52, Fig. 7

Material.-One axial (GK.D 12559), one sagittal (GK.D 12618c), two tangential (GK. D 12558c and 12619b) and several other oblique sections from a collection at loc. 
Ks 18.

Description.-Shell fusiform with parallel or slightly concave median part and conical lateral sides. Shells of 5 to 6 volutions are 8 to $8.5 \mathrm{~mm}$ long and about $3.5 \mathrm{~mm}$ wide.

Proloculus 245 to 370 microns in its outside diameter in three specimens. Shell expands uniformly. Heights of the volutions of the first to the fifth of a sagittal section are 164, 210,287, 370 and 370 microns, respectively.

Spirotheca finely alveolar. Its thickness of the first to the fifth volution is 32 , 40-48, 48-64, 56-80 and 64-96 microns, respectively. Septa weakly fluted in inner two volutions, but strongly and rather regularly fluted in outer volutions. Septal counts of the first to the fifth volution are 11,18 ?, 21, 26? and 26?, respectively.

Rudimentary chomata occur in inner three volutions. Dense deposits fill the chambers in the axial regions and the lateral shoulder areas of the inner four or five volutions.

Comparisons.-The present species is similar to Schwagerina guembeli DuNBER and Skinver (1937, p. 639, pl. 61, figs. 1-13) and S. gumbeli pseudoregularis DunBer and SkINNER (1937, p. 640, pl. 61, figs. 14-24), but it has a slenderer shell and denser secondary deposits.

CHAO (1963) identified Pseudofusulina kraffti magna ToRrYAMA from the "Upper Carboniferous" of the Tsinghai province, China (p. 206, pl. 5, figs. 10, 11, 13), but his specimens do not seem to be referable to the species in their thinner shell, thinner spirotheca for the corresponding volutions and smaller proloculus. The present specimens are very similar to them, but better oriented sections are needed for the precise comparison.

Occurrence.-Common at loc. $\mathrm{Ks} 18$ in Member $\mathrm{Sb}_{2}$.

Genus Nagatoella Thompson, 1936

Type-species.-Nagatoella orientis. THOMPSON, $1936[=$ Fusulina (Schellwienia) ellipsoidalis var. orientis OzAWA, 1925]

Nagatoella minatoi sp. nov.

P1. 50, Figs. 9-11; P1. 53, Figs. 7-9

1952. Waeringella? sp. Toriyama, Mem. Fac. Sci., Kyushu Univ., Ser. D, Vol. 3, no. 3, p. 132 , pl. 3 , figs. 3,4 .

Material.-Holotype GK. D 12718 (axial section, P1. 53, Fig. 7); Paratypes, GK. D 12713a, 12714a (P1. 53, Fig. 9), 12714b (Pl. 50, Fig. 9), 12717a (Pl. 53, Fig. 8), 12717b (Pl. 50, Fig. 11), 12712, 12713b (P1. 50, Fig. 10). All from loc. Ks 39. Some incomplete specimens from locs. Ks 44, 50 and 39 are also referred to this species. All specimens are more or less deformed.

Description.-Shell ellipsoidal to short subcylindrical with broadly rounded poles. Mature specimens of eight to nine volutions are 5.7 to $7.3 \mathrm{~mm}$ long and 2.6 to $3.1 \mathrm{~mm}$ wide. Form ratio ranges from 2.2 to 2.5 .

Proloculus small, 110-115 microns in its outside diameter. Shell tightly coiled in 
inner volutions and uniformly expands throughout the shell. Inner one and a half volutions are subspherical in shape, but beyond the second volution the shell assumes. the mature shape. Heights of volutions in the first to the eighth of the holotype are$46,48,64,96,160,210,258$ and 418 microns, respectively.

Spirotheca finely alveolar. It is less than 25 microns in thickness in inner threevolutions, about 32 microns in the fourth, 64 microns in the sixth, and attains 80 to. 100 microns in outer volutions.

Septa almost plane in the median part of the inner four volutions, but they are fluted across the length of the shell in outer volutions. The fluting is rather regular and is restricted generally to the lower half of the septa, and the crests of the folds are characteristically rounded.

Chomata prominent throughout the growth of the shell. Their tunnel sides are nearly vertical and their poleside-slopes are gentle in inner volutions, but become symmetrical in the outer. Tunnel straight, slit-like in cross-section and as high as a half of the height of the chamber in outer volutions. Tunnel angles are 30-40 degrees in inner three volutions and 45-50 degrees in the outer. No secondary deposits occur.

Remarks and comparisons. - This new species is characterized by an ellipsoidal to a short subcylindrical, uniformly expanded shell with broadly rounded poles, tightly coiled inner volutions, prominent chomata, a almost straight tunnel, and a low and regular septal fluting with rounded crests. These diagnoses justify the assignment of this species to the genus Nagatoella, although no axial fillings as in the type-species of the genus occur.

This species resembles $N$. ikenoensis MoRIKAWA and Isomi (1961, p. 22, pl. 20, figs. 6-13), but it differs in its larger shell and thicker spirotheca for the corresponding volutions. It is similar to Nagatoella sp. from the Kozaki Formation of southern Kyushu (KANMERA, 1963, p. 93, pl. 14, figs.22-24; pl. 19, fig. 13), but it has a larger shell and larger heights of volutions. It is similar to Triticites ordinatus CHEN (1934, p. 38, 39, pl. 7, figs. 5-7) and T. sinensis CHEN (1934, p. 36-38, pl. 7, figs. 8, 12) from the Swine Limestone in South China, which are closely allied to the species of Nagatoella. The former has, however, a more subcylindrical shell and more strongly fluted septa than the latter two.

Occurrence.-Common at loc. Ks 39, rare at Ks 44 and 50. All belong to Member Sd.

\section{Zonation of the type Sakamotozawa Series}

A list of the fusuline species identified by us from the Sakamotozawa Formation, the type sequence of the Sakamotozawa Series, with their stratigraphic distribution, is shown in Fig. 1 and Table 1. The fusuline beds, many of which are well traceable within the surveyed area, are usually teemed with abundant specimens, but the contained species are rather of small number in assemblage and closely related to the lithofacies, as has already mentioned. Each zone in the formation is therefore represented by a limited sequence of strata which is defined by a particular species or a particular assemblage of species and is significantly distinguished from that above and. below. 
In the Sakamotozawa Formation five zones, each of which is denominated with a diagnostic species, are recognized as shown in Fig. 1. Furthermore subzones can be defined by relatively short-ranged species.

(1) Zellia nunosei zone

The main part of Member $\mathrm{Sb}_{1}$ is characterized by the common to abundant occurrence of Zellia nunosei. This zone is well traceable in the Nagaiwa area. IGo (1964). described the species also from the type Sakamotozawa Valley, and mentioned that it occurs throughout the whole sequence of the Sakamotozawa Series, but so far as. our study is concerned, it is restricted to Member $\mathrm{Sb}_{1}$, the lowest part of the Sakamotozawa Limestone.

In this zone Quasifusulina tenuissima occurs abundantly and Rugosofusulina sp. is also commonly found. Nipponitella explicata and Monodiexodina langsonensis, which are characteristic in the succeeding Member $\mathrm{Sb}_{2}$, begin to occur in the upper part of this zone. Many authors reported $Q$. longissima from the Sakamotozawa Limestone of this area, but our specimens of Quasifusulina are all referable to Q. tenuissima.

Minato et al. (1954, p. 282) recorded the occurrence of Pseudoschwagerina from a horizon immediately above the basal conglomerate of the formation, without giving. a specific name.

(2) Monodiexodina langsonensis zone

Member $\mathrm{Sb}_{2}$ is characterized by the abundant occurrence of Monodiexodina langsonensis from the bottom to almost the top. Nipponitella explicata occurs also abundantly in the same member. The two species have almost the same stratigraphic range and they are sometimes found together in the same rock. There are, however, many other cases in which a prolific bed is exclusively teemed with one or the other of the two species.

Species of peculiarly upcoiled Nipponitella, including $N$. explicata, have never been found outside the Kitakami region and appear to be endemic. Therefore in our present knowledge they are of little use for correlation between separated places even within the Japanese province.

In this zone Quasifusulina tenuissima, Paraschwagerina (Paraschwagerina) sp., $R$ ugosofusulina alpina and $R$. rossica are accompanied. Q. tenuissima is restricted to Members $\mathrm{Sb}_{1}$ and $\mathrm{Sb}_{2}$, and never ranges up to younger beds. Paraschwagerina (s. s.). sp. occurs in a definite portion of the middle part of this zone, while $R$. alpina and $R$. rossica are restricted to the upper part ot the same zone.

Unfortunately Member $\mathrm{Sb}_{3}$ is very rare in fusulines. Only fragmentary specimens of Paraschwagerina (Acervoschwagerina) sp. and Schwagerina sp. have been obtained from the lowest part, and accordingly the establishment of a zone with a named species is impossible.

(3) Pseudofusulina vulgaris zone

Pseudofusulina vulgaris vulgaris and $P$. vulgaris globosa are diagnostic in the lower part of Member Sc, but the latter subspecies ranges up to the lowest part of the overlying Member Sd and exceeds in stratigraphic range beyond the designated zone.

Pseudofusulina sp. aff. P. japonica, Rugosofusulina sp. aff. $R$. serrata and Schwagerina sp. aff. S. compacta are also diagnostic in the main part of this zone and $P$. kraffti 
kraffti was found abundantly in a bed of the upper part.

Pseudofusulia vulgaris (s.l.) has been known not only from many places in Japan but also from China, Indochina, Darwas and the Carnic Alps and is diagnostic in a definite stratigraphic unit between the zones which are characterized by species of Pseudoschwagerina (s.s.) below and by those of Parafusulina above. Parafusulina? turgida THOMPSON and WheELer (1946, pl. 4, figs. 1-3) from the McCloud Limestone of California is closely allied to this species and belongs to the same species-group. It is interesting that Parafusulina? calx (Thompson and WheELer, 1946, p. 29, pl. 4, figs. $4-6$; pl. 6, figs. 4, 5) of the same limestone, which occurs from about 110 feet below the P.? turgida horizon, is considerably close to Pseudofusulina sp. aff. $P$. japonica of this zone.

A short remark must be given on this occasion about the occurrence of Pseudoschwagerina (Robustoschwagerina) schellwieni in this zone, which ranges up from the upper part of Member $\mathrm{Sb}_{2}$ of the Lower Subformation. It is not appropriate, therefore, to divide the Sakamotozawa Formation into the Pseudoschwagerina zone below and the Parafusulina zone above simply on the basis of the genus Pseudoschwagerina in such terms as has hitherto been done. Species of $P$. (Robustoschwagerina) have been found at higher horizons than those of Pseudoschwagerina (s.s.) in Russia (RAUSER-CHERNOUSSOVA, 1960, 1962). Likewise in Japan, the coexistence of $P$. $(R$. schellwieni with Pseudofusulina vulgaris and $P$. kraffti is already recorded by IGO (1963) from central Japan.

(4) Pseudofusulina fusiformis zone

The lower three-fifths of Member Sd are characterized by the common occurrence of Pseudofusulina fusiformis and Nagatoella minatoi. Pseudofusulina vulgaris globosa ranges up from the underlying unit Sc to the lower part of this zone, and Toriyamaia laxiseptata also extends up to the top.

(5) Pseudofusulina ambigua zone

In the uppermost of Member Sd there is a definite bed which contains Pseudofusulina ambigua commonly and $P$. sp. abundantly. The recognition of this zone may be insufficient because of the restricted distribution of the limestone in the upper part of Member Sd. However, on the species assemblage and from the stratigraphic position the $P$. ambigua bed is apparently distinct from the underlying zone.

Concluding remarks.-As mentioned in the foregoing paper, a physical break has been ascertained to exist between units $\mathrm{Sb}$ and $\mathrm{Sc}$, by which the Sakamotozawa Formation is divided into the Upper and the Lower Subformation. Although the physical break does not seem to be significant, a remarkable change of species assemblages is recognized at this boundary, as shown in Fig. 1. Most of the species, especially diagnostic ones, of Members $\mathrm{Sb}_{1}$ to $\mathrm{Sb}_{3}$ do not range up to Members $\mathrm{Sc}$ to Sd, and several large species of Pseudofusulina appear in the latters. Only a few long-lived species, such as Minojapanella elongata and Nankinella kawadai, and Pseudoschwagerina (Robustoschwagerina) schellwieni, which appears in the upper part of Member $\mathrm{Sb}_{2}$, extend to the lower part (Sc) of the Upper Subformation. Most of the species of Pseudoschwagerina and Paraschwagerina (s.l.) are confined to the Lower Subformation. 
To sum up, the Sakamotozawa Formation is defined by the successive zones as tabulated in Fig. 1. If we follow a major scheme of Zones defined by generic indices, the Lower Subformation may be regarded as representing the Zone of Paraschwagerina and the Upper one as representing that of Pseudofusulina. Although a species of Pseudoschwagerina (Acervoschwagerina) ranges up across the boundary of the two subformations, species of Pseudofusulina are very characteristic of the Upper Subformation and never occur in the Lower.

\section{Correlation}

\section{A. Correlation within the Japanese lslands}

The three zones as recognized in the Upper Subformation of the Sakamotozawa Formation, the Pseudofusulina vulgaris, $P$. fusiformis and $P$. ambigua zones, contain several species common or closely allied to those of the $P$. vulgaris and the $P$. ambigua zone (TORIYAMA, 1957, 1958) or the $P$. vulgaris globosa zone (HASEGAWA, 1963) of the Akiyoshi Limestone Group, the $P$. vilgaris zone and the lower half of the P. kraffti magna zone of the Atetsu Limestone (NoGAMI, 1964), and the upper part of the Acervoschwagerina zone and the lower part of the P. ambigua zone of the Ibukiyama Limestone (KobAYASHI, 1957) in the Inner Zone of Southwest Japan. The order of the stratigraphic occurrence of the diagnostic species in the three zones is almost the same as that in the corresponding zones of other well studied sections in Southwest Japan.

TORIYAMA $(1957,1958)$ has noted that there is a distinct faunal change between the Pseudofusulina ambigua zone and the superjacent Parafusulina kaerimizensis zone in the Akiyoshi area. Minato et al. (1964) also led nearly the same conclusion. No species of Parafusulina comparable to those of the $P$. kaerimizensis zone of the Akiyoshi and Atetsu areas and the $P$. sapperi zone of the Ibukiyama area have been found from the Sakamotozawa Formation. MinAto et al. (1964) have reported Misellina claudiae from the uppermost part of the Sakamotozawa Limestone. In many areas of Southwest Japan a particular zone of $M$. claudiae is found beneath the Parafusulina kaerimizensis zone or the upper part of the Pseudofusulina ambigua zone (KANMERA, 1963).

Monodiexodina matsubaishi (Fujıмотo), which has a large subcylindrical shell and highly fluted septa as in typical species of Parafusulina, has been known to occur from the superjacent Kanokura Formation (FuJIMoTo, 1965; ONUKI, 1956; Minato et al., 1959). Minato et al. (1964) have defined the lower part of the Kanokura Formation as the Monodiexodina zone and suggested the existence of an unconformity beneath the basal conglomerate of the formation. Murata (1964, p. 20) noted, however, that the species occurred also from tho Motoizawa Sandstone and the top of the Shiratorizawa Limestone (a local name for the Sakamotozawa Limestone) of the Sakamotozawa Formation in the Kanokura area, about $15 \mathrm{~km}$ west of Sakamotozawa. Whether or not this species actually ranges down to the Sakamotozawa Formation in that area remains to be studied. Anyhow, the Sakamotozawa Formation does not extend up in stratigraphic level as high as the Parafusulina kaerimizensis zone or the corre- 
sponding $P$. sapperi zone even in its upper part.

On the grounds of the stratigraphic position subjacent to the widespread $P$. vulgaris zone and from the dominant occurrence of Zellia, Pseudoschwagerina and Paraschwagerina, the Lower Subformation is obviously referred to the lower part of the Lower Permian in Southwest Japan, as has been previously (Minato et al, 1954; ONUKI, 1956, etc.) considered. However, noteworthy is the fact that the Lower Subformation is characterized by particular assemblages of fusuline species which are largely different from those of the so-called Pseudoschwagerina zone in Southwest Japan. This may not be due to the difference of the faunal province, but probably depends much on the particular environmentel conditions. This interpretation is supported by particular sedimentary facies of the Sakamotozawa Limestone, as described in the foregoing paper, which is very different from those of the correlatives of other areas in Japan.

Of the species from the Lower Subformation the diagnostic species, i. e. Nipponitella explicata is an endemic faunal element of the Kitakami region, so far as is known. Zellia nunosei has a restricted distribution and, outsides the Kitakami region, it has been recorded from only one place of the Kusanogawa area, east of Lake Biwa (MORIKAWA and ISOMI, 1961). Monodiexodina langsonensis is similar to M. linealis from the Wolfcamp Formation, M. alaskensis from the Kiui Island, Alasaka, M. pailensis from the Lower Productus Limestone of the Salt Range, and $M$. prolongada from Bolivia. It has, however, a weaker septal fluting and a smaller shell than these species.

Rugosofusulina alpina was described from only a few areas [Ichinotani, Hida mountains (IGo, 1956); Kwanto mountains (Нujimoto, 1936)], but we doubt the correctness of the identification (also refer NoGAMI, 1961, p. 196). R. rossica has never been described from any other areas of Japan. Species of Quasifusulina recorded from various areas, including the Kitakami, have been referred to either $Q$. longissima longissima or Q. longissima ultima. Specimens of Quasifusulina in our collection from the Sakamotozawa Formation of the surveyed area are, however, all referred to $Q$. tenuissima. Species of Pseudoschwagerina and Paraschwagerina (s.s.) were unfortunately undetermined because of incomplete preservation.

To sum up, few species from the Lower Sakamotozawa Formation are common to those from other areas of Japan. In addition to this fact, it should be noted that the zones are devoid of species of Triticites. In connection with this fact, some remarks must be given about the basal part of the Permian below the Pseudofusulina vulgaris zone of Southwest Japan. Nogami (1965) subdivided the basal part of the Permian of the Atetsu area into the Quasifusulina longissima ultima subzone below and the Pseudoschwagerina subsphaerica subzone above. The former contains, besides " Pseudoschwagerina" nakazwai, many small species of Triticites which are characterized by weakly fluted septa, such as T. ozawai, T. haydeni, T. sp. A, etc., and the latter is characterized by Pseudoschwagerina saigusai, $P$. subsphaerica, Paraschwagerina kanmerai, Schwagerina primigena, Pseudofusulina atetsuensis, etc., and most of the species of Triticites in the subjacent zone do not extend up to this zone. In the Akiyoshi area the Triticites simplex zone lies below the P. vulgaris zone (TORIYAMA, 1957 ; 1958). HASEGAWA (1963) subdivided it into two subzones, the T. simplex subzone 
below and the Pseudoschwagerina muongthensis subzone above. In this zone, throughout the two subzones, many species of small Triticites such as the species mentioned above predominantly occur. However, in HASEGAWA's $P$. muongthensis zone there appear Schwagerina sp. cfr. S. satoi, Paraschwagerina sp. cfr. P. akiyoshiensis and Pseudofusulina regularis in addition to the index species of the subzone. This relation. is essentially in harmony with what is recognized in the Atetsu area, although the species are not always conspecific. Similar relation has already been clarified in the lowest part of the Permian section of the Yayamadake Limestone in Kyushu (KANMERA, 1953; 1955).

The above discussion leads us to the conclusion that it is most appropriate to correlate both the Zellia nunosei and Monodiexodina langsonsis zones with the Pseudoschwagerina (Robustoschwagerina) subsphaerica zone of Atetsu and the $P$. (s. s.) muongthensis zone of Akiyoshi. Regarding the basal member ( $\mathrm{Sa}$ ) of the formation we have no palaeontological evidence, but probably it may not extend in age as low as the basal part of the Triticites simplex zone of Akiyoshi and the Quasifusulina longissima ultima zone of Atetsu.

\section{B. Some remarks on the definition of the Sakamotozawa Series}

In the areas of calcareous sediments in Southwest Japan the lowest part of the Permian succession is represented by the Triticites simplex zone in the Akiyoshi and Taishaku areas, the Quasifusulina longissima ultima zone in the Atetsu, the Pseudoschwagerina morikawai zone in the Yayamadake, Kyushu and the Ichinotani, Hida Mountains. Except for that of the Ichinotani, these zones are delimited at their bases by a great stratigraphic hiatus indicated by wanting the whole part or the upper part of the Upper Carboniferous Triticites zone.

The base of the Sakamotozawa Formation is well marked by a distinct unconformity and directly overlies the Profusulinella zone. From a horizon immediately above the basal conglomerate a species of Pseudoschwagerina has been found (MinAto et al. 1954) as noted before. The zonal correlation mentioned in the foregoing chapter has led to the conclusion that the basal part ( $\mathrm{Sa}$ ) of the Sakamotozawa Formation does not probably extend down as low as the basal part of the Triticites simplex zone or the corresponding Pseudoschwagerina morikawai zone. Accordingly the lower limit of the Sakamotozawa Series, the biostratigraphic unit for the Lower Permian of Japan, cannot be palaeontologically defined by the base of the type Sakamotozawa Formation, but is taken at the base of the Triticites simplex zone or the corresponding Pseudoschwagerina morikawai zone of the reference sections in Southwest Japan.

As already mentioned, the uppermost part of the Sakamotozawa Formation is defined by the Pseudofusulina ambigua zone. The Kanokura Formation, which overlies the Sakamotozawa Formation probably with an unconformable relation (MinATo et al. 1964), is characterized by the common occurrence of Mondiexodina matsubaishi (FUJIMOTO) in its lower part (Fujimoto, 1956; OnUKI, 1956; Minato et al. 1959, 1964). While in Southwest Japan the $P$. ambigua zone and the corresponding $P$. kraffi magna zone are conformably overlain by the Parafusulina kaerimizensis zone or the corresponding Parafusulina sapperi zone, which are regarded as the typical main 
part of the so-called Zone of Parafusulina in Japan. In some other areas, i. e. the Kuma mountains in Kyushu, Akasaka in the Mino mountains, etc. the Neoschwagerina simplex zone takes place of the equivalent biostratigraphic unit (KANMERA, 1963).

As the fusuline faunas of the Kanokura Formation have not been studied adequately, it is still uncertain whether or not the Monodiexodina matsubaishi zone (Minato et al. 1964) is primarily correlated with the Parafuslina kaerimizensis zone and also the Neoschwagerina simplex zone. However from the order of their stratigraphic positions it is highly probable that the three zones under considerations are correlated with one another as one of us (K.K., 1963) has already suggested. Minato et al. (1964) expressed nearly the same opinion about this problem. It should be noted here that a remarkable faunal change is recognized between the $P$. ambigua zone and the Parafusulina kaerimizensis zone (ToRIYAMA, 1957). Thus from the stratigraphic sequences of the Sakamotozawa. Formation and the corresponding ones and on the species-assemblages of them it is most reasonable to define the upper limit of the Sakamotozawa Series at the top of the Pseudofusulina ambigua zone and the corresponding P. kraffti magna zone.

The zonal subdivisions of the Sakamotozawa Series are well defined on the basis of fossiliferous type sequence of the Sakamotozawa Formation and of the corresponding reference sections of Akiyoshi, Atetsu, Yayamadake etc. in Southwest Japan. What should be, however, noted here is that the fusuline faunas of the corresponding zones of the series show a fairly remarkable, local variation in the species-assemblage and the predominant species, as is shown by a differently named species of the zones. The difference is significant in the lower zones in particular. The reasons for this problem may be partly in the difference of facies, and partly in that of geographic province, but in detail there is much to be studied.

\section{Remarks on international correlation}

As the international scale of subdivisions of the Lower Permian strata on fusuline fossils the Pseudoschwagerina Zone below and the Parafusulina Zone above have been commonly used in many regions. However, taxonomic definition and assignment of the concerned schwagerinid genera have not always been agreed among authors. For instance there has been a serious controversy with regard to the taxonomic assignment of Pseudoschwagerina and Schwagerina (Dunbar and SkInner, 1936; Dunbar, 1958; RAUSer-Chernoussova, 1936; 1956), and in Russia the Pseudoschwagerina zone has been customarily called the "Schwagerina horizon". To cite another example, "Fusulina japonica GÜMBEL", a very common Lower Permian species in Japan, has been refered by some authors to Parafusulina on account of possessing cuniculi but by some others to Pseudofusulina in its rather short fusiform shape and thick spirotheca. Occasionally it has been also assigned to Schwagerina. This sort of disagreement in generic assignment is fouud not uncommonly within a country or among countries concerned. Some Japanese authors have brought into use the Pseudofusulina zone instead of the upper part of the Pseudoschwagerina zone or the lower part of the Parafusulina zone or the combined unit of these two parts.

Under these circumstances the generalization of the stratigraphic units in terms 
of the generic zone-names mentioned above may give confusion in the definition of the zones and may mislead international correlation. In fact the boundary between the zones is not always clearly defined and we often meet with discrepancy between authors in the definition and the stratigraphic range of the zones of the same name. In the present state of knowledge both Pseudoschwagerina and Parafusulina have a wide stratigraphic range. Therefore it is strongly desired that the zonal subdivisions. of every succession should be precisely defined by species zones with denotation of their lower and upper limits, and that a definite and workable provincial zonal scheme should be established before the generalization by generic zone-names.

On the basis of the zonal subdivision of the Sakamotozawa Series defined in the foregoing chapter, an approximate correlation of the series with representative sections. of some other provinces is attempted on this occasion.

The fusuline faunas of the Sakamotozawa Formation contain some closely allied species to those of the McCloud Limestone (THOMPson and WHEELER, 1949) of Shasta County, California. They are shown as follows, with the stratigraphic position of the fossil beds in brackets:

Parafusulina? turgida THOMPson and WHEELER: Pseudofusulina vulgaris vulgaris

(better referred to Pseudofusulina) $[\mathrm{Sc}]$

[ca 1100 feet above $P$. gracilis horizon)

Parafusulina? calx THOMPSON and WHEELER : Pseudofusulina sp. aff. P. japonica

(better referred to Pseudofusulina) [Sc]

[ca 1000 feet above $P$. gracilis horizon)

Parafusulina gracilis (MEEK)

(better transferred to Monodiexodina)

\section{: Monodiexodina langsonensis} $\left[\mathrm{Sb}_{2}\right]$

[at the base of the McCloud Limestone]

Of these, the second corresponding species may be possibly of subspecific distinction. Specially noteworthy here is the fact that the combined unit represented by the upper two species and the lowest fossil bed in the limestones under consideration are parallel in the order of the stratigraphic position. It is believed that the Monodiexodina langsonensis zone is correlated with the lower part of the McCloud Limestone and the Pseudofusulina vulgaris zone with the upper part of it. THOMPson and WHEELER have assigned the lower half of the McCloud to Wolfcampian and the upper part of it to Leonardian. An intimate connexion of the sea-ways between Japan and the West Coast region of North America is suggested in Lower Permian time as well as in Middle Permian time (Kanmera, 1963).

Ross $(1960 ; 1962 ; 1963 \mathrm{a}, \mathrm{b})$. published the results of his systematic studies of the fusuline faunas and the zonation of the Wolfcamp, Leonard and Word Formations of Glass Mountains, Texas, the type Permian sequence of North America. The correlation of the Sakamotozawa with these formations is a matter of difficulty, because none of the contained species are common to each other. However, the assemblages and the relative stratigraphic order of similar species suggest that the combined unit of the Zellia nunosei and Monodiexodina langsonensis zones (Member Sb) is correlated with the Lenox Hill Formation of Wolfcampian age and that of the Pseudofusulina vulgaris, 
$P$. fusiformis and $P$. ambigua zones (Members Sc and Sd) with Member $\mathrm{A}$ and the lower part of Member B of the Leonard Formation. Member C of the Leonard Formation contains large elongate species of Parafusulina which have well developed cuniculi. None of the Sakamotozawan species are comparable with those species in their shell-shape, shell-size and the degree of the septal fluting. The basal part (Sa) of the Sakamotozawa is hardly possible to range down to the age of the base of the lowest Wolfcampian Neal Ranch Formation, which contains, besides Pseudoschwagerina, Paraschwagerina and Schwagerina, several species of Triticites.

In the correlation chart of the Permian fusuline zones of selected areas of Japan, one of us (K. K., 1963) correlated the lower part of the Sakamotozawa Series with the lower half of the Chuanshan of South China and the upper part of it with the lower half of the Chihsian. His correlation is almost warranted by our present study and the new knowledge contributed by SHENG (1963) on the "Permian fusulinids of Kwangsi, Kueichow and Szechuan". The lower part of the newly defined Chihsia Limestone contains several common or closely allied species to those of the three zones of the Upper Sakamotozawa Formation (Member Sc and Sd). The identical species are Toriyamaia laxiseptata, Pseudofusulina fusiformis, $P$. kraffi and $P$. vulgaris, and the allied ones are Nagatoella parva, Pseudofusulina kueichowensis (s.s.) and P. kueichowensis obesa. The last species apparently belongs to a species-group of $P$. vulgaris. The upper part of the Chihsia Limestone has no common species to those of the Sakamotozawa, and the overlying Cancellina zone of the Maokou Limestone contains many large species of Parafusulina besides the index-species Cancellina primigena and C. neoschwagerinoides.

The zonation of the Chuanshan Limestone of South China has not yet been accomplished. For the correlation, therefore, we need more precise biostratigraphical data. According to CHEN (1934) and CHEN and SHENG (1957), however, the Chuanshan Limestone in characterized by many species of Triticites in its lower part, by the common occurrence of Quasifusulina longissima and Rugosofusulina alpina in its middle part and by the predominance of Pseudoschwagerina princeps in its upper part, although the last species is found from the bottom to the top of the limestone. From the stratigraphic order and on the assemblage of contained species the middle and upper parts of the Chuanshan are contemporaneous with the Monodiexodina langonensis zone including the Rugosofusulina alpina subzone in its middle part. The lower part of the Chuanshan may be correlated with the Triticites simplex zone or the corresponding Pseudoschwagerina morikawai zone, namely the basal part of the Sakamotozawa Series.

Comments must be given on this occasion about the Pseudoschwagerina zone of the Konkrin Formation ( $78.9 \mathrm{~m}$ in thickness) of the Kerigin area, Chekiang (CHANG, 1953a, b). Chang has divided the zone into three subzones, the Pseudoschwagerina paraspherica subzone $(18 \mathrm{~m})$, the Pseudofusulina valida subzone $(22.7 \mathrm{~m})$ and the Paraschwagerina inflata subzone $(38.2 \mathrm{~m})$. He correlated these three subzones with the upper half of the Chuanshan of South China. It is intersting to find, among the described species, Pseudoschwagerina schellwieni and Quasifusulina tenuissima from the same area, although their exact stratigraphic horizons have not been clearly shown. Schwagerina pailensis from the upper two subzones is closely allied to Monodiexodina 
langsonensis from the Lower Subformation of the Sakamotozawa Formation. Paraschwagerina dlakshanensis and the species referred to $P$. gigantea are also close to $P$. (Acervoschwagerina) sp. and $P .(P$.$) sp. A, respectively from the Monodiexodina lang-$ sonensis zone. Anyhow, it is highly probable that the upper two subzones of the Pseudoschwagerina zone of the Konkrin Formation correspond with the Monodiexodina langsonensis zone of the Sakamotozawa Series.

In China the boundary between the Carboniferous and the Permian is placed at the base of the Chihsia Limestone (Misellina zone by SHENG, 1963) in South China and at that of the Shanshi Limestone of North China. In other words the underlying Maping or Chuanshan and the Taiyuan Formation (the so-called Pseudoschwagerina zone) are regarded by Chinese geologists and palaeontogists as the Upper Carboniferous. The lower limit of the Permian of Japan has been placed by many authors at the base of the Sakamotozawa Series. In Russia RAuSER-CHERnoussova $(1958,1962)$ divided the Sakmarian of the type Permian section of the Southern Urals into the Asselian (Ruchenchev, 1954) below and the Sakmarian (s.s.) above. The former is correlated with the lower half of the Sakamotozawa Series and the latter with the upper half of it. Rauser-Chernoussova placed the lower limit of the Permian at the base of the Sakmarian (s.s.) from the viewpoints mainly of the phylogenetical development and the stratigraphical ranges of the schwagerinid genera. However, the Soviet-delegation (GoRsky and STEPANOV) at the 4 th Carboniferous Congress (1958) in Heerlen placed it at the base of the Sakmarian (s.l.) including the Asselian. We need more detailed consideration about the zonation and correlation and the physical changes of the concerned sequences of various regions before the solution of this disagreement.

\section{References}

Chen, S. (1934) : Fusulinidae of South China, Part 1. Palaeont. Sinica, [B], 4, (2), 1-133, pls. $1-16$.

CHANG, L.H. (1963): Upper Carboniferous Fusulinids from Kelpin and neighbouring areas, Hsin-Kiang (in Chinese and Russian). (I) Acta Palaeont. Sinica, 11; (1), 36-70, pls. 1-3 ; (II) Ibid., 11, (2), 200-227, pls. 4-9.

Chisaka, T. (1962): Fusulinids from the vicinity of Maiya town, Mitakami Mountainland, and Upper Permian fusulinids of Japan. Jour. Coll. Arts and Sci. Chiba Univ., [Nat. Sci.], 3, (4), 519-551, pls. 1-8.

Deprat, J. (1915) : Étude des Fusulinidés de Chine et d'Indochine et classification des calcaires a fusulines. IVe Mém. Les fusulinides des calcaires carbonifériens et Permiens du Tonkin, du Laos et du Nord-Annam. Mém. serv. géol. Indochine. 4, (1), 1-30, pls. 1-3.

Dunbar, C. O. (1933): Stratigraphic significance of the fusulinids of the Lower Productus Limestone of the Salt Range. Record of Geol. Survey India, 66, (4), 405-413, p1. 22. (1946): Parafusulina from the Permian of Alaska. Amer. Museum Novitates, 1325, 1-4, figs. 1-9.

Dunbar, C. O. and Skinner, J. W. (1937) : The geology of Texas. 3, (2), Permian Fusulinidae of Texas. Univ. Texas Bull., 3701, 517-742, pls. 42-81.

Dunbar, C. O. and Newell, N.D. (1946): Marine early Permian of the Central Andes and its fusuline faunas. Amer. Jour. Sci., 244, 377-402, 457-491, pls. 1-12.

Dyrenfurth, G. (1909) : Die Fusulinen von Darwas (Schellwien's Monographie der Fusulinen, Theil II), Palaeontogr., 56, 137-176, pls. 13-16.

Fujimoto, H. (Huzimoto, H.) (1936): Stratigraphical and palaeontological studies of the 
Titibu System of the Kwanto-Mountainland, Pt. 2, Palaeontology. Sci. Rep. Tokyo Bunrika Daigaku, [C], 1, (2), 29-125, pls. 1-26.

Fujimoto, H. and Kanuma, M. (1953): Minojapanella, a new genus of Permian fusulinids. Jour. Paleont., 27, (1), 150-152, pl. 19.

George, T.N. (1958): Lower Carboniferous palaeogeography of the British Isles. Proc. Yorkshire Geol. Soc., 31, (3), 227-318.

(1960) : Lower Carboniferous rocks in County Wexford. Quart. Jour. Geol. Soc. London, 116, 349-364, pls. 20-22.

HANZAWA, S. (1938): An aberrant type of the Fusulinidae from the Kitakami Mountainland, Northeastern Japan. Proc. Imp. Acad. Tokyo, 14, (7), 255-259, text-figs. 1-16.

(1938): Stratigraphical distributions of the genera Pseudoschwagerina and Paraschwagerina in Japan, with descriptions of two new species of Pseudoschwagerina from the Kitakami Mountainland, Northeastern Japan. Jap. Jour. Geol. Geogr., 16, (1-2), 65-73, p1. 4 .

- 1949$):$ A new type of the fusulinid foraminifera from central Japan. Jour. Paleont., 23, (2), 205-209, pl. 43.

HASEgAwA, Y. (1963): New find of fossils in the reddish tuffaceous shale in the Akiyoshi province. Earth Sci. (Chikyu Kagaku), 64, 32-37.

IGO, H. (1956): Notes on the Osobudani conglomerate and some Lower Permian fusulinids contained in its limestone pebbles, Part 1. Trans. Proc. Palaeont. Soc. Japan, N. S. 22, 169-174, pl. 27.

—_ (1959) : Some Permian fusulinids from the Hirayu district, Southern part of the Hida massif, central Japan. Sci. Rept. Tokyo Kyoiku Daigaku, [C], 6, (56), 231-254, pls. 1-4.

- (1964): On some Pseudoschwagerina and Zellia from Japan. Jour. Paleont., 38, (2), $281-293$, pls. 45,46 .

- (1957): Fusulinids of Fukuji, southeastern part of the Hida massif, central Japan. Sci. Rept. Tokyo Kyoiku Daigaku, [C], 5, 153-241, pls. 1-15.

KAHLER, F. and G. (1937): Beiträge zur Kenntnis der Fusuliniden der Ostalpen ; Die Pseudoschwagerinen der Grenzlandbänke und des oberen Schwagerinenkalks. Palaeontogr., [A], $87,1-43$, pls. $1-3$.

- and $(1940):$ Fusuliniden aus dem Tienschan. Neues Jahrb. für Mineral., Geol. u. Palaeont., Beil.-Bd. 83, [B], 348-362, pls. 9, 10.

- and $(1941)$ : Beiträge zur Kenntnis der Fusuliniden der Ostalpen: Die Gattung Pseudoschwagerina und ihre Vertreter im unteren Schwagerinenkalk und im Trogkofelkalk. Palaeontogr., 92, [A], 59-98, pls. 10, 11.

KAHLER, F. (1961) : Ungenauigkeiten der Karbon-Permgrenze im Bereich der Fusuliniden-Fazies. Neues Jahrb. Geol. Paläont., Monatsch. Jg. 1961, 3, 113-124.

Kanmera, K. (1956): Toriyamaia, a new Permian fusulinid genus from the Kuma massif, Kyushu, Japan. Trans. Proc. Palaeont. Soc. Japan, N.S., 24, 251-257, p1. 36.

- (1958): Fusulinids from the Yayamadake Limestone of the Hikawa Valley, Kumamoto Prefecture, Kyushu, Japan. Pt. III, Fusulinids of the Lower Permian. Mem. Fac. Sci., Kyushu Univ., [D], 6, (3), 153-215, pls. 24-35.

- (1962): Fusulines of the Middle Permian Kozaki Formation of Southern Kyushu. Ibid., 14, (2), 79-141, pls. 11-19.

Kanuma, M. (1959): Stratigraphical and paleontological studies of the southern part of the Hida Plateau and the northeastern part of the Mino Mountainland, central Japan. Pt. II, Paleontology. Bull. Tokyo Gakugei Univ., 10, 59-83, pls. 4-9.

KawANo, M. (1961) : Stratigraphical and paleontological studies of the Paleozoic formations in the western part of the Chugoku massif. Bull. Fac. Education, Yamaguchi Univ., Mathm. and Sci., 11, 1-133, pls. 1-15.

Kobayashi, M. (1957): Paleontological studies of the Ibukiyama Limestone, Shiga Prefecture, central Japan. Sci. Rep. Tokyo Kyoiku Daigaku, [C], 5, 247-311, pls. 1-10.

Kochansky-Devidé, V. (1959): Die Fusuliniden Foraminifera aus dem Karbon und Perm in Velebit und in der Lika (Kroatien). Unteres Perm. Palaeont. Jugoslavia, 3, 5-60, pls. 1-8. 
MAwson, D. (1929): Some South Australian algal limestones in process of formation. Quart. Jour. Geol. Soc., 85, (4), 613-623, pls. 35-41.

Minato, M. (1944) : Stratigraphische Gliederung des Perm des Süd-Kitakami-Gebirges, Japan (in Japanese with German abstract). Jour. Geol. Soc. Japan. 51, (606), 83-90.

Minato, M., Hashimoto, S., Suyama, K., TAkeda, Y., Suzuki, Y., Kakimi, T., Yamada, K., Kimura, S., Ichikawa, T., und Suetomi, H. (1954) : Zur Biostratigraphie der permischen Formation des Setamai-Geländes im Süd-Kitakami Gebirge. (in Japanese with German abstract). Ibid., 60, (708), 378-387.

Minato, M., Takeda, H., Suetomi, H., and Kato, M. (1959): On the volcanic rocks in the Japanese Paleozoic, 3rd Rept.-Permian (in Japanese with English abstract). Ibid., 65, (763), 222-226.

Minato, M., Kato, M. and Hasegawa, Y. (1964): A note on the boundary batween Pseudofusulina anc Parafusuliha zones in Japan. Proc. Japan Acad. 40, (10), 827-831.

Morikawa, R. (1953) : Fusulinids from the Kitakami Mountainland (in Japanese with English abstract). Ibid., 59, (691), 149-159.

pl. 1.

(1952): On a new genus Fujimotoella. Ibid., 35-37, p1. 1.

(1955): Schwagerininae in the vicinity of the Shomaru pass, eastern part of Kwanto. Mountainland, central Japan. Ibid., [B], 2, (1), 45-114, pls. 5-15.

_._. (1958): Fusulinids from the Akasaka Limestone, Part 1. Ibid., 3, (1), 93-127, pls. 12-26. MorikawA, R. and Isomi, H. (1961): Studies of Permian fusulinids in the east of Lake Biwa, central Japan. Geol. Survey of Japan, Rept., 191, 1-29, pls. 1-21.

Murata, M. (1964): Geological age of the Kanokura Formation in the Southern part of the. Kitakami massif, Northeast Japan. Saito Ho-on Kai Museum Research Bull., 33, 17-29.

Nogami, Y. (1961): Permische Fusuliniden aus dem Atetsu-Plateau Sud-Westjapans. Teil 1, Fusulininae und Schwagerininae. Mem. Coll. Sci., Univ. Kyoto, [B], 27, (3), 159-225, pls. 1-11.

OzAwA, Y. (1925): Paleontological and stratigraphical studies on the Permo-Carboniferous Limestone of Nagato. Part III, Paleontology. Jour. Coll. Sci., Imp. Univ. Tokyo, 45, (6), 1-90, pls. 1-14.

(1927) : Stratigraphical studies of the Fusulina Limestone of Akasaka, Province of Mino. Jour. Fac. Sci., Imp. Univ. Tokyo, [II], 3, 121-164, pls. 34-45.

(1923): On some species of Fusulina from Honan, China. Jap. Jour. Geol. Geogr., 2, (2), 35-39, pl. 5 .

ONuki, Y. (1956): Geology of the Kitakami massif. Explanatory text of the geological map of Iwate Prefecture. 1-189.

Onuki, Y., Murata, M., Bando, Y. and Mito, A. (1960): On the Permian System of the Maiya district in the southern Kitakami Massif, Japan. Jour. Geol. Soc. Japan. 66, (782), 717-732.

Ross, C. A. (1960) : Fusulinids from the Hess Member of the Leonard Formation, Leonard Series (Permian), Glass Mountains, Texas. Contr. Cushman Found. Foramin. Research, 11 , (4), 117-133, pls. 17-21.

(1962): Fusulinids from the Leonard Formation (Permian), Western Glass Mountains, Texas. Ibid., 13, (1), 1-21, pls. 1-6.

- (1962): The evolution and dispersal of the Permian fusulinid genera Pseudoschwagerina. and Paraschwagerina. Evolutions, 16, (3), 306-315.

(1963): Fusulinid from the Word Formation (Permian), Glass Mountains, Texas. Contr. Cushman Found. Foramin. Research, 14, (1), 17-31, pls. 3-5.

(1963): Standard Wolfcampian Series (Permian), Glass Mountains, Texas. Geol. Soc. Amer., Mem. 88, 1-168, pls. 2-29.

Rauser-Chernoussova, D. M. (1437): Rugosofusulina, a new genus of fusulinids. Moscou Univ., Studies in Micropaleont. 1, (1), 21-25, pls. 1-3.

(1962) : Der Schwagerinen-Horizont und die obere Grenze des Karbon. Compte Rendu, Quatr. Congr. Stratig. Géol. du Carbon. Heelen, III, 577-589.

SUYARI, K. (1962): Geological and paleontological studies in central and eastern Shikoku, 
Japan. Pt. II, Paleontology. Jour. Gakugei, Tokushima Univ., Nat. Sci., 12, 1-59, pls. 1-12. SAKAGAMI, S. (1958) : Fusulinids from the Upper Permian conglomerates of Northern part of Itsukaichi, Tokyo-to, Japan. Jour. Hokkaido Gakugei Univ., 9, (2), 72-97, pls. 1-4.

SAURIN, E. (1950) : Les Fusulinides des calcaires des Ky-Lua, Langson (Tonkin). Bull. service géol. Indochine, 29, (5), 6-32, pls. 1-7.

- (1954): Notes paleontologiques sur quelques calcaires a Fusulinides du Nord Viet-Nam.

1. Les calcaires de Campha Mines. Recherches Scientifiq. et. Techniq. Archives geol. du Viet-Nam. 1, 3-21, pls. 1-3.

Sabins, F.F. Jr. and Ross, C.A. (1963) : Late Pennsylvanian-Early Permian Fusulinids from Southeast Arizona. Jour. Paleont. 37, (2), 323-365, pls. 35-40.

SCHWAGER, C. (1883) : Carbonische Foraminiferen aus China und Japan. in Richtofen's China, 4, 106-159, pls. $15-18$.

(1887) : Salt Range fossils, Subkingdom Protozoa. Paleont. Indica, 1, (4), 983-994, pls. $126-128$.

Schellwien, E. (1.898) : Die Fauna des karnischen Fusulinenkalks. Theil II : Foraminifera. Palaeontogr., 44, 237-282, pls. 17-24.

(1908): Monographie der Fusulininen. Teil I : Die Fusulinen, der russisch-arktischen Meeresgebiets. Ibid., 55, 145-194, pls. 13-20.

Schellwien, E. and Dyhrenfurth, G. (1909) : Monographie der Fusulinen. Theil II : Fusulinen von Darwas. Ibid., 137-176, pls. 13-16.

Sheng, J. C. (1963) : Permian fusulinids of Kwangsi, Kueichou Szechuan. Paleont. Sinica, N.S. $10,1-115,129-247$, pls. 1-36.

Stewart, W. J. (1963) : The fusulinid genus Chusenella and several new species. Jour. Paleont., 37, (6), 1150-1163, pls. 155-158.

Thompson, M.L. (1948): Studies of American Fusulinids. Univ. Kansas Paleont. Contr., Protozoa, 1, 1-102, pls. 1-38.

(1954): American Wolfcampian fusulinids. Ibid., 5, 1-226, pls. 1-52.

(1964): Fusulinacea, in Treatise on Invertebrate Paleontology. (Ed. R. C. Moore), Pt. C, Protista 2, C358-436.

Thompson, M. L., Wheeler, H. E. and Hazzard, J. C. (1946) : Permian Fusulinids of California. Geol. Soc. Amer., Mem., 17, 1-53, pls. 1-18.

Toriy ama, R. (1952) : Permian fusulinids from the Kitakami Mountainland, Northeast Japan. Mem. Fac. Sci., Kyushu Univ., [D], 3, (3), 127-256, pls. 3-7.

(1957): Geology of Akiyoshi, Scientific Report on Akiyoshi-dai, Board of Education, Yamaguchi Pref: 1-36.

(1958) : Geology of Akiyoshi. Pt. III, Fusulinids of Akiyoshi, Mem. Fac. Sci., Kyushu Univ., [D], 7, 1-264, pls. 1-48.

White, M.P. (1932) : Some Texas Fusulinidae. Univ. Texas Bull., 3211, 5-85, pls. 1-10. 
Table 1. Distribution of the Fusulinacean species in the Sakamotozawa Formation of the Sakamotozawa-Nagaiwa area.

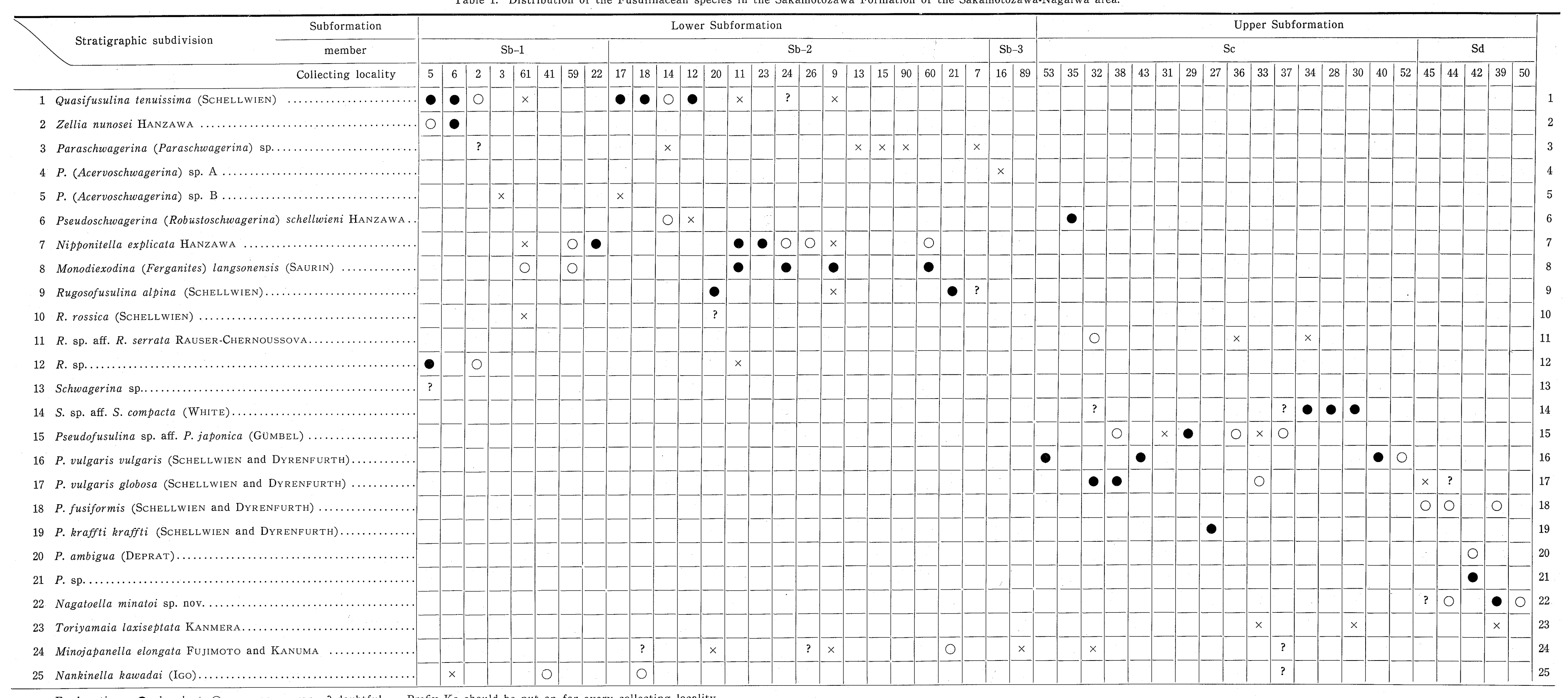

Explanation : 
Kametoshi KANMERA and Takahiko MIKAMI

Fusuline Zonation of the Lower Permian Sakamotozawa Series

Plates $44-53$ 
Plate 44 


\section{Explanation of Plate 44}

All figures are $\times 10$

Figs. 1-5. Quasifusulina tenuissima (SCHELLwIEN)

1, Axial section, compressed towards the direction perpendicular to the paper, GK.D 12694 from loc. Ks 14; 2, axial section of a typical form, GK. D 12562 from loc. Ks $14 ; 3$, axial section of a slightly compressed specimen, GK. D 12663 from loc. Ks 9 ; 4. axial section of a highly deformed specimen, GK. D 12558 from loc. Ks 18 ; 5, sagittal section, GK. D 12704 from loc. Ks 17.

Fig. 6. Rugosofusulina sp.

Axial section, GK. D 12606 from loc. Ks 2 .

Fig. 7. Pseudofusulina kraffti kraffti (SCHELlwien and DyrenfurTh) 300 Axial section, GK.D 12584a from loc. Ks 27.

Figs: 8-10. Pseudofusulina ambigua (DEPRAT)

8, Axial section, slightly compressed, GK. D 12556; 9, axial section, GK. D 12551a: 10, tangential section, GK. D 12551b. All from loc. Ks 42 . 

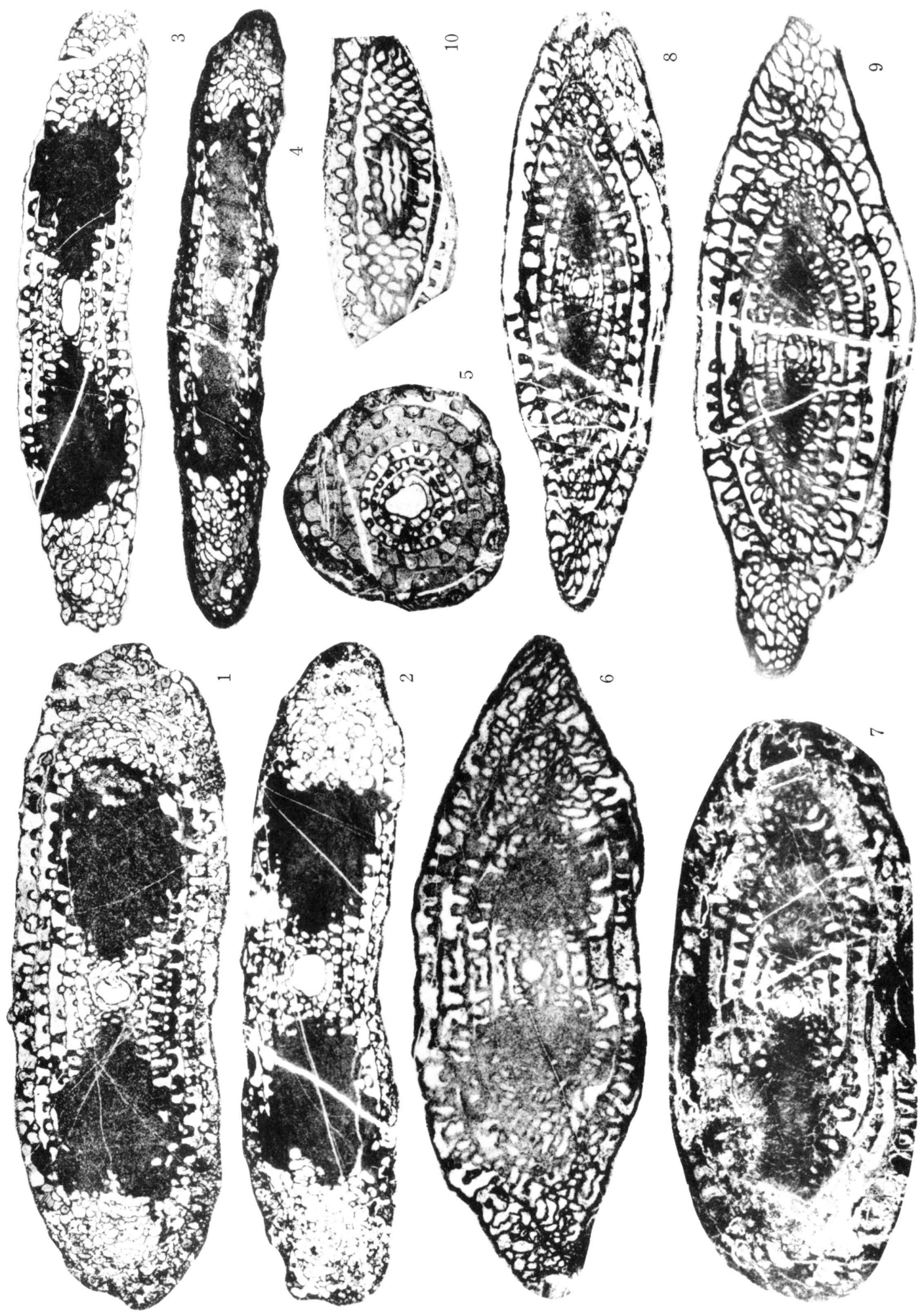
Plate 45 


\section{Explanation of Plate 45}

All figures are $\times 10$

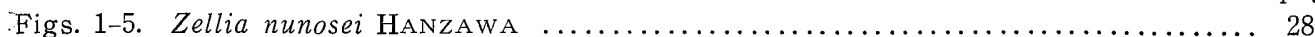

1, Slightly diagonal axial section, GK. D 12502; 2, slightly deformed axial section, GK.D 12503; 3, slightly diagonal axial section, GK. D 12512 ; 4, sagittal section, GK. D 12506 ; 5, slightly deformed sagittal section, GK. D 12505 . All from loc. Ks 6 .

Figs. 6-9. Pseudofusulina sp. (see also Plate 50)

6, 7, Axial sections, slightly compressed, GK. D 12571 and 12572 , respectively; 8 , incomplete axial section, GK. D 1255 ; 9, slightly diagonal axial section. GK. D 12577. All from loc. Ks 42 .

Fig. 10. Minojapanella elongata Fujimoto and KANUAMA ...

Slightly diagonal axial section, GK.D 12622 from loc. Ks 9. 

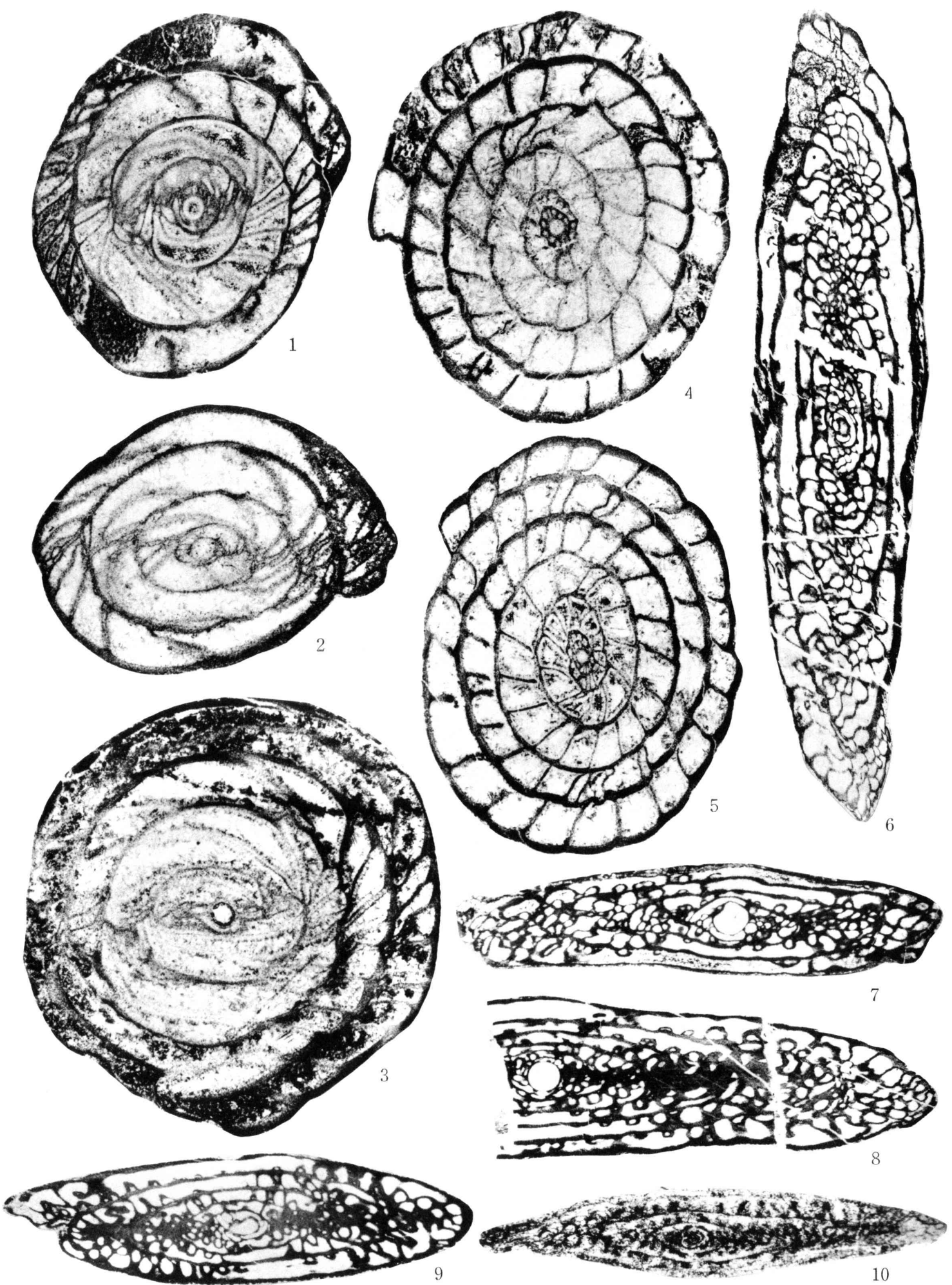
Plate 46 


\section{Explanation of Plate 46}

Fig. 1. Paraschwagerina (Acervoschwagerina) sp. A (see also Plates 47 and 49 ) ............. Parallel section, GK. D 12697 from loc. Ks $16 . \times 8$

Figs. 2-5. Pseudoschwagerina (Robustoschwagerina) schellwieni HANZAwA ............ 2, Slightly diagonal axial section, GK. D 12692a; 3, slightly diagonal sagittal section, GK. D 12695a; 4, tangential section crossing the outer part of a juvenarium, GK. D 12518 ; 5, tangential section, GK. D 12519.

2,3 and 4 from loc. Ks $14 ; 5$ from loc. Ks 12 . All $\times 8$

Figs. 6-8. Nankinella kawadai (IGo)

6. Incomplete tangential section, GK.D 12618; 7, axial section, GK.D 12504; 8, tangential section crossing juvenarium, GK. D 12619.

6 and 8 from loc. Ks $18 ; 7$ from loc. Ks 6 . All $\times 20$

Figs. 9, 10. Toriyamaia laxiseptata KANMERA

9, Oblique section, GK. D 12604 from loc. Ks $30 ; 10$, tangential section crossing a juvenile part, GK.D 12624 from loc. Ks 33 . All $\times 20$ 


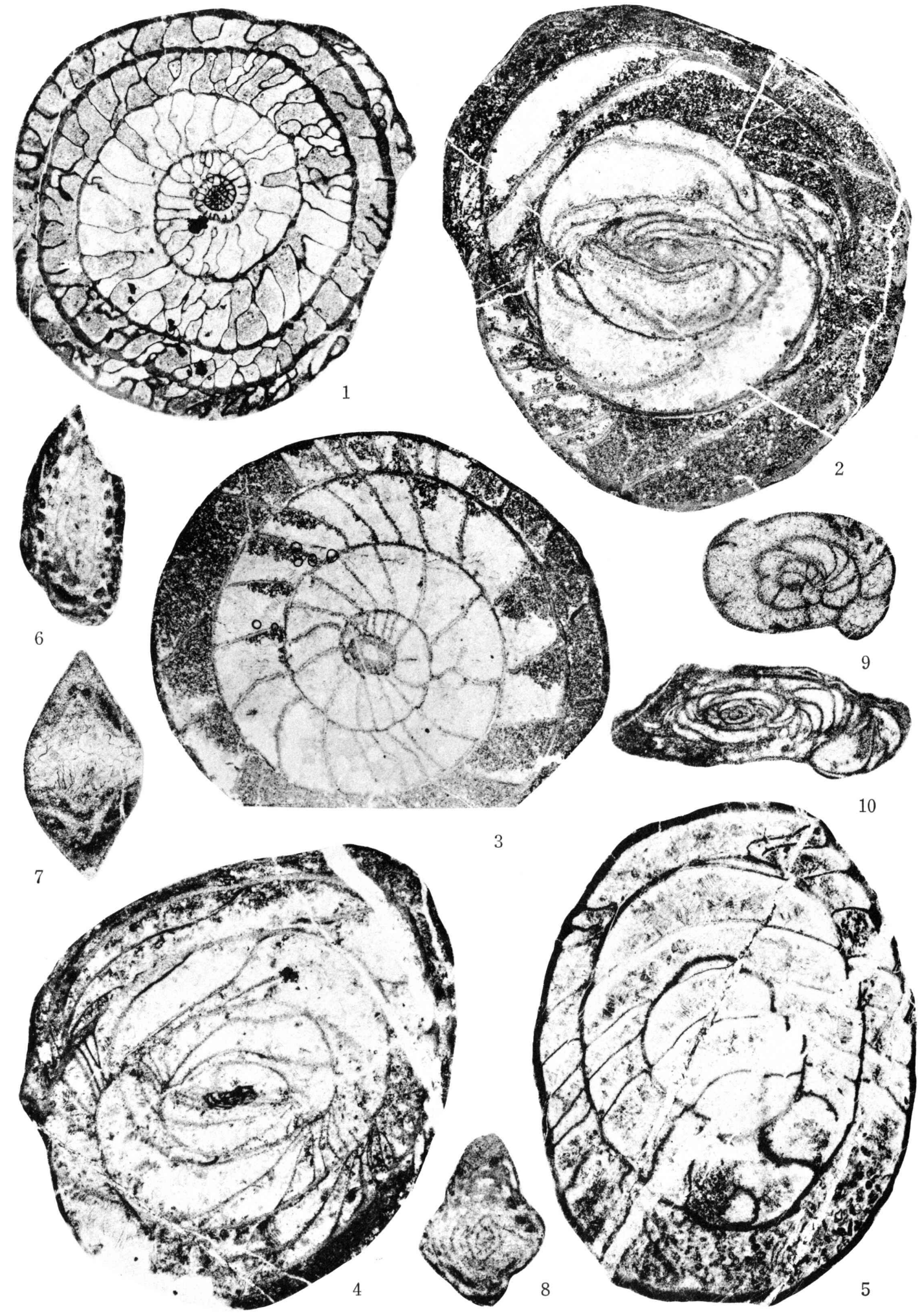

Kanmera and Mikami: The Sakamotozawan fusulinaceans 
Plate 47 


\section{Explanation of Plate 47}

All figures are $\times 8$

Figs. 1-3. Paraschwagerina (Paraschwagerina) sp.

1, Slightly diagonal axial section, GK. D 12520 from loc. Ks 13 ; 2, tangential section crossing the outer part of a juvenarium, GK. D 12523 from loc. Ks 7 ; 3, tangential section, GK. D 12522 from Ks 15.

Figs. 4, 5. Paraschwagerina (Acervoschwagerina) sp. A (see also Plates 46 and 49) ... 286 4, tangential section, GK. D 12524 ; 5, sagittal section, GK. D 12698 . All from loc. Ks 16. 


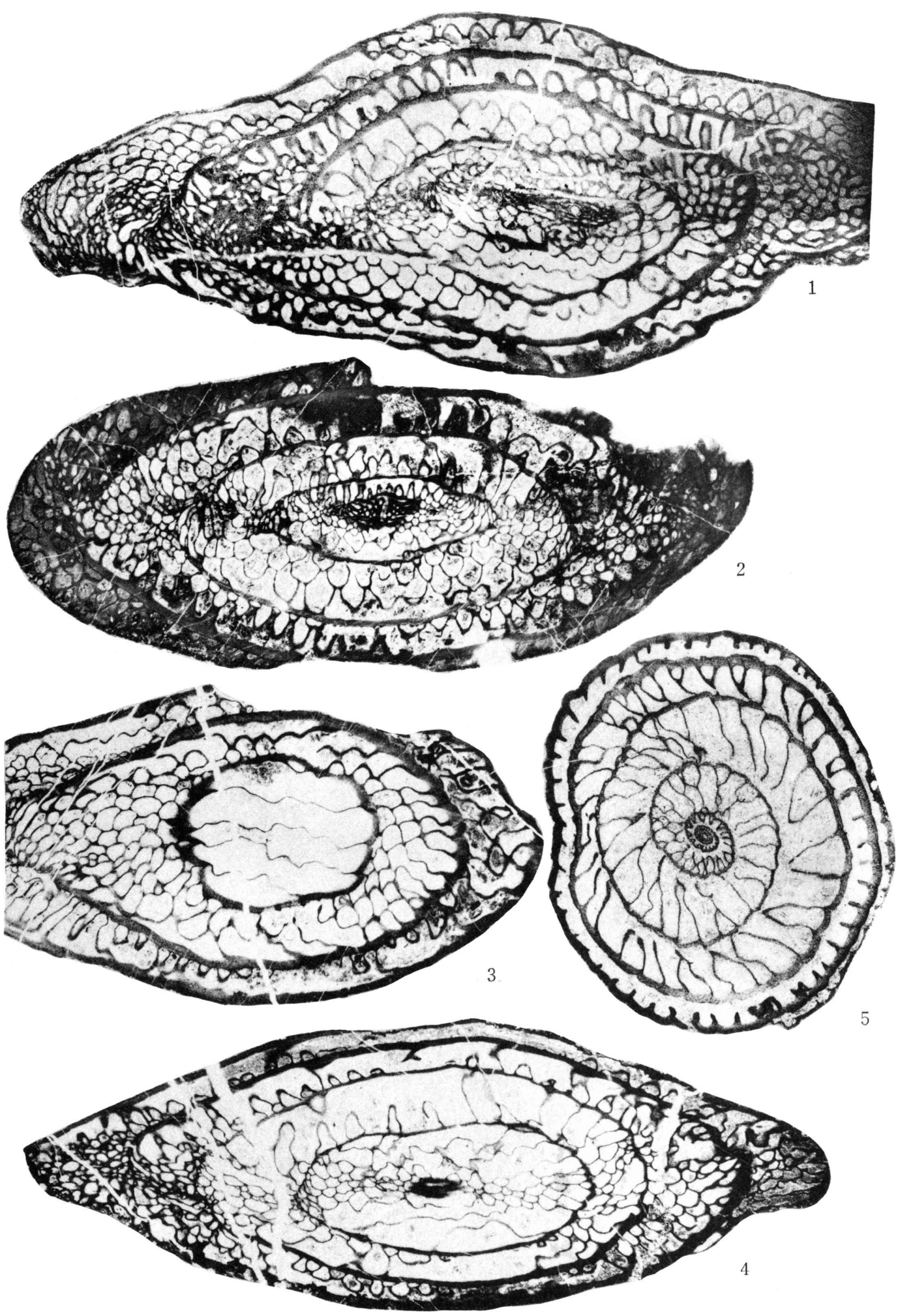

Kanmera and Mikami; The Sakamotozawan fusulinaceans 
Plate 48 


\section{Explanation of Plate 48}

All figures are $\times 10$, except for Fig. 16

Figs. 1-11. Monodiexodina (Ferganites) langsonensis (SAURIN)

1, Axial section, GK. D 12658a; 2, axial section (the largest one among the obtained specimens), GK. D $12640 ; 3-8$, axial sections $(3 ; 6,7$, slightly compressed ; 4, slightly deformed obliquely), GK.D 12667, 12641, 12666, 12647, 12644 and 12673a, respectively; 9, sagittal section, GK. D 12642b ; 10, 11, tangential sections, GK. D 12661b and 12656, respectively.

$1,2,7,10$ and 11 from loc. Ks $9 ; 3$ and 5 from loc. Ks $61 ; 4$ and 9 from loc. Ks $24 ; 6$ and 8 from loc. Ks 11 .

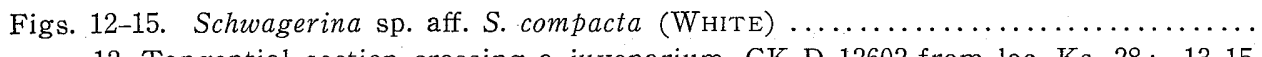
12, Tangential section crossing a juvenarium, GK. D 12602 from loc. Ks. 28; 13-15, axial sections, GK.D 12601a, 12598a and 12601b, rescpectively, from loc. Ks 34 .

Fig. 16. Minojapanella elongata Fujimoto and Kanuma (see also Plate 45)........... Tangential section of a deformed specimen, GK. D 12605b from loc. Ks $32 . \times 25$ 

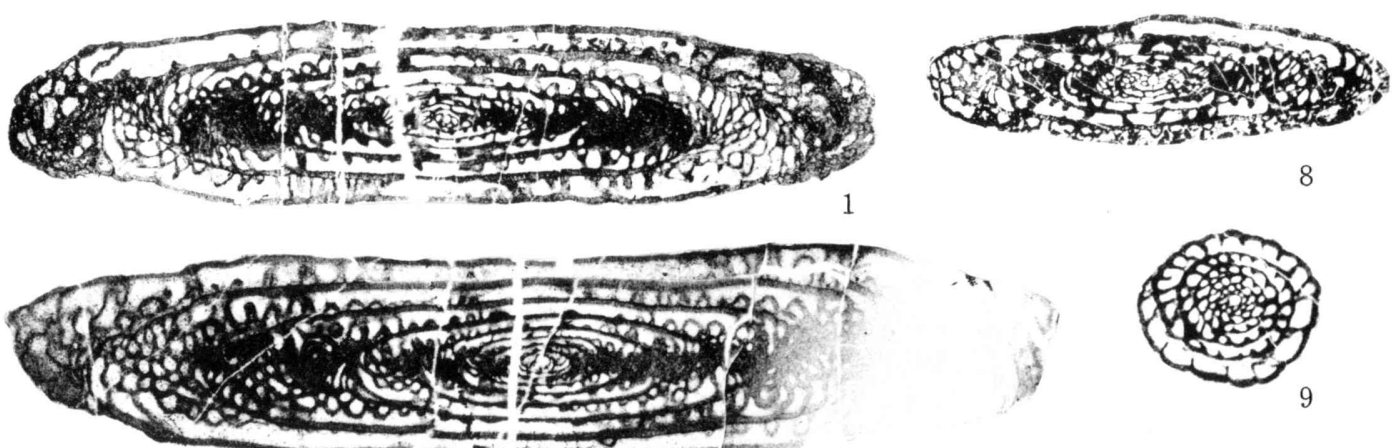

8
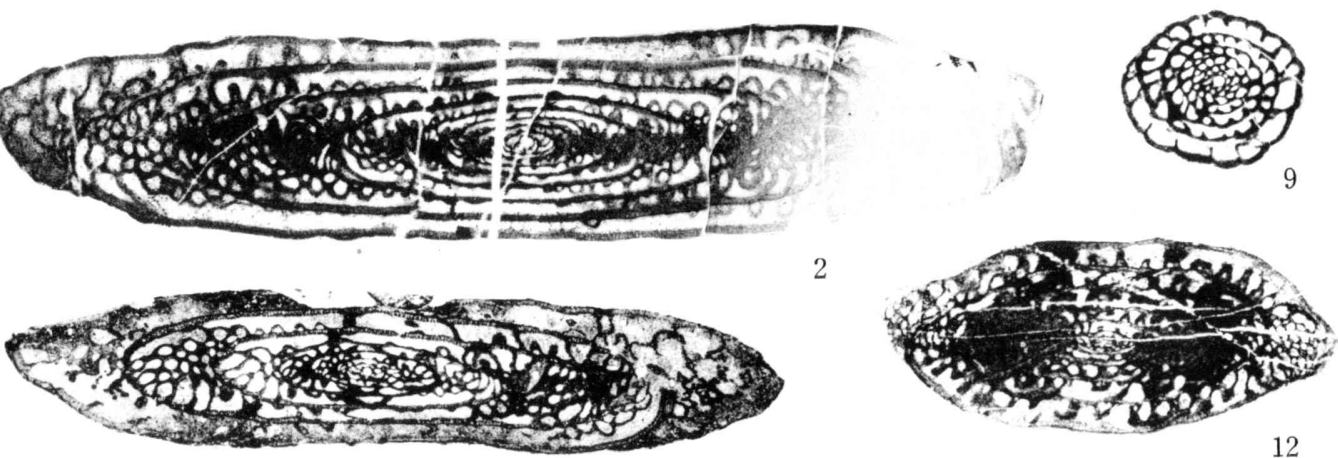

3
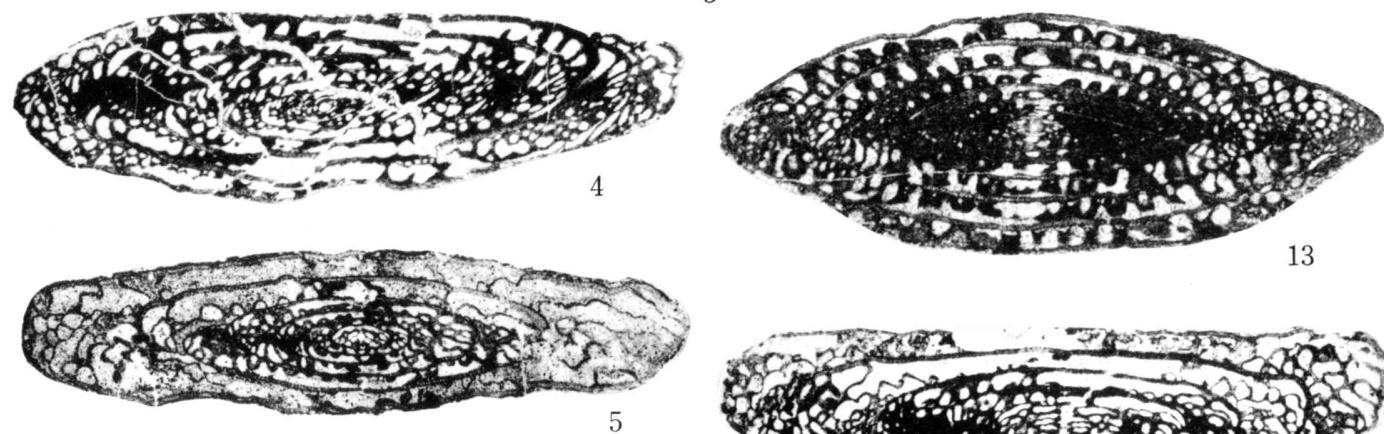

13

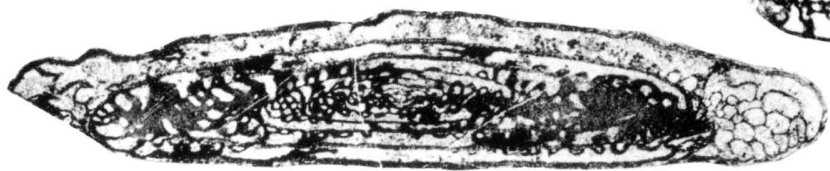

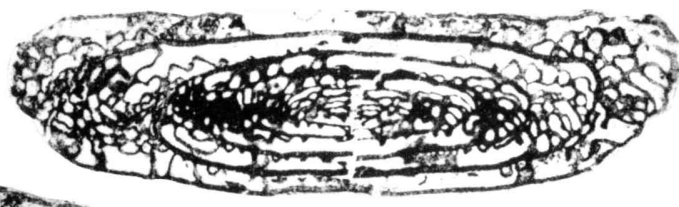

6

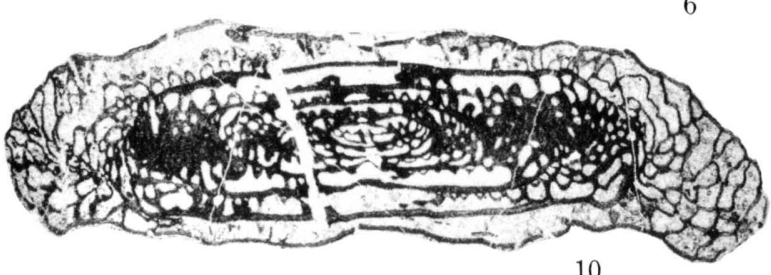

10
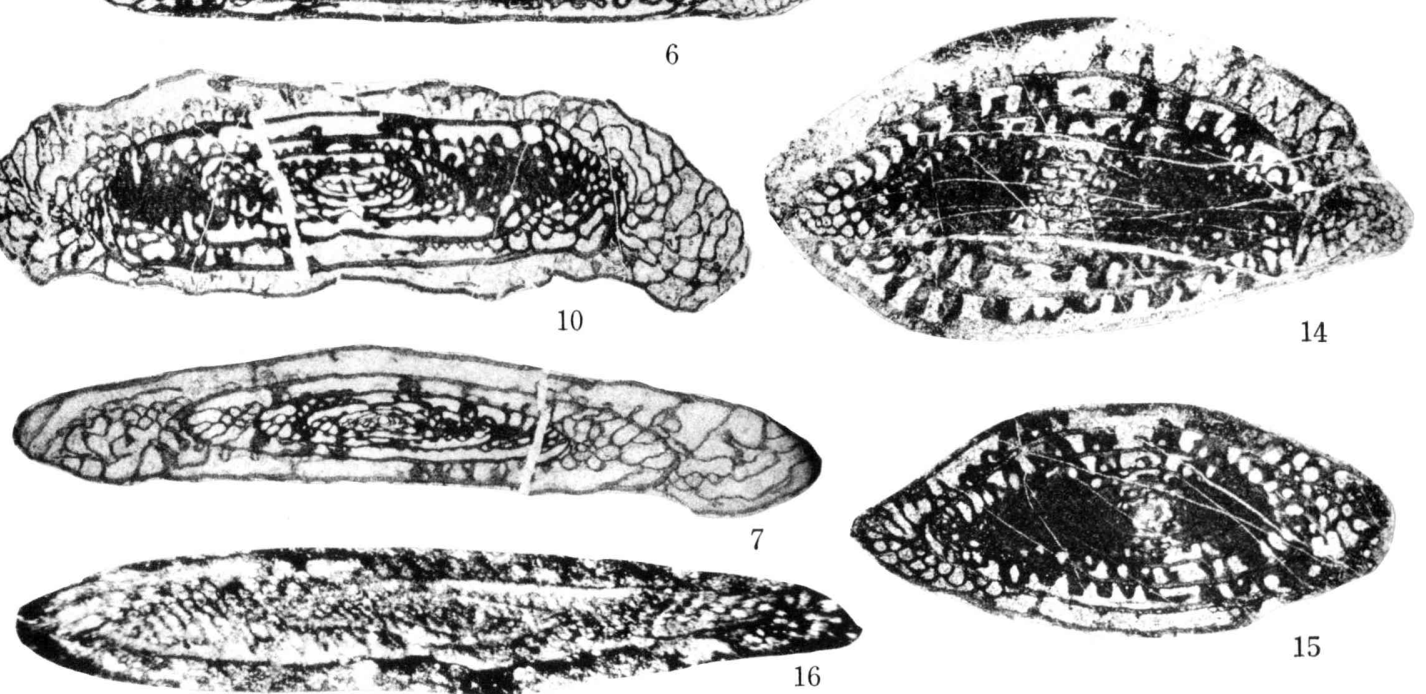
Plate 49 


\section{Explanation of Plate 49}

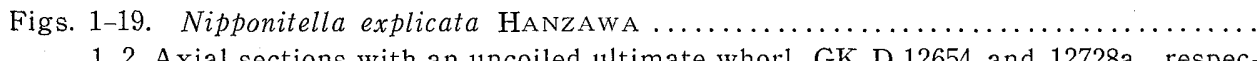

1, 2, Axial sections with an uncoiled ultimate whorl, GK. D 12654 and $12728 \mathrm{a}$, respectively; 3, 4, 5, axial sections of coiled parts of shells, GK.D 12728b, 12724 and 12686a, respectively; 6-11, tangential sections, GK. D 12681a, 12686b, 12653a, 12687c, 12685 and $12673 \mathrm{~b}$, respectively; 12, parallel section, GK.D 12650; 13-17, sagittal sections, GK.D 12687a, 12726a, 12721, 12722a and 12687b, respectively. 18, slightly diagonal sagittal section, GK.D 12723b; 19, sagittal section, GK. D 12658b.

$1,6,8$ and 11 are from loc. Ks $11 ; 2,3,4,9$ and $13-18$ from loc. Ks $22 ; 5,7$ and 10 are from loc. Ks $59 ; 12$ from loc. Ks $24 ; 19$ from loc. Ks 9 . All $\times 10$

Fig. 20. Paraschwagerina (Acervoschwagerina) sp. A (see also Plates 46 and 47 ) ..... 286 Diagonal section, GK.D 12702 from loc. Ks $16 . \times 5$ 

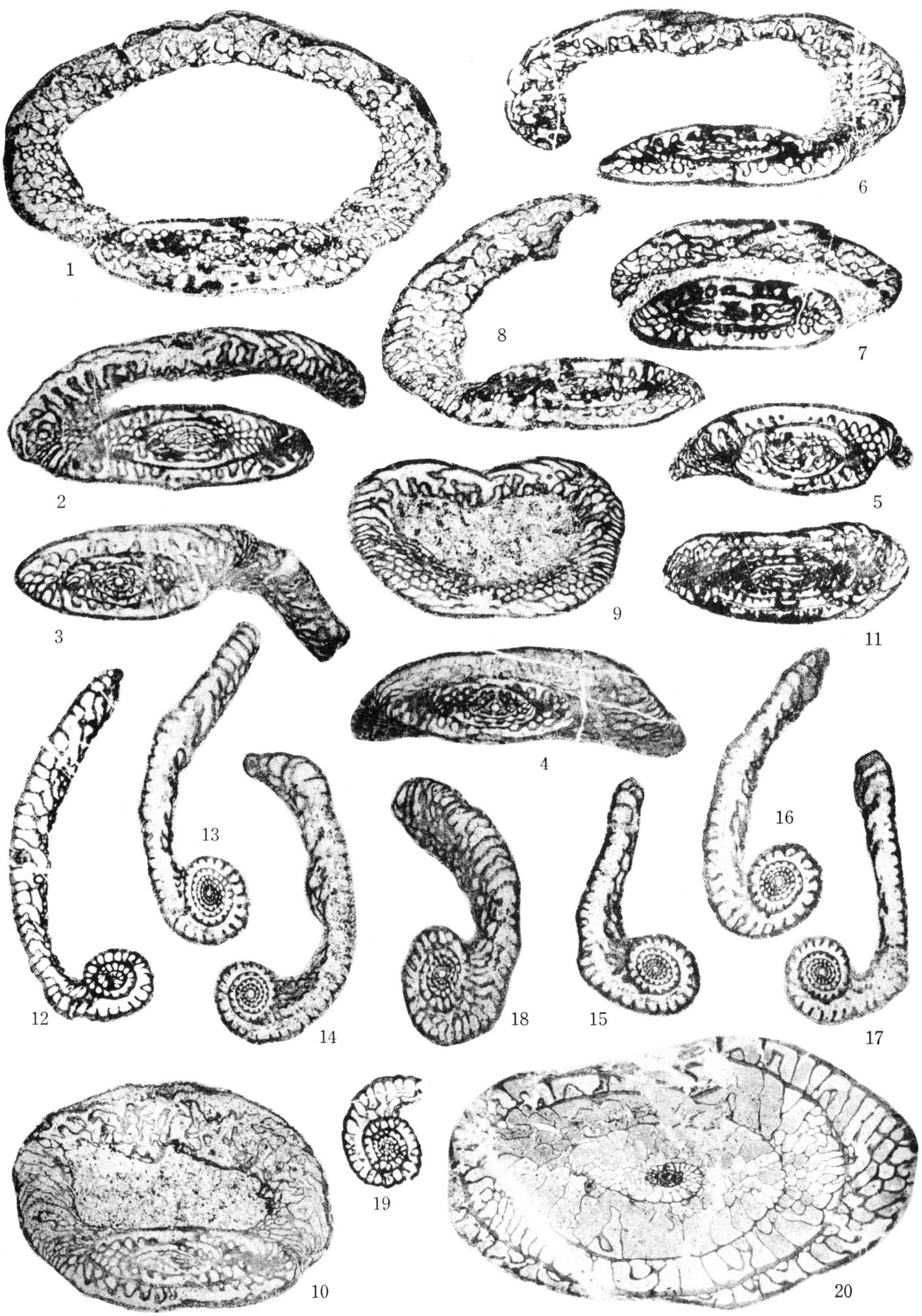

Kanmera and Mikami: The Sakamotozawan fusulinaceans 
Plate 50 


\section{Explanation of Plate 50}

All figures are $\times 10$

Figs. 1-5. Rugosofusulina alpina (Schellwien)

1, Axial section, GK. D 12563a; 2, 3, incomplete axial sections, GK. D 12565 and 12564, respectively; 4, tangential section of an immature specimen, GK.D 12662 ; 5 , axial section of an immature specimen, GK. D 12661a.

1,2 and 3 are from loc. Ks $21 ; 4$ and 5 from loc. Ks 9 .

Fig. 6. Rugosofusulina rossica (SCHELLwien) 292

Axial section, GK. D 12668 from loc. Ks 61.

Fig. 7. ? Rugosofusulina rossica (SCHELlWIEN) 292 Axial section, GK. D 12569 from loc. Ks 20.

Fig. 8. Pseudofusulina sp. (see also Plate 45) 304 Sagittal section, slightly deformed, GK.D 12575 from loc. Ks 42.

Figs. 9-11. Nagatoella minatoi sp. nov. (see also Plate 53). 307

9, Tangential section of a paratype, GK. D 12714b; 10,11, parallel sections of paratypes, GK. D $12713 \mathrm{~b}$ and $12717 \mathrm{~b}$, respectively. All from loc. Ks 39. 

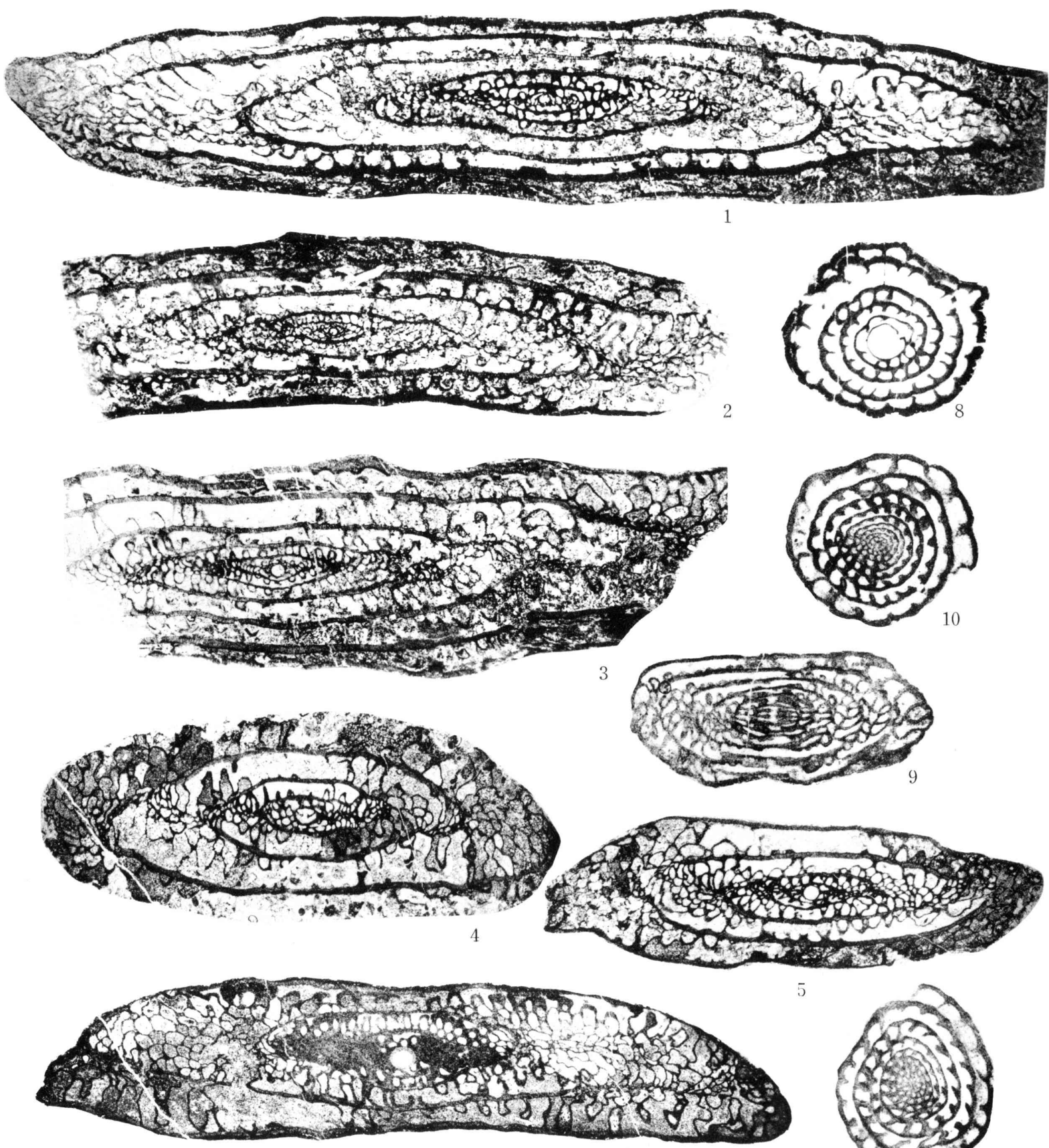

6

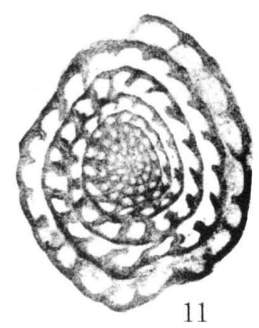

11

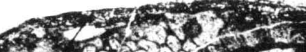

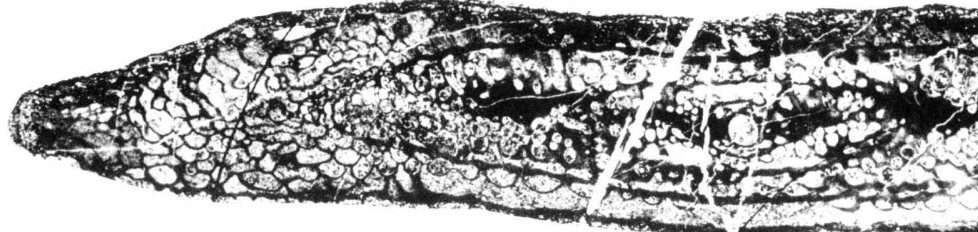


Plate 51 


\section{Explanation of Plate 51}

All figures are $\times 8$

Figs. 1-3. Pseudofusulina vulgaris vulgaris (SCHELLwien) $\ldots \ldots \ldots \ldots \ldots \ldots \ldots \ldots \ldots$ Axial sections, GK. D 12530, 12528 and 12529, respectively, from loc. Ks 43.

Figs. 4-9. Pseudofusulina vulgaris globosa (SCHELlwiEN) 4-8, Axial sections, GK. D 12630a, 12628, 12626 and 12543, respectively; 9, sagittal section, GK.D $12629 ; 4,5,6$ and 9 are from loc. Ks. 38 ; 7 from loc. Ks 33 ; 8 from loc. Ks 45 .

Figs. 10-12. Paraschwagerina (Acervoschwagerina) sp. B. 10, Incomplete tangential section crossing a juvenarium, GK. D 12703; 11, parallel section, GK. D 12706. 12, incomplete axial section, GK. D 12707. All from loc. Ks 17. 


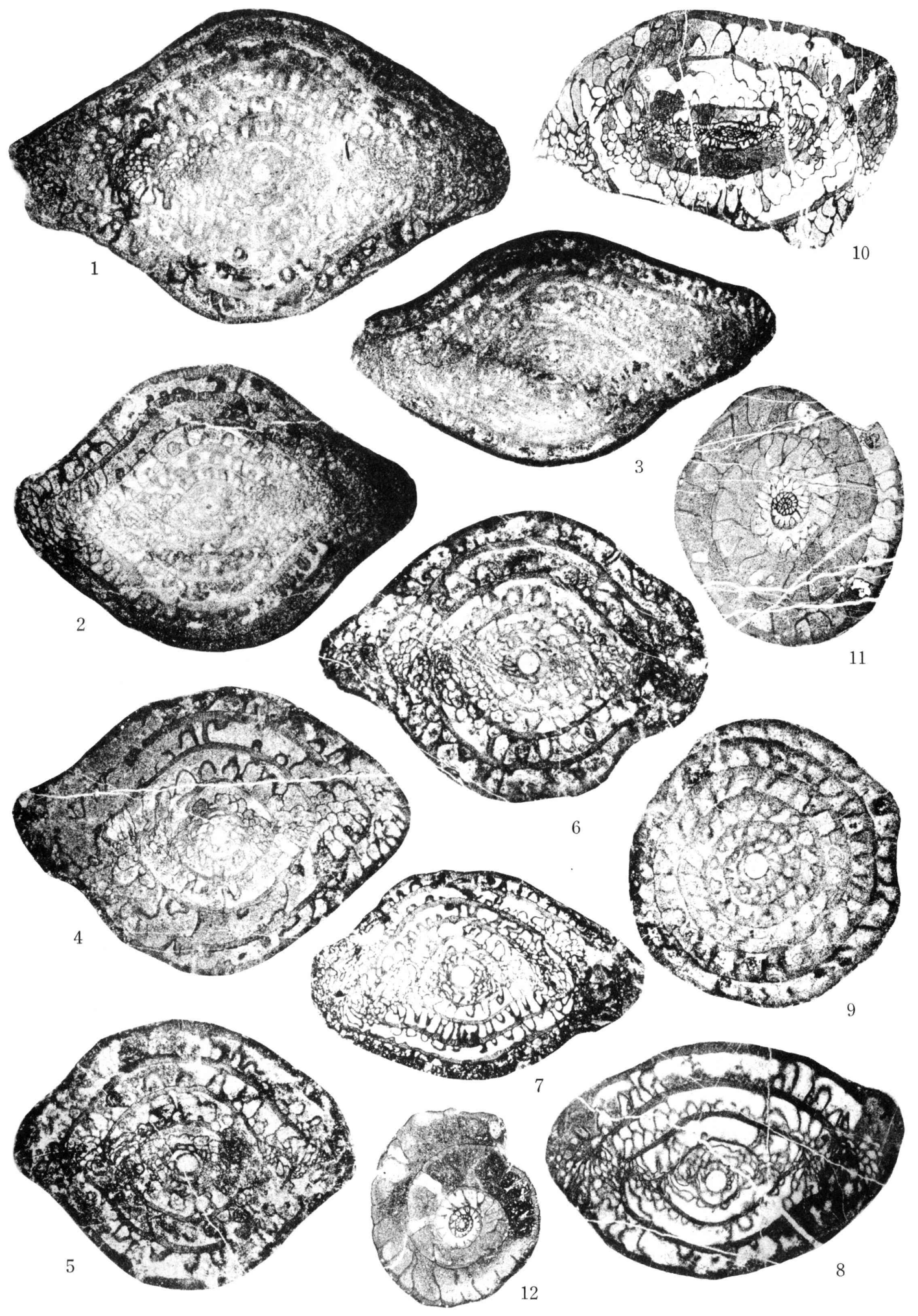

Kanmera and Mikami: The Sakamotozawan fusulinaceans 
Plate 52 


\section{Explanation of Plate 52}

All figures are $\times 10$

Figs. 1-6. Pseudofusulina fusiformis (SCHELLWIEN)

1, 2, Axial sections, GK.D 12579 and 12580, respectively; 3, 4, slightly diagonal axial sections, GK. D 12712a and 12583 , respectively; 5, 6, sagittal sections, GK. D $12712 \mathrm{~b}$ and $12714 \mathrm{c}$, respectively. 1 and 2 are from loc. Ks $44 ; 3,5$ and 6 from loc. $\mathrm{Ks} 39 ; 4$ from loc. Ks 45 .

Fig. 7. Schwagerina sp.

Slightly deformed axial section, GK. D 12459 from loc. Ks 18.

Figs. 8-11. Rugosofusulina sp. aff. R. serrata RAUSER-CHERnoussova ...............
8, Axial section, GK. D $12637 ; 9$, slightly deformed axial section, GK. D $12605 ; 10$, incomplete axial section, slightly deformed, GK. D $12591 ; 11$, axial section, GK. D 12636.

8 and 9 are from loc. Ks $32 ; 10$ and 11 from loc. Ks 36 . 

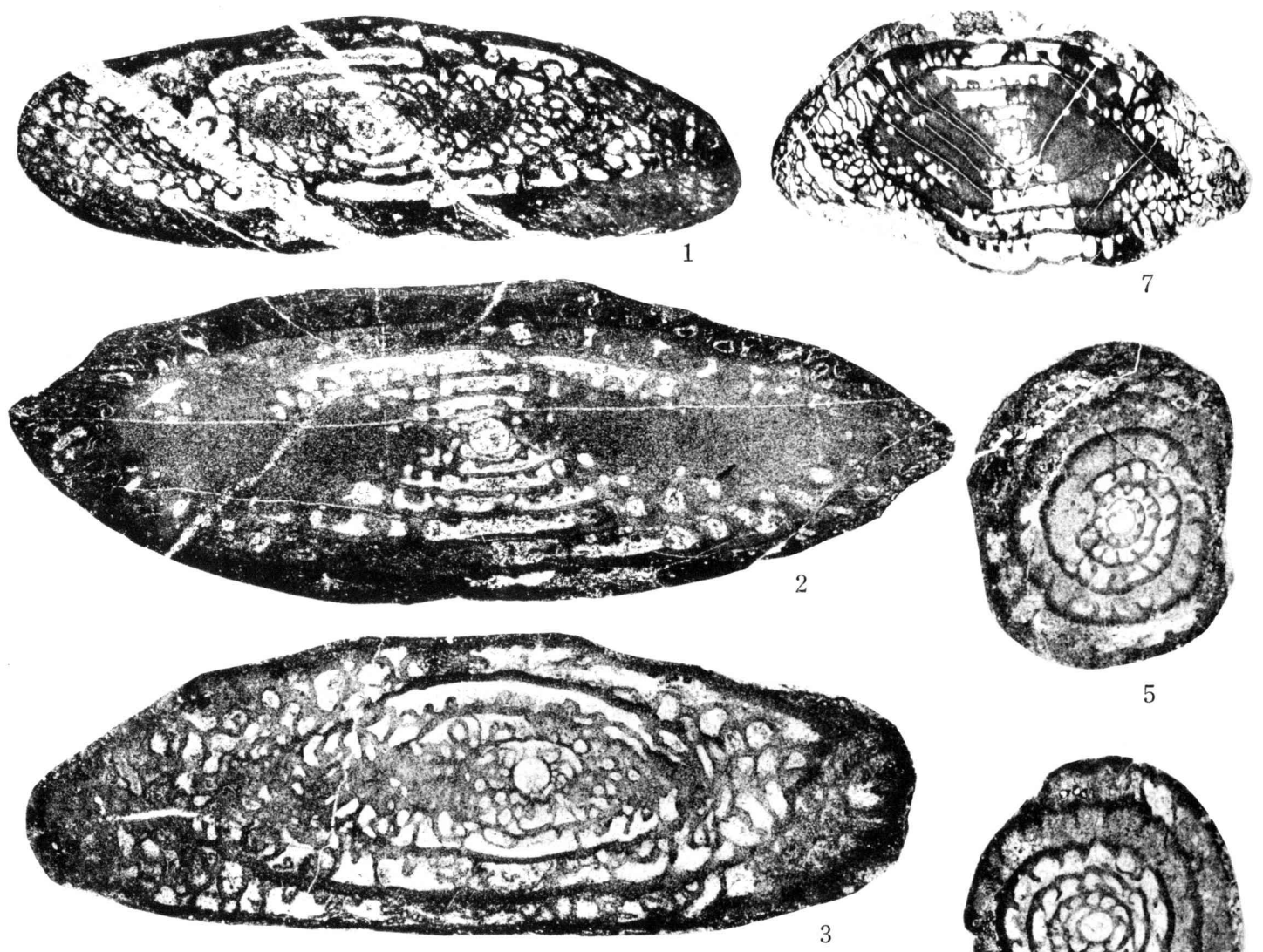

5
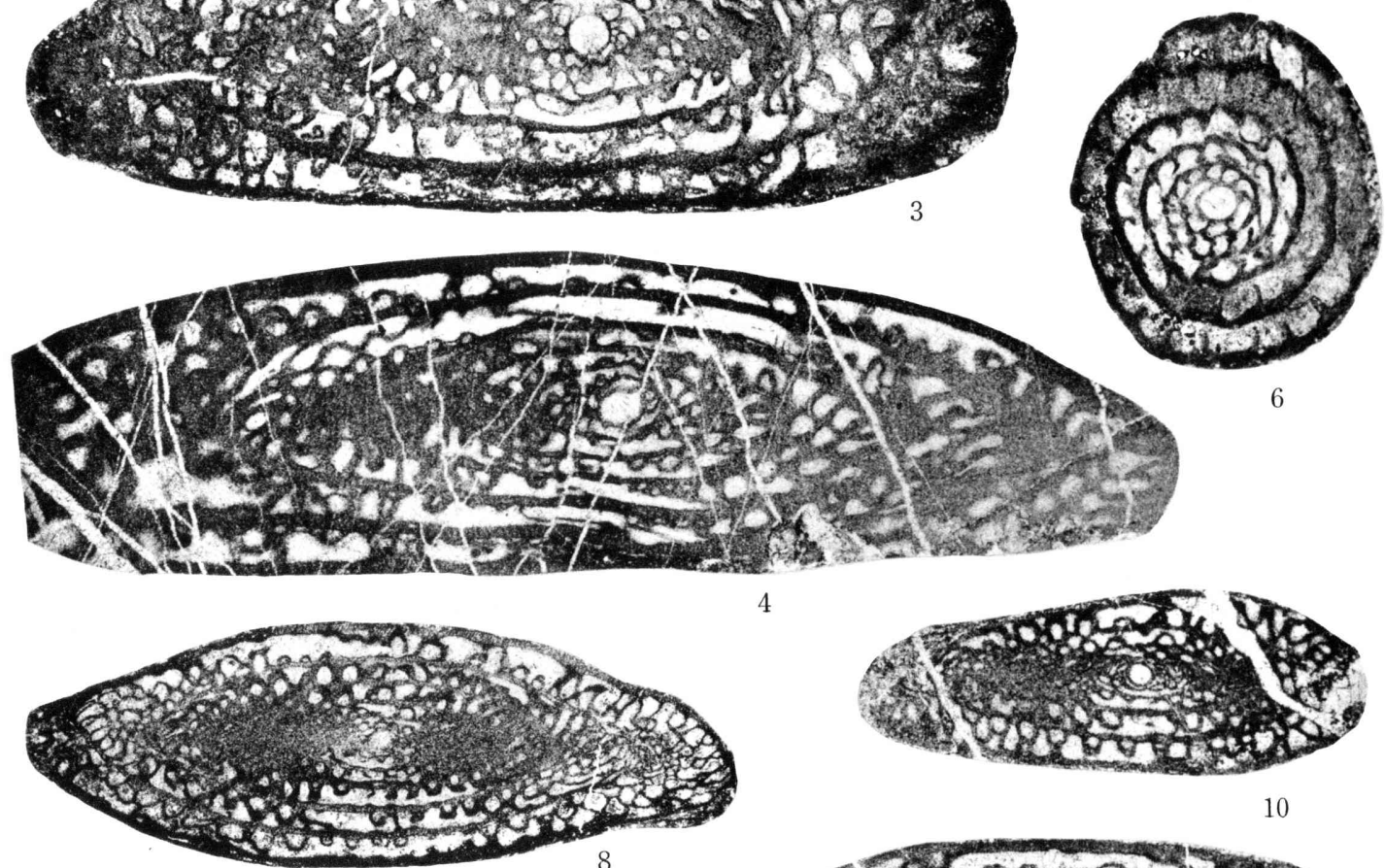

10
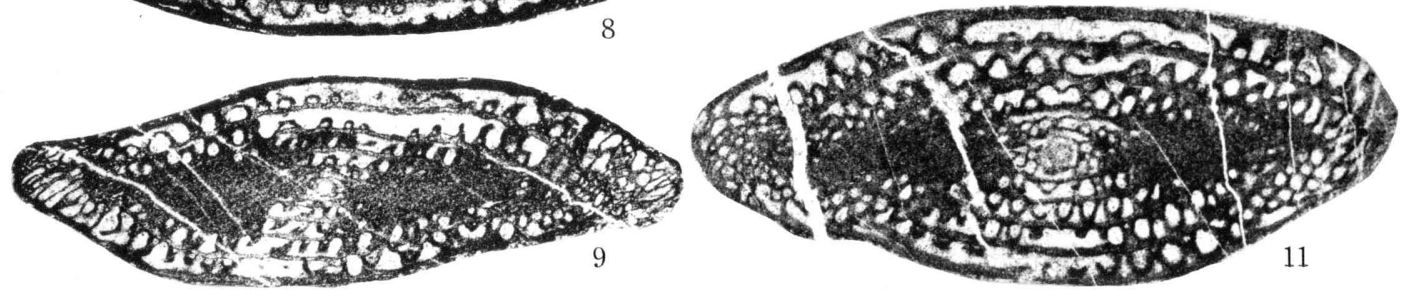

Kanmera and Mikami: The Sakamotozawan fusulinaceans 
Plate 53 


\section{Explanation of Plate 53}

All figures are $\times 10$

Figs. 1-6. Pseudofusulina sp. aff. P. japonica (GüMBEL)

1, Slightly diagonal axial section, GK. D 12548a ; 2, incomplete axial section, GK. D 12593 ; 3, tangential section crossing the outer end of the proloculus, GK. D 12549 ; 4, tangential section, GK.D 12547a; 5, 6, sagittal sections, slightly deformed, GK. D 12587a and $12587 \mathrm{~b}$, respectively. $1,3-6$ are from loc. Ks $29 ; 2$ from loc. Ks 36 .

Figs. 7-9. Nagatoella minatoi sp. nov.

7, Axial section of the holotype, GK. D $12718 ; 8,9$, tangential sections of paratypes, GK. D 12717a and $12714 \mathrm{a}$, respectively. All from loc. Ks 39 . 

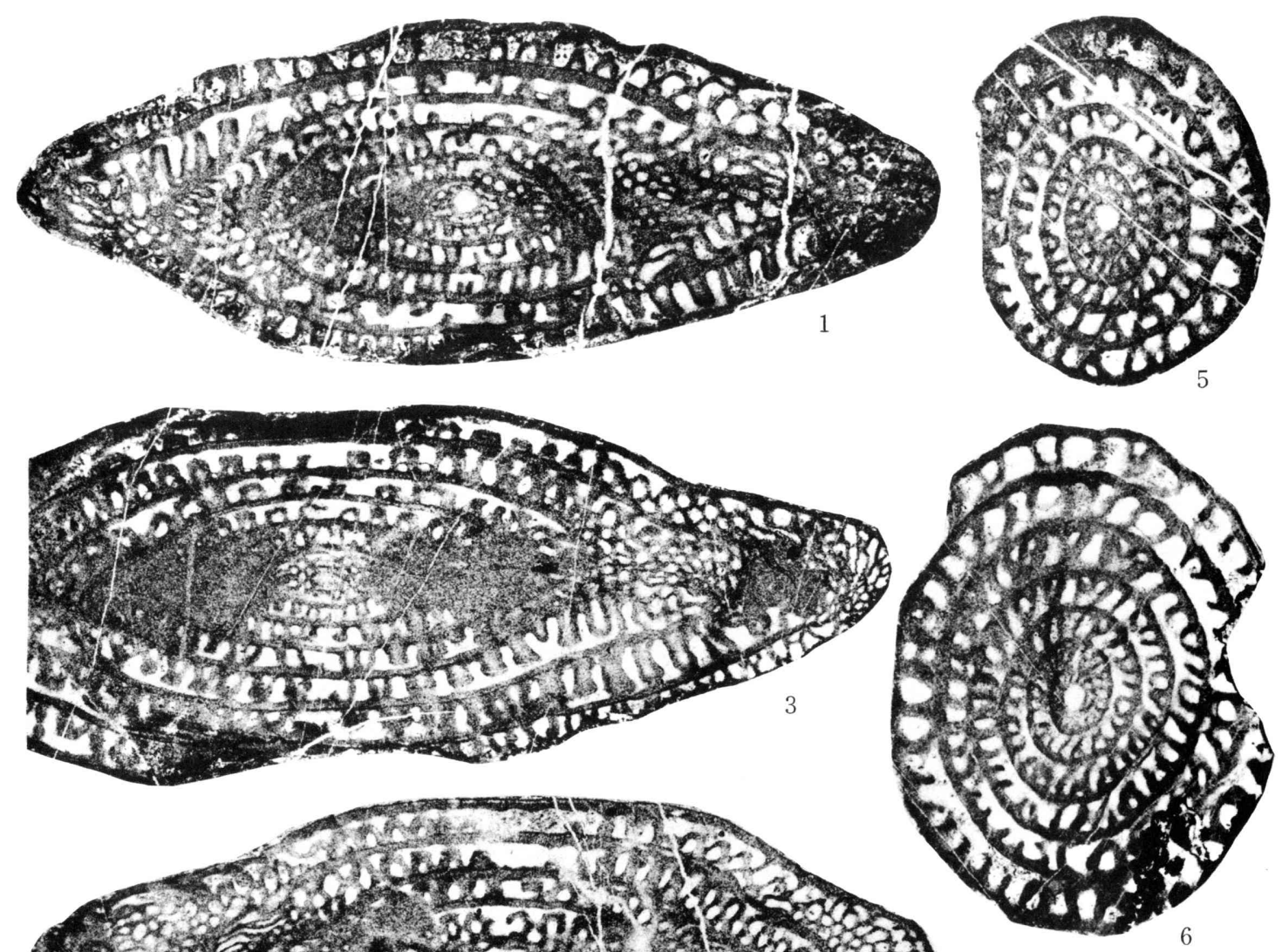

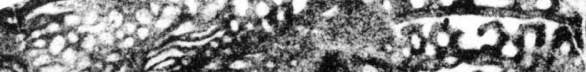

U.
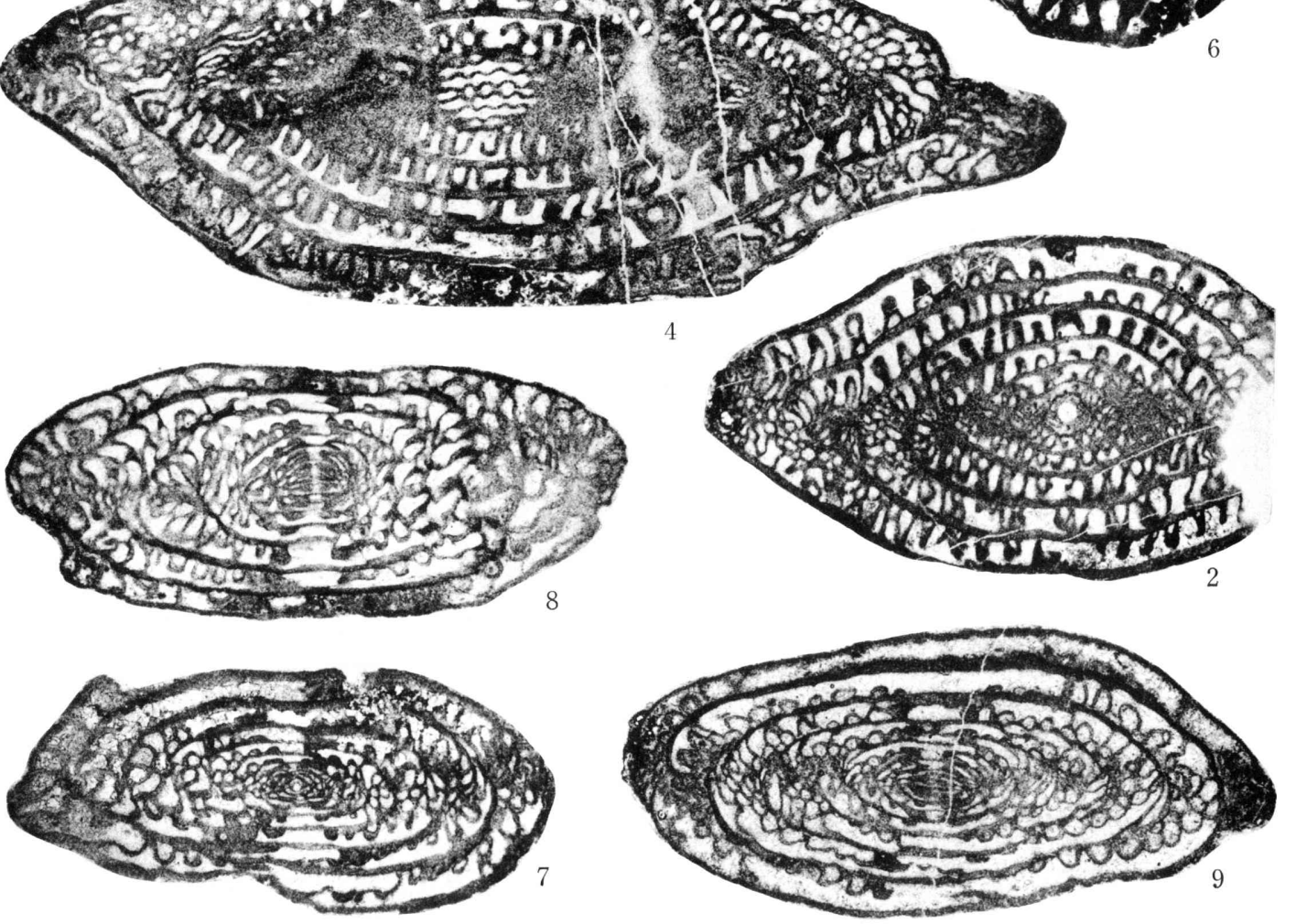

Kanmera and Mikami: The Sakamotozawan fusulinaceans 